\title{
REVISION OF GENERA OF THE DRAGONETS (PISCES : CALLIONYMIDAE)
}

AUTHOR(S):

Nakabo, Tetsuji

\section{CITATION:}

Nakabo, Tetsuji. REVISION OF GENERA OF THE DRAGONETS (PISCES : CALLIONYMIDAE). PUBLICATIONS OF THE SETO MARINE BIOLOGICAL LABORATORY 1982, 27(1-3): 77-131

ISSUE DATE:

1982-03-30

URL:

http://hdl.handle.net/2433/176044

RIGHT: 


\title{
REVISION OF GENERA OF THE DRAGONETS (PISGES: GALLIONYMIDAE)
}

\author{
Tetsuji NAKABO \\ Department of Fisheries, Faculty of Agriculture, Kyoto University
}

With Text-figures $1-30$ and Tables 1-2

\begin{abstract}
The fishes of this family Callionymidae are classified into 19 genera. The twelve genera are redifined and the other seven genera are established as new. A key to the genera is given. The habitat and geographic distribution of each genus are shown. The external characters, especially cephalic lateral lines, lateral lines on the body, body size, body form, body color, eye diameter and secondary sexual characters, are discussed in relation to the systematics of this family.
\end{abstract}

\section{Introduction}

Since Linnaeus (1758) first established the genus Callionymus, the classification of this family has been revised several times. Gill (1860) was the first to divide Callionymus into three genera, Callionymus, Synchiropus and Dactylopus. The Callionymidae was then studied by Bleeker (1879), Jordan and Fowler (1903), McCulloch (1926), Ninni (1934), Fowler (1914), Schultz and Woods (1948), de Beaufort (1951), Ochiai et al. (1955); Schultz (1960), Smith (1963), Mees (1963), Davis (1966), Johnson (1971), Fricke (1980) and Fricke (1981c). Because the callionymids show remarkable sexual dimorphism, the identification of the specimens belonging to this family has constrained much difficulty. Thus, taxonomic studies on the Callionymidae remain insufficient; the genera have not been defined adequately, probably because most investigators did not observe the internal characters of the specimens, and most fishes studied were taken only from their local waters.

In the present study, the confused classification of the Callionymidae is examined and its genera are reviewed on the basis of specimens from almost all part of the world. The habitat and geographic distribution of each genus are also described. The congeneric species are found to occupy roughly the similar kind of habitat, which supports the generic status ecologically. The geographic distribution of each genus tells us one of the aspects in the evolutionary history. Osteologically, each of the genera retained in this study is also distinguished from others (Nakabo, unpublished).

I here propose a new classification for the Callionymidae, which includes 19 genera encompassing 7 new ones, and 139 valid species (Table 1). I could not classify the following 8 species because of insufficient information about them:

Publ. Seto Mar. Biol. Lab., XXVII (1/3), 77-131, 1982.

(Article 5) 
Callionymus orientalis Bloch and Schneider (1801), Callionymus achates De Vis (1883), Callionymus caeruleonotatus Gilbert (1905), Callionymus inversicoloratus Seale (1909), Synchiropus zamboangana Seale (1909), Callionymus wilburi Here (1935), Callionymus mortenseni Suwardji (1965) and Callionymus sausai Maul (1972). Therefore, I have excluded them from the present list.

\section{Materials and Methods}

The specimens used for making the generic revision of the Callionymidae are shown in Table 1. These specimens have been preserved in $10 \%$ formalin, $70 \%$ ethyl alcohol or $40 \%$ isopropyl alcohol and are deposited at the following institutions: Australian Museum, Sydney; Academy of Natural Sciences of Philadelphia; British Museum (Natural History), London; California Academy of Sciences, San Francisco; Department of Biology, Faculty of Sciences, Kochi University; Department of Biology, University of the Ryukyus; Department of Fisheries, Faculty of Agriculture, Kyoto University; Department of Zoology, University Museum, University of Tokyo; Fisheries Research Station, Kyoto University; Far Seas Fisheries Research Laboratory; Laboratory of Marine Zoology, Faculty of Fisheries, Hokkaido University; Marine Science Museum, Tokai University; Museum of Tokyo University of Fisheries; Miyazaki University; Naturhistorisches Museum Wien; Department of Zoology, Natural Science Museum, Tokyo; Queensland Museum, Brisbane; J.L.B. Smith Institute of Ichthyology, Rhodes University, Grahamstown; Sammlung

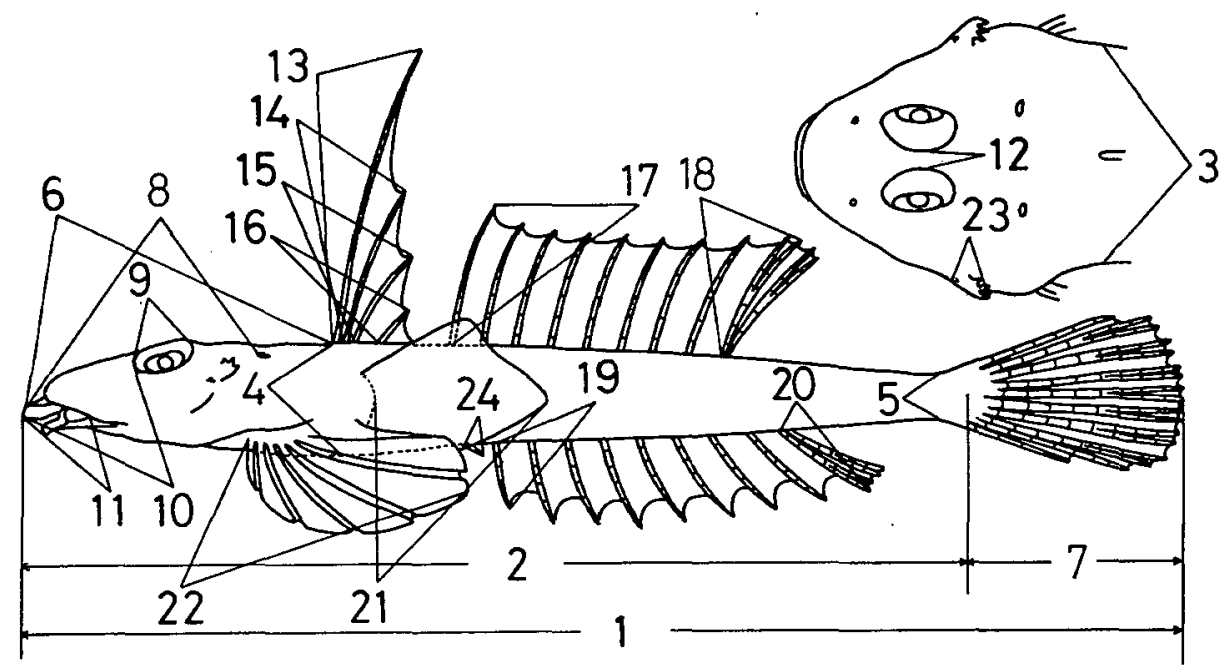

Fig. 1. Diagrammatic illustration showing the measuring methods of the portions of callionymid body. 1, total length; 2, standard length; 3 body width; 4, body depth; 5, caudal peduncle depth; 6, predorsal length; 7, caudal fin length; 8 , head length; 9, eye diameter; 10, snout length; 11, upper jaw length; 12, interorbital width; 13, 1st dorsal spine length; 14, 2nd dorsal spine length; 15, 3rd dorsal spine length; 16 , 4th dorsal spine length; 17, 1st dorsal ray length; 18, last dorsal ray length; 19 , 1st anal ray length; 20, last anal ray length; 21, pectoral fin length; 22, pelvic fin length; 23, preopercular spine length; 24, anal papilla length 
Table 1. Callionymid genera and species arranged in conformity with the new scheme, and specimens examined during the revision of the genera.

\begin{tabular}{|c|c|c|}
\hline Genera and species & $\begin{array}{l}\text { Number of } \\
\text { specimens }\end{array}$ & $\begin{array}{l}\text { Standard } \\
\text { length } \\
(\mathbf{m m})\end{array}$ \\
\hline \multicolumn{3}{|l|}{ Callionymus Linnaeus, 1758} \\
\hline C. lyra Linnaeus, 1758 & 11 & $124.6-178.5$ \\
\hline C. pusillus Delaroche, 1809 & 6 & $28.8-80.4$ \\
\hline C. maculatus Rafinesque, 1810 & 4 & $78.2-101.5$ \\
\hline C. risso LeSueur, 1814 & 3 & $39.9-47.4$ \\
\hline C. reticulatus Valenciennes, 1837 & 5 & $31.6-60.6$ \\
\hline \multicolumn{3}{|l|}{ Bathycallionymus n. g. } \\
\hline B. kaianus (Gunther, 1880) & 91 & $67.2-146.3$ \\
\hline \multicolumn{3}{|l|}{ *B. carebares (Alcock, 1890) } \\
\hline B. sokonumeri (Kamohara, 1936) & 21 & $53.0-140.1$ \\
\hline B. moretonensis (Johnson, 1971) & 11 & $74.7-148.0$ \\
\hline \multicolumn{3}{|l|}{${ }^{*} B$. kotthausi (Kotthaus, 1977) } \\
\hline \multicolumn{3}{|l|}{ *B. africanus (Kotthaus, 1977) } \\
\hline B. regani (Nakabo, 1979) & 11 & $114.5-157.5$ \\
\hline B. formosanus (Fricke, 1981) & 16 & $96.6-171.4$ \\
\hline \multicolumn{3}{|l|}{${ }^{*} B$. whiteheadi (Fricke, 1981) } \\
\hline \multicolumn{3}{|l|}{ *B. guentheri (Fricke, 1981) } \\
\hline \multicolumn{3}{|l|}{ *B. altipinnis (Fricke, 1981) } \\
\hline \multicolumn{3}{|l|}{ Foetorepus Whitley, 1931} \\
\hline F. calauropomus (Richardson, 1844) & 2 & $111.0-131.8$ \\
\hline F. altivelis (Temminck and Schlegel, 1845) & 55 & $55.2-185.7$ \\
\hline F. phaeton (Gunther, 1861) & 3 & $86.0-121.0$ \\
\hline F. phasis (Gunther, 1880) & 1 & 47.4 \\
\hline F. agassizi (Goode and Bean, 1888) & 1 & 62.1 \\
\hline F. atrilabiatus (Garman, 1899) & 1 & 27.4 \\
\hline \multicolumn{3}{|l|}{ *F. apricus (McCulloch, 1926) } \\
\hline F. monacanthus (Smith, 1936) & 1 & 101.2 \\
\hline \multicolumn{3}{|l|}{ *F. bicornis (Norman, 1939) } \\
\hline \multicolumn{3}{|l|}{${ }^{*} F$. grinnelli (Fowler, 1941) } \\
\hline F. delandi (Fowler, 1943) & 10 & $92.9-156.8$ \\
\hline F. sp. 1 (from the Emperor Seamounts) & 1 & 105.5 \\
\hline F. sp. 2 (Callionymus phasis of McCann, 1972) & 1 & 90.7 \\
\hline F. sp. 3 (from the western Atlantic) & 3 & $41.6-58.0$ \\
\hline F. sp. 4 (Callionymus corallinus of Kamohara, 1951) & 2 & $115.4-142.3$ \\
\hline \multicolumn{3}{|l|}{ Eocallionymus } \\
\hline E. papilio (Gunther, 1864) & 8 & $26.0-68.7$ \\
\hline \multicolumn{3}{|l|}{ Paracallionymis Barnard, 1927} \\
\hline$P$. costatus (Boulenger, 1898) & 2 & $38.0-46.1$ \\
\hline \multicolumn{3}{|l|}{ *P. fowleri Poll, 1949} \\
\hline \multicolumn{3}{|l|}{ Neosynchiropus n. g. } \\
\hline N. ocellatus (Pallas, 1770) & 46 & $9.6-78.7$ \\
\hline \multicolumn{3}{|l|}{${ }^{*} N$. marmoratus (Peters, 1855) } \\
\hline N. rubrovinctus (Gilbert, 1905) & 1 & 18.0 \\
\hline \multicolumn{3}{|l|}{${ }^{*} N$. sechellensis (Regan, 1908) } \\
\hline N. ijimai (Jordan and Thompson, 1914) & 9 & $48.0-77.3$ \\
\hline N. morrisoni (Schultz, 1960) & 2 & $30.8-43.2$ \\
\hline
\end{tabular}

*. Species not observed. 
Table 1. Continued.

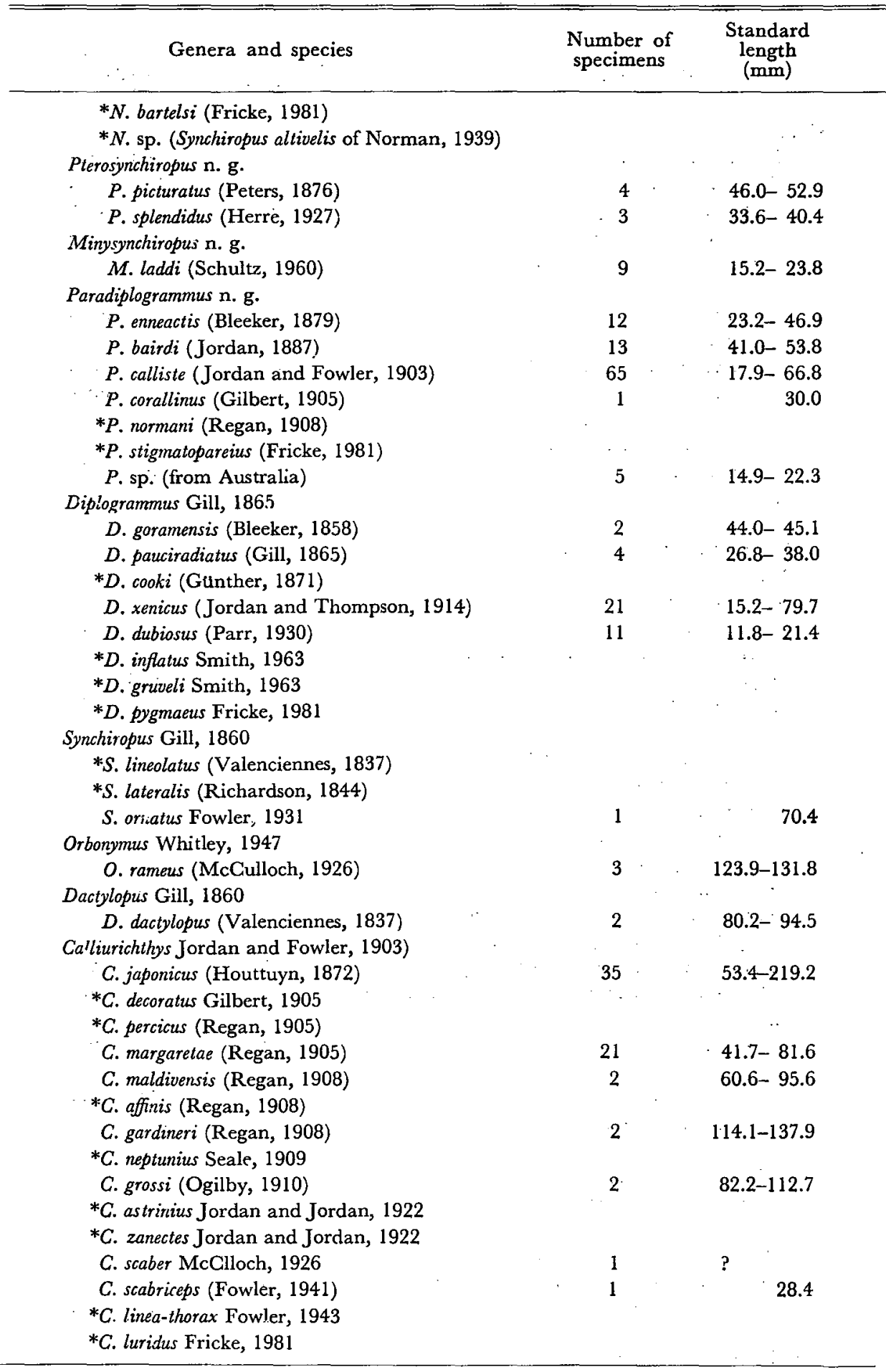


Table 1. Continued.

\begin{tabular}{|c|c|c|}
\hline Genera and species & $\begin{array}{l}\text { Number of } \\
\text { specimens }\end{array}$ & $\begin{array}{l}\text { Standard } \\
\text { length } \\
\text { (mm) }\end{array}$ \\
\hline \multicolumn{3}{|l|}{${ }^{*}$ C. sp. (Callionymus japonicus of Smith, 1963) } \\
\hline \multicolumn{3}{|l|}{ Pseudocalliurichthys $\mathrm{n} . \mathrm{g}$. } \\
\hline \multicolumn{3}{|l|}{ *P. simplicicornis (Valenciennes, 1837) } \\
\hline P. variegatus (Temrninck and Schlegcl, 1845) & 10 & $20.8-107.8$ \\
\hline P. xanthosemeion (Fowler, 1925) & 6 & $39.0-49.7$ \\
\hline \multicolumn{3}{|l|}{ *P. boleogenis (Fowler, 1941) } \\
\hline P. goodladi (Whitley, 1944) & 7 & $108.9-126.3$ \\
\hline \multicolumn{3}{|l|}{ *P. delicatulus (Smith, 1963) } \\
\hline \multicolumn{3}{|l|}{ *P. tenuis (Fricke, 1981) } \\
\hline \multicolumn{3}{|l|}{ Repomucenus Whitely, 1931} \\
\hline R. sagitta (Pallas, 1770) & 1 & 89.0 \\
\hline$* R$. serrato-spinosus (Gray, 1835) & & \\
\hline \multicolumn{3}{|l|}{$* R$. curvicornis (Valenciennes, 1837) } \\
\hline R. filamentosus (Valenciennes, 1837) & 12 & $27.5-114.2$ \\
\hline R. belcheri (Richardson, 1844) & 35 & $67.7-100.3$ \\
\hline \multicolumn{3}{|l|}{${ }^{*} R$. hindsii (Richardson, 1844) } \\
\hline R. valenciennei (Temminck and Schlegel, 1845) & 27 & $64.0-108.7$ \\
\hline R. lunatus (Temminck and Schlegel, 1845) & 46 & $43.6-156.3$ \\
\hline \multicolumn{3}{|l|}{ *R. melanotopterus (Bleeker, 1851) } \\
\hline R. schaapii (Bleeker, 1852) & 4 & $42.5-63.0$ \\
\hline R. richardsonii (Bleeker, 1854) & 61 & $59.9-174.3$ \\
\hline R. huguenini (Bleeker, 1859) & 45 & $52.0-184.0$ \\
\hline R. olidus (Gunther, 1873) & 2 & $33.5-36.8$ \\
\hline \multicolumn{3}{|l|}{${ }^{*}$ R. fluviatilis (Day, 1875) } \\
\hline R. calcaratus (Macleay, 1881) & 7 & $102.4-158.4$ \\
\hline R. beniteguri (Jordan and Snyder, 1900) & 98 & $58.2-160.5$ \\
\hline$R$. virgis (Jordan and Fowler, 1903) & 51 & $21.2-81.4$ \\
\hline R. ornatipinnis (Regan, 1905) & 89 & $72.1-171.4$ \\
\hline R. limiceps (Ogilby, 1908) & 14 & $89.0-154.8$ \\
\hline \multicolumn{3}{|l|}{${ }^{*} R$. cooperi (Regan, 1908) } \\
\hline R. macdonaldi (Ogilby, 1911) & 15 & $40.6-83.3$ \\
\hline R. marleyi (Regan, 1919) & 2 & $39.9-43.8$ \\
\hline R. sublaevis (McCulloch, 1926) & 4 & $95.9-120.4$ \\
\hline \multicolumn{3}{|l|}{$* R$. erythraeus (Ninni, 1934) } \\
\hline R. timbrithorax (Fowler, 1941) & 1 & 28.8 \\
\hline R. marisinensis (Fowler, 1941) & 1 & 37.4 \\
\hline R. longi (Fowler, 1941) & 1 & 71.4 \\
\hline R. brunneus (Fowler, 1941) & 7 & $51.6-61.8$ \\
\hline R. punctilateralis (Fowler, 1941) & 4 & $39.3-59.1$ \\
\hline \multicolumn{3}{|l|}{${ }^{*} R$. keeleyi (Fowler, 1941) } \\
\hline R. leucobranchialis (Fowler, 1941) & 10 & $28.1-50.3$ \\
\hline R. planus (Ochiai, 1955) & 43 & 23.4-102.1 \\
\hline \multicolumn{3}{|l|}{${ }^{*} R$. meridionalis (Suwardji, 1965) } \\
\hline \multicolumn{3}{|l|}{${ }^{*} R$. hainanensis $(\mathrm{Li}, 1966)$} \\
\hline \multicolumn{3}{|l|}{${ }^{*} R$. bali (Suwardji, 1965) } \\
\hline R. russelli (Johnson, 1976) & 5 & $72.4-89.1$ \\
\hline R. sp. 1 (from Panay, the Philippines) & 5 & $46.7-68.8$ \\
\hline R. sp. 2 (from Manira, the Philippines) & 3 & $30.3-55.0$ \\
\hline
\end{tabular}


Table 1. Continued.

\begin{tabular}{|c|c|c|}
\hline Genera and species & $\begin{array}{l}\text { Number of } \\
\text { specimens }\end{array}$ & $\begin{array}{l}\text { Standard } \\
\text { length } \\
(\mathrm{mm})\end{array}$ \\
\hline$R$. sp. 3 (from Australia) & 14 & $68.3-113.6$ \\
\hline \multicolumn{3}{|l|}{ Spinicapitichthys Fricke, 1980} \\
\hline \multicolumn{3}{|l|}{ *S. muscatensis (Regan, 1905) } \\
\hline S. spiniceps (Regan, 1908) & 10 & $86.4-100.2$ \\
\hline S. draconis (Nakabo, 1977) & 1 & 93.8 \\
\hline \multicolumn{3}{|l|}{ *S. oxycephalus Fricke, 1980} \\
\hline \multicolumn{3}{|l|}{ Anaora Gray, 1835} \\
\hline A. tentaculata Gray, 1835 & 15 & $19.0-38.5$ \\
\hline \multicolumn{3}{|l|}{ *A. fowleri (Herre, 1928) } \\
\hline \multicolumn{3}{|l|}{ Eleutherochir Bleeker, 1879} \\
\hline E. opercularis (Valenciennes, 1837) & 2 & $19.7-66.3$ \\
\hline E. mirabilis (Snyder, 1911) & 33 & $37.5-54.1$ \\
\hline \multicolumn{3}{|l|}{${ }^{*}$ E. mccaddeni (Fowler, 1941) } \\
\hline \multicolumn{3}{|l|}{ *E. pogognathus (Gosline, 1959) } \\
\hline \multicolumn{3}{|l|}{${ }^{*}$ E. celetus (Smith, 1963) } \\
\hline *E. shango (Davis and Robins, 1966) & & \\
\hline
\end{tabular}

Fricke, Braunschweig; University of Michigan, Museum of Zoology; National Museum of the Smithsonian Institution; Western Australian Museum, Perth; and Yokosuka City Museum.

The methods that were used to measure body parts are shown in Fig. 1. The counting of fin rays follows the method of Hubbs and Lagler (1947). The lowermost pectoral rays were counted as having divided tips when it was impossible to recognize whether or not they were divided. Posteriormost tip of preopercular spine was not counted as upward process on the inner side. Proportional measurements of the genera are shown in Table 2.

The cephalic lateral line canals are observed by injecting black ink.

\section{Taxonomy}

\section{Family Callionymidae}

Body depressed. No scales on any part of body. Gill-opening small and oval, located on dorsal surface of posterior part of head. Preopercle with a retrorse strong spine. Upper jaw protractile downward (except Eleutherochir). A nostril on each side of preorbital region. Mouth small, protracted ventrally in most species. Teeth on both upper and lower jaws villiform in broad bands. Palatine and vomer toothless. Anal papilla conical, longer in males than in females. Lateral line canal well developed, single, reaching base of caudal fin or tip of a median caudal ray. Cephalic lateral line canal well developed; supraorbital canal single on interorbital space, bifurcating at preorbital region and opening before and after a nostril with a pore; anterior infraorbital canal placed above the posterior part of maxillary; posterior 
infraorbital canal extending forward below eye; supratemporal canal present; preoperculo-mandibular canal below preopercular spine opening with 5 pores. Most of lateral line canal raised from skin and surrounded by sensory cells and degenerate elliptical scales (Ochiai, 1963) which can be stained with alizarin Red-S. Anal papilla conical, longer in males than in females as primary sexual character.

Dorsal fin separated into 2 parts (rarely the first absent) : anterior composed of soft four spines, (rarely one or three), posterior of soft rays; dorsal rays unbranched except for the last. Pectoral fin large. Pelvic fin large and round, connected by a membrane to base of pectoral fin. Anal fin composed of soft rays; anal rays unbranched except for the last. Caudal fin with 10 rays.

Secondary sexual characters are remarkable in the adult male.

Key to the genera of the Callionymidae

A Upper edge of lower jaw with many fleshy papillae; mouth expanded laterally Eleutherochir (p. 109).

$\mathrm{A}_{2}$ Upper edge of lower jaw without fleshy papillae; mouth small and not expanded laterally.

$B_{1}$ A longitudinal dermal fold present on lower part of lateral side of body

Diplogrammus (p. 97).

$\mathrm{B}_{2} \quad$ No longitudinal dermal fold present on lower part of lateral side of body. $\mathrm{C}_{1}$ Tip of each dorsal ray bifurcate or multifurcate except last branched one.

$\mathrm{D}_{1}$ Tip of each dorsal ray multifurcate except last branched one.

Pterosynchiropus (p. 93).

$\mathrm{D}_{2} \quad$ Tip of each dorsal ray bifurcate except the last branched one.

$\mathrm{E}_{1}$ Pelvic spine and first pelvic ray fused to an elongate rod separated from the other pelvic rays....................................... Dactylopus (p. 101).

$\mathrm{E}_{2} \quad$ Pelvic spine and five rays connected by a membrane.

$\mathrm{F}_{1} \quad$ A transverse lateral line commissure on dorsal surface of caudal peduncle.

$\mathrm{G}_{1}$ Some long, transverse branches of lateral line canal present on dorsal surface of body ....................................Synchiropus (p. 98).

$\mathrm{G}_{2}$ No long, transverse branch of lateral line present on dorsal surface of body Eocallionymus (p. 89).

$\mathrm{F}_{2} \quad$ No transverse lateral line commissure on dorsal surface of caudal peduncle.

$\mathrm{H}_{1}$ Preopercular spine with 1 or 2 upward processes on inner side.

$I_{1}$ Tip of each branch of last anal ray simple..............Fotorepus (p. 87).

$\mathrm{I}_{2}$ Tip of each branch of last anal ray bifurcate...... Neosynchiropus (p. 92).

$\mathrm{H}_{2}$ Preopercular spine straight and elongate with an antrorse process at base, many short upward processes on inner side........... Orbonymus (p. 100).

$\mathrm{G}_{2} \quad$ Tip of each dorsal ray simple except last branched one.

$\mathrm{J}_{1}$ Preopercular spine simple without process; lateral line with many long, conspicuously transverse upward branches......Paracallionymus (p. 90).

$\mathrm{J}_{2}$ Preopercular spine with some processes. 
$\mathrm{K}_{\mathrm{I}}$ Preopercular spine with no antrorse process at base.

$L_{1}$ A transverse lateral line commissure present on dorsal surface of caudal peduncle ............................... Callionymus (p. 84).

$\mathrm{L}_{2} \quad$ No transverse lateral line commissure present on dorsal surface of caudal peduncle.

$\mathrm{M}_{1} 9$ dorsal and 8 anal rays Minysynchiropus (p. 94).

$\mathrm{M}_{2} 8$ dorsal and 7 anal rays Paradiplogrammus (p. 95).

$\mathrm{K}_{2}$ Preopercular spine with an antrorse process at base or with many processes on outer side.

$N_{1}$ Preopercular spine with several processes on outer and inner sides $\quad . . \ldots \ldots \ldots \ldots \ldots \ldots \ldots \ldots \ldots \ldots \ldots . . . \ldots \ldots$ Spinicapitichthys (p. 106).

$\mathrm{N}_{2}$ Preopercular spine with an antrorse process at base and one or many upward processes on inner side.

$\mathrm{O}_{1}$ No transverse lateral line commissure on dorsal surface of caudal peduncle.

$P_{1} \quad$ A pair of supraorbital cirri present .............Anaora (p. 108).

$\mathrm{P}_{2} \quad$ No supraorbital cirrus present.

$Q_{1}$ Preopercular spine straight with many short upward processes on the inner side.

$\mathrm{R}_{1} 9$ dorsal and 8 anal rays................Calliurichthys (p. 102).

$\mathrm{R}_{2} 8$ dorsal and 7 anal rays ........Pseudocalliurichthys (p. 104).

$Q_{2}$ Preopercular spine strongly curved upward at the posterior end, and with several upward processes on the inner side .................................Paradiplogrammus (p. 95).

$\mathrm{O}_{2} \quad \mathrm{~A}$ transverse lateral line commissure present on dorsal surface of caudal peduncle.

$\mathrm{S}_{1}$ Tips of one or two median caudal rays simple

$\mathrm{S}_{1} \quad$ Tips of 6 or 7 median caudal rays bifurcate.

Bathycallionymus (p. 86).

$\mathrm{T}_{1}$ Some long, or separated short transverse branches of lateral line canal present on dorsal surface of body.

$\mathrm{U}_{1}$ Preopercular spine short and slightly curved upward at the posterior end ...................Callionymus (p. 84).

$\mathrm{U}_{2}$ Preopercular spine elongate and straight with many short upward processes on the inner side. .Calliurichthys. (p. 102)

$\mathrm{T}_{2}$ Neither long, nor separated short transverse branch of lateral line canal present on dorsal surface of body......... Repomucenus (p. 105).

Genus Callionymus Linnaeus, 1758

(Figs. 2, 21A, 23, 24A, 29B.C)

Callionymus Linnaeus, 1758, Syst. Nat. ed. X, Vol. 1, p. 249 (type-species by original designation; Callionymus lyra). 
Description: D. III-IV, 6-10; A. 9; $\mathrm{P}_{1} . \mathrm{i}+16-20 ; \mathrm{P}_{2} . \mathrm{I}, 5 ;$ G. $\mathrm{i}+7+\mathrm{ii}$.

Body elongate and depressed. Gill-opening located midway between posterior edge of eye and upper origin of pectoral fin. Tip of upper jaw protruding anterior. Preopercular spine short, with an antrorse process at base and two upward processes on inner side; each process and posterior tip barbed (in C. risso and C. pusillus, without an antrorse process at base; each process and posterior tip not barbed). Infraorbital canal not extending below eye. Postocular commissure connected with preoperculo-mandibular canal, but in some species not connected; the latter above preopercular spine with a short retrorse branch (in C. risso and $C$. pusillus, the latter divided into 7-8 short parts). Lateral line reaching tip of a median caudal ray; the line of opposite side interconnected by a transverse branch across dorsal surface of caudal peduncle; several long transverse branches of lateral line on dorsal surface of body (in $C$. risso and $C$. pusillus, several separated short transverse branches there).

First dorsal fin beginning behind gill-opening. Dorsal and anal rays simple except last branched rays. Upper half of pectoral fin slightly emarginated, lower half rounded. Caudal fin rounded.

Color in preserved specimens. Body marbled brown above, white below. In C. lyra, body marbled sepia-brown above, white below.

SECONDARY SEXUAL DIMORPhism: In $C$. reticulatus and $C$. maculatus, the second

D

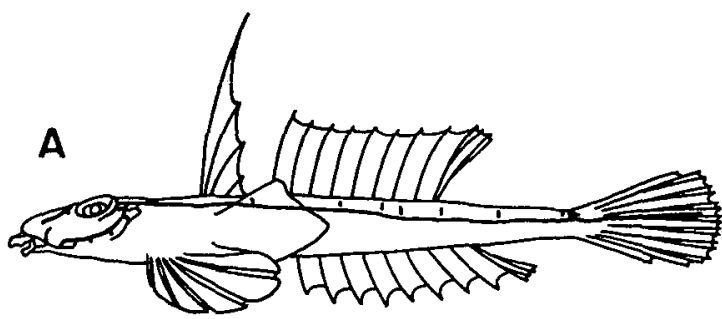

B
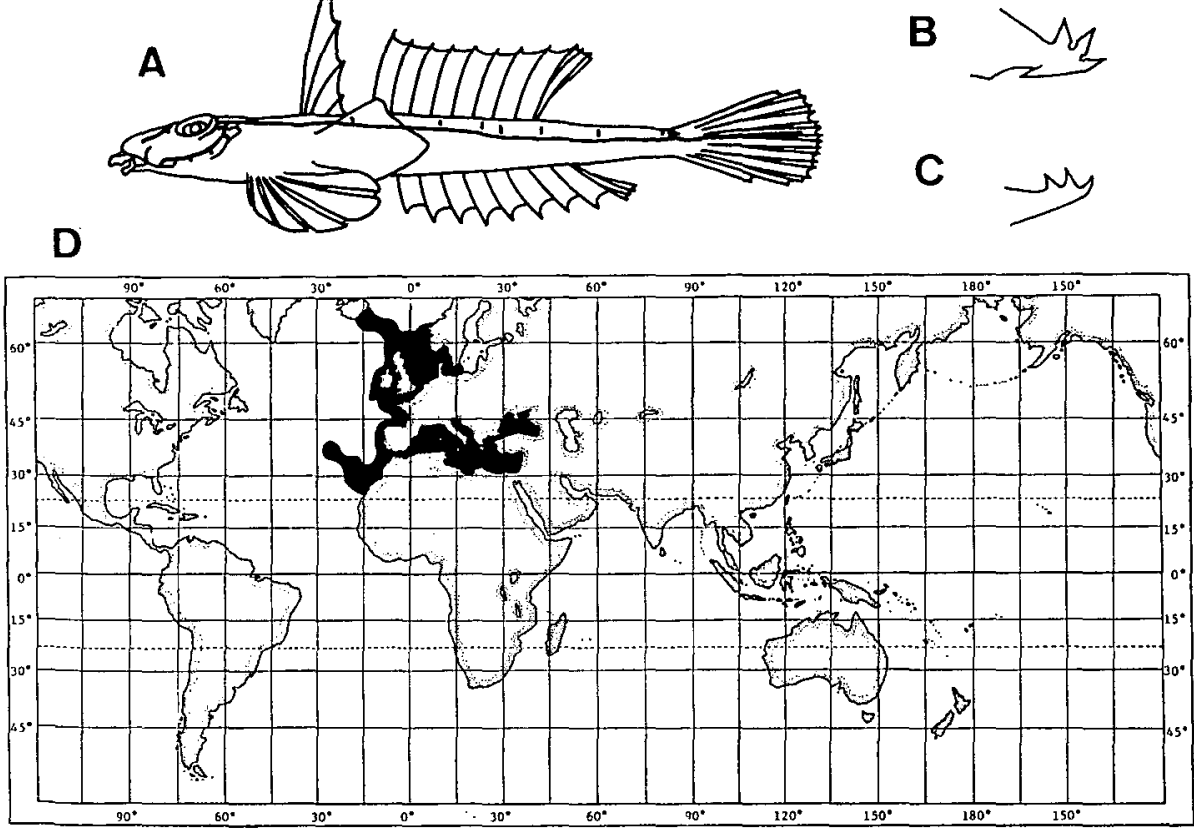

Fig. 2. Callionymus. A, lateral view of a C. lyra, male. Solid lines show the lateral line canals; B, preopercular spine of $G$. lyra; C, preopercular spine of $C$. risso; $\mathrm{D}$, geographic distribution of the genus. 
dorsal and anal fins of the male are remarkably large and are more colorful than those of the female.

HaBitat: Sandy-muddy bottoms in shallow to deep waters of the continental shelf, banks or seamounts.

GeOGRAPHIG Distribution: the northeastern Atlantic; the Mediterranean.

Remarks: Historically, the term Callionymus has been applied to most of the species belonging to the family Callionymidae. The results of this study show that the name, Callionymus should be limited to those five species distributed in the northeastern Atlantic and the Mediterranean.

Five species of this genus are divided into the following two groups in the preopercular spine and lateral line: C. lyra, C. reticulatus and $C$. maculatus; $C$. risso and $C$. pusillus. These two groups may be correspond to subgeneric status. The latter two species seem to be more specialized in the cephalic lateral line than the former three.

Callionymus (except $C$. risso and C. pusillus) is closely related to Bathycallionymus, both having the barbed process on the preopercular spine. Some species of these two genera are alike in their patterns of secondary sexual dimorphism.

\section{Genus Bathycallionymus n. g.}

(Figs. 3, 26A, 29G)

Bathycallionymus (type-species by original designation: Callionymus kaianus Gunther).

Description: D. IV, 9; A. 9; $\mathrm{P}_{1}$. $\mathrm{ii}+17-19 ; \mathrm{P}_{2}$. I, $5 ;$ C. $\mathrm{i}+3+\mathrm{ii}+2+\mathrm{ii}$ or $\mathrm{i}+3+\mathrm{i}+3+\mathrm{ii}$.

Body elongate and depressed. Eye very large. Interorbital space very narrow and concave. Gill-opening located midway between posterior edge of eye and upper origin of pectoral fin. Tip of upper jaw protruding anterior. Preopercular spine with an antrorse process at base and two upward processes on inner side; posterior upward process and posterior tip barbed. Infraorbital canal not extending below eye, with a long downward branch. Postocular commissure not connected to preoperculo-mandibular canal.

First dorsal fin beginning behind gill-opening. Tip of each dorsal ray, except last branched ray, simple. Upper half of pectoral fin slightly emarginated, lower half rounded. Tip of each anal ray simple. Tips of one or two median caudal rays simple.

Color in life. In B. regani, body sepia-brown above and below. But, in other species, body olive-brown above, white below.

Color in preserved specimens. Both sepia- and olive-brown colors somewhat darkened.

SEgondary SEXUAI DIMORPhism: In some species of this genus, the second dorsal and anal fins of the male are remarkably larger and are more colorful than in the female. 

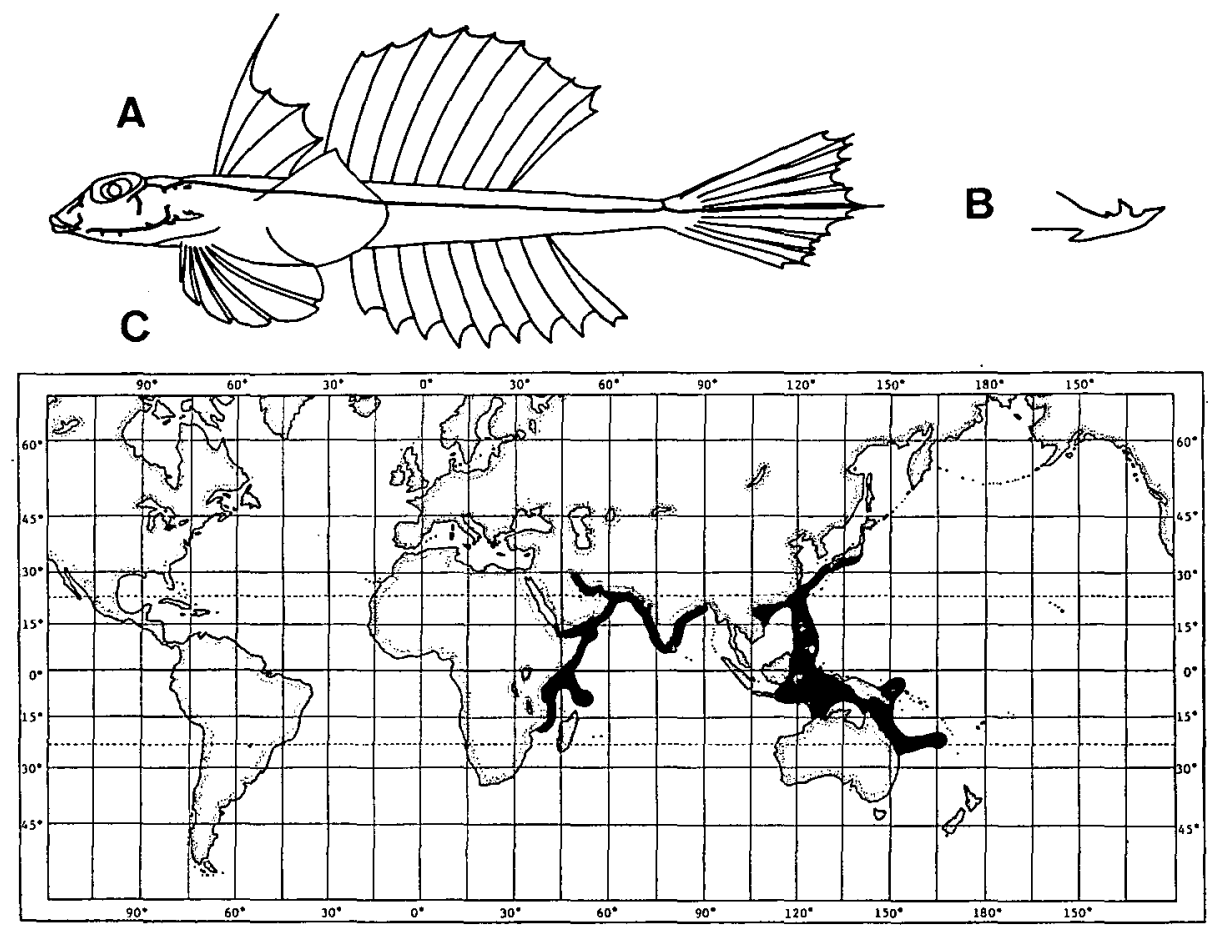

Fig. 3. Bathycallionymus. A, lateral view of a $B$. formosanus, male. Solid lines show the lateral line canals; B, preopercuiar spine of B. kaianus; C, geographic distribution of the genus.

Habitat: Sandy-muddy bottoms in deep waters near the edge of the continental shelf, banks or seamounts.

Geographic Distribution: northeastern coast of Africa; the Persian Gulf and western and eastern coasts of India; the western Pacific (Japan, the East China Sea, the South China Sea, New Guinea and north Australia).

Remarks: This new genus is closely related to Callionymus in its general physiognomy, especially the shape of the preopercular spine. It differs from the latter in having no commissure between the postocular commissure and the preoperculomandibular canal, no long transverse branches of the lateral line on the dorsal surface of the body and only one or two simple median caudal rays.

This new genus corresponds to the kaianus-group of the genus Callionymus described by Fricke (1981 e).

The generic name "Bathycallionymus" referrs to the genus living in deep waters near the edge of the continental shelf.

\section{Genus Foetorepus Whitley, 1931}

(Figs. 4, 21A, 29J)

Foetorepus Whitley, 1931a, Aust. Zool. 6, p. 323 (type-species by original designation: Callionymus calauropomus Richardson). 
Yerutius Whitley, 1931b, Rec. Aust. Mus. 18, p. 115 (type-species by original designation: Callionymus apricus McCulloch).

Description: D. IV, 8; A. 7; $\mathrm{P}_{1}$. i $+18-21$; P. I. 5; C. i+7+ii.

Body slightly depressed. Eye very large. Preopercular spine without an antrorse process at base, but with 1-2 upward processes on inner side; its posterior end pointed. Snout short; its tip located almost at anterior tip of upper jaw. Gillopening located somewhat behind middle between the posterior edge of eye and upper origin of pectoral fin. Infraorbital canal not extending below eye. Postocular commissure connected with preoperculo-mandibular canal; the latter above preopercular spine with a short retrorse branch. Lateral line of opposite side not interconnected on dorsal surface of caudal peduncle.
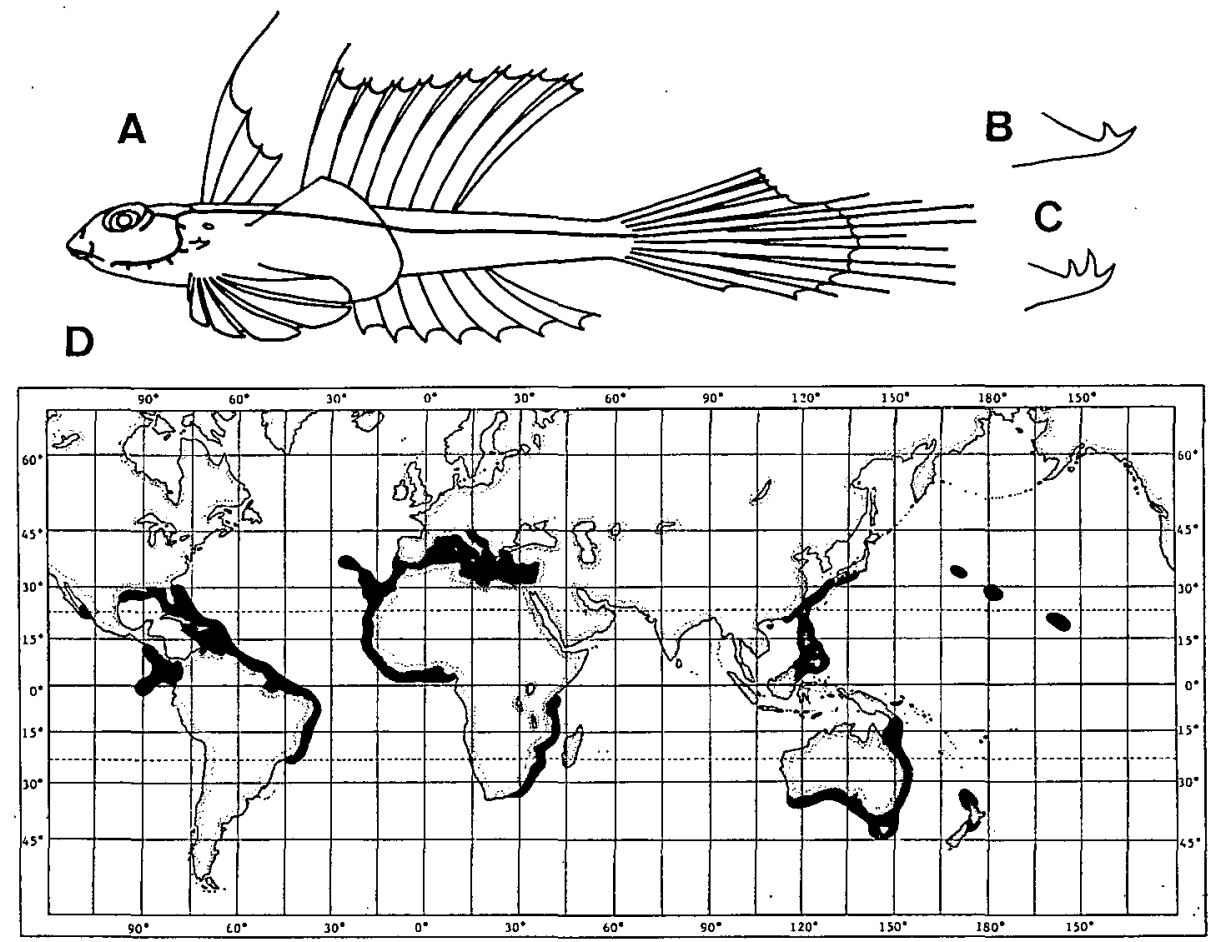

Fig. 4. Foetorepus. A, lateral view of a F. altivelis, male. Solid lines show the lateral line canals; B, preopercular spine of $F$. altivelis; C, preopercular spine of $F$. phaston; $\mathrm{D}$, geographic distribution of the genus.

First dorsal fin beginning just behind origin of pelvic fin. Tip of each dorsal ray, except posterior branch of last ray, bifurcate. Pectoral fin rounded. Tip of each anal ray simple. Caudal fin more elongate in males than in females, or lower half of caudal fin slightly filmanetous in some species.

Color in life. In most species, body reddish with unconspicuous olive-brown marks above, white below.

Color in preserved specimens. Reddish color faded to creamy white. In $F$. 
calauropumus, sepia-brown body above, white below.

SEcondary sexual Dimorphism: The second dorsal and caudal fins of the male are larger than those of the female. The lower caudal rays of the male in some species are filamentous.

Habitat: Sandy-muddy bottoms in deep waters near the edge of the continental shelf, and on banks or seamounts.

Geographic Distribution: Baja California; west coast of the Isthmus of Panama; middle part of the western Atlantic; middle part of the eastern Atlantic; the Mediterranean; coast of southeastern Africa; western Pacific (Japan, the Philippines, New Guinea and east and south Australia); New Zealand; the middle Pacific (Emperor Seamounts and the Hawaiis).

Remarks: Whitley (1931 a) established the genus Foetorepus on the basis of Callionymus calauropomus Richardson. Later (1931 b), he also established the genus Yerutius on the basis of Callionymus apricus McCulloch. Because these two fishes have common characters they can not be separated into two genera; they should belong to the prior genus, Foetorepus. Since Whitley (1931 a), did not define this genus sufficiently, Foetorepus has been redifined in this study.

The figure for the original description of the dorsal rays of $F$. calauropomus differ somewhat from the description of this genus. In the figure, the first dorsal ray is simple and the posterior branch of the last dorsal ray, bifurcate; whereas, for the specimens examined in this study and the specimen, $\mathrm{BM}(\mathrm{NH})$ 1855. 9. 19. 183 (A. Wheeler, personal communication), the former is bifurcate and the latter simple. The specimens used for this study do agree well in color pattern with the figure used for the original description. McGulloch (1926) first pointed out these variations. The other species of Foetorepus examined for this study did not have these variations. Their second dorsal fin is the same as the fin of specimens of $F$. calauropomus which I examined for this study. Therefore, I have adopted the above description for the second dorsal fin of Foetorepus.

\section{Genus Eocallionymus n. g.}

(Figs. 5, 21C, 29F)

Eocallionymus (type-species by original designation: Callionymus papilio Gunther).

Description: D. IV, 7; A. 6; $\mathrm{P}_{1} . \mathrm{i}+18-19 ; \mathrm{P}_{2}$. I, 5; C. $\mathrm{i}+7+\mathrm{ii}$.

Body slightly depressed. Eye moderately large. Preopercular spine without an antrorse process, but with an upward process on inner side, and its posterior tip curved dorsally. Snout short; its tip almost at tip of upper jaw. Gill-opening located midway between posterior edge of eye and upper origin of the pectoral fin. Infraorbital canal not extending below eye. Postocular commissure connected to the preoperculo-mandibular canal; the latter above preopercular spine with a short retrorse branch. Lateral line reaching tip of median caudal ray; the line of opposite side interconnected by a transverse branch across dorsal surface of caudal 

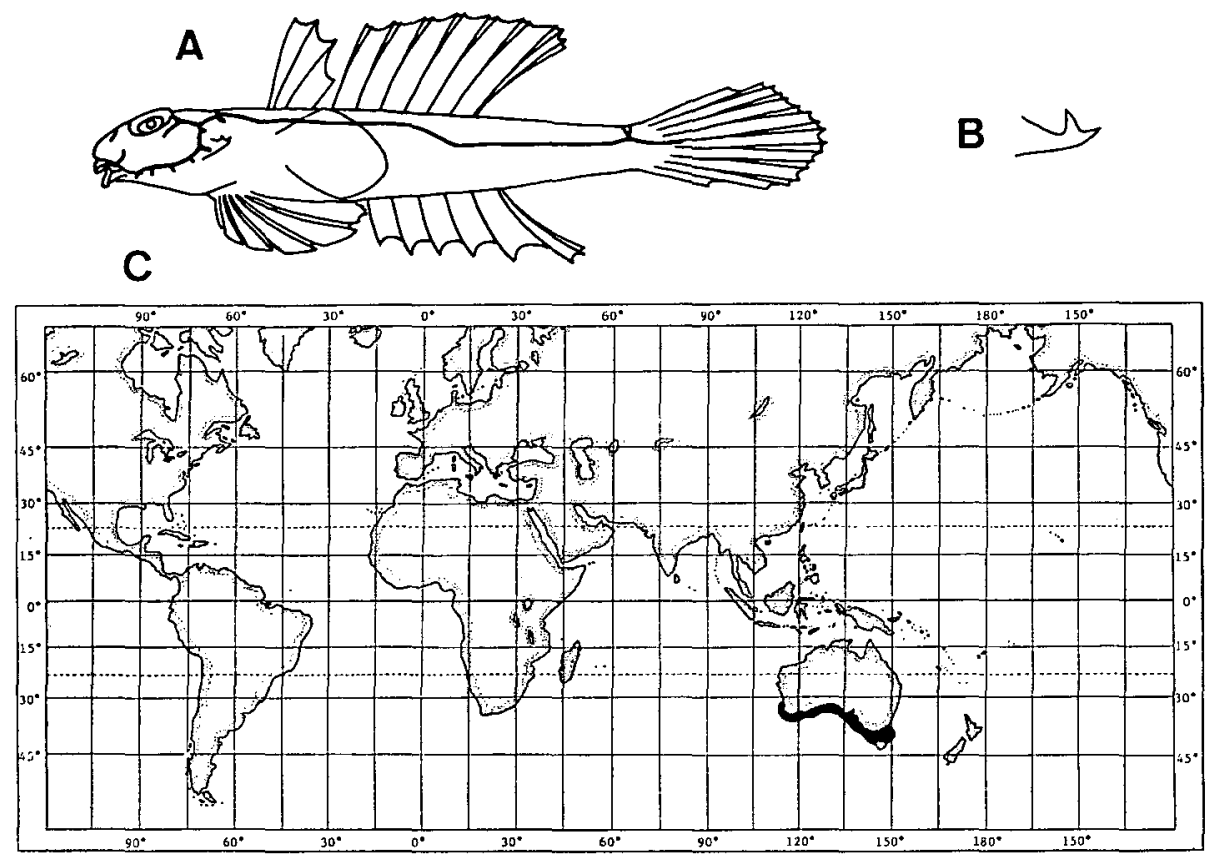

Fig. 5. Eocallionymus. A, lateral view of a E. papilio, male. Solid lines show the lateral line canals; B, preopercular spine of E. papilio; G, geographic distribution of the genus.

peduncle.

First dorsal fin small, and beginning almost at upper origin of pectoral fin. Tip of each dorsal ray bifurcate. Pectoral fin rounded. Tip of each anal ray simple.

Color in preserved specimens. Body marbled dark sepia-brown above, white below.

Secondary SEXUAL DIMORPHism: Fins of the male are slightly larger than those of the female. The color pattern of each unpaired fin is slightly more colorful in the male than in the female.

Habitat: Sandy bottoms with pebbles in shallow waters (D.F. Hoese, personal communication).

Geographic distribution: south coast of Australia.

Remarks: This new genus is much like Foetorepus and Neosynchiropus in its general physiognomy, especially the preopercular spine. One difference is the lateral line commissure on the dorsal surface of the caudal peduncle.

The generic name "Eocallionymus" means one of the earliest dragonet, because this genus has the most primitive osteological characters (Nakabo, unpublished).

Genus Paracallionymus Barnard, 1927

(Figs. 6, 26B, 29E)

Paracallionymus Barnard, 1927, Ann. South African Mus. 21, p. 448 (type-species by original designation: Callionymus costatus Boulenger). 
Description: D. IV, 9-10; A. 9; $\mathrm{P}_{1}$. i+18-19; $\mathrm{P}_{2}$. I, 5; C. $\mathrm{i}+7+\mathrm{ii}$.

Body elongate and depressed. Eye very large. Gill-opening located midway between posterior edge of eye and upper origin of pectoral fin. Upper jaw protruding anterior. Preopercular spine simple, only sharply pointed. Infraorbital canal bifurcate and not extending below eye. Postocular commissure not connected to preoperculo-mandibular canal. Lateral line reaching tip of median caudal ray, with many transverse branches upward and downward; upward branches long, with 4-5 short retrorse branches; the line of opposite side interconnected by a transverse branch across dorsal surface of caudal peduncle.
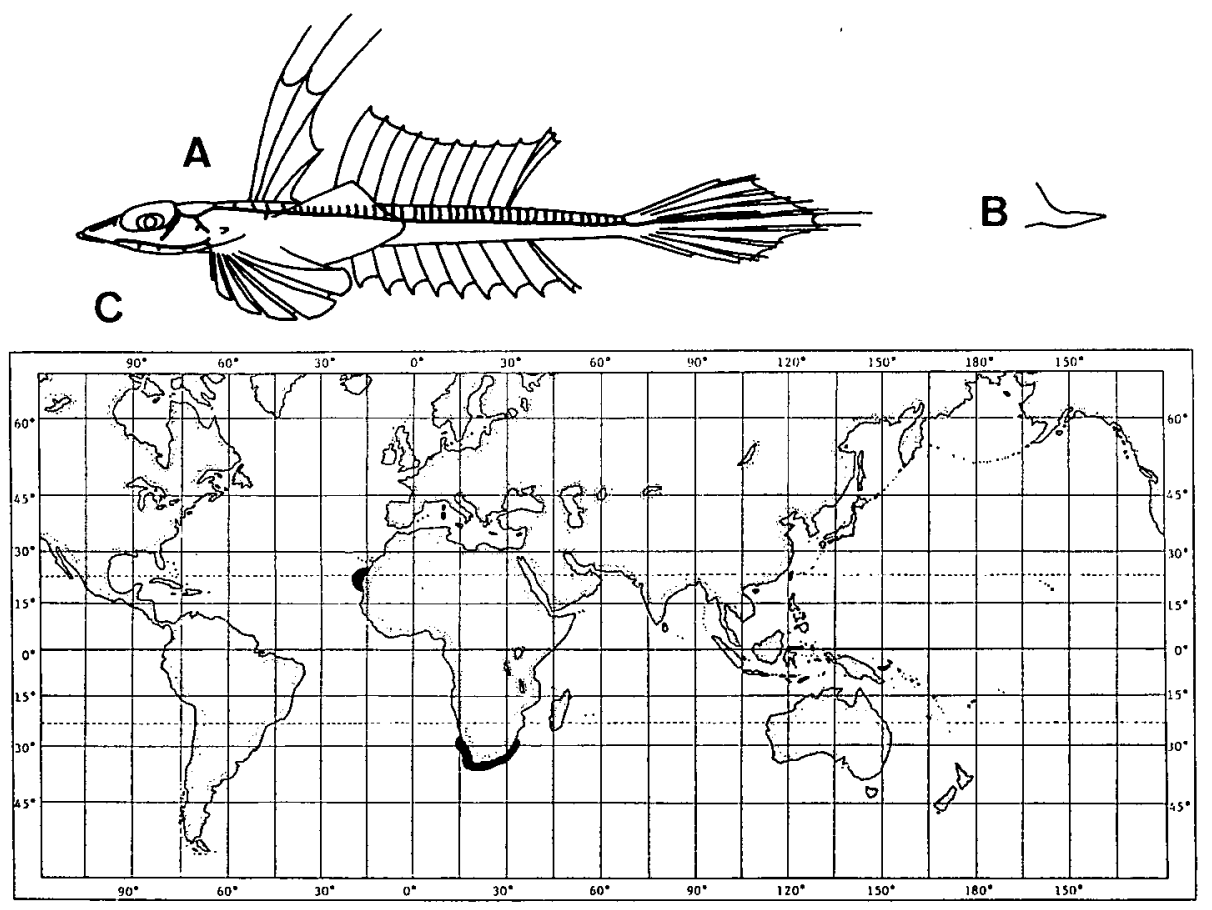

Fig. 6. Paracallionymus. A, lateral view of a $P$. costatus, male. Solid lines show the lateral line canals; $\mathrm{B}$, preopercular spine of $P$. costatis; $\mathrm{C}$, geographic distribution of the genus.

First dorsal fin beginning before upper origin of pectoral fin. Tips of each dorsal and anal ray, except last branched ray, simple. Pectoral fin lanceolate.

Color in preserved specimens. Body colorless.

Secondary SEXUAL Dimorphism: The first dorsal and caudal fins of the male are elongate (but, only the male observed).

Habitat: Sandy-muddy bottoms in deep waters (South Africa) and in shallow waters (Baie de Pulpito).

Geographic Distribution: South Africa; Rio de Oro, western Africa. 


\section{Genus Neosynchiropus n. g.}

(Figs. 7, 24B, 29J)

Neosynchiropus (type-species by original designation: Callionymus ocellatus Pallas).

Description: D. IV, 8; A. 7; $\mathrm{P}_{1}$. i+17-21, ii+17-19, iii+18; $\mathrm{P}_{2} . \mathrm{I}, 5 ; \mathrm{C}$. $\mathrm{i}+7+\mathrm{ii}$.

Body cylindrical. Eye moderately large. Gill-opening just behind middle between posterior edge of eye and upper origin of the pectoral fin. Tip of snout slightly anterior to tip of upper jaw. Preopercular spine with no antrorse process at base, and 1-2 upward processes on inner side; its posterior end pointed (in $N$. ijimae, with an antrorse process at base, and in $N$. sechellensis, with 1 or 2 small antrorse ones). Infraorbital canal not extending below eye. Postocular commissure not connected to preoperculo-mandibular canal. Lateral line reaching tip of median caudal ray; the line of opposite side not connected by a transverse branch on dorsal surface of caudal peduncle.

First dorsal fin beginning behind the gill-opening. Tip of each dorsal ray bifurcate. Pectoral fin rounded. Tip of each anal ray bifurcate in some species. Caudal fin rounded.
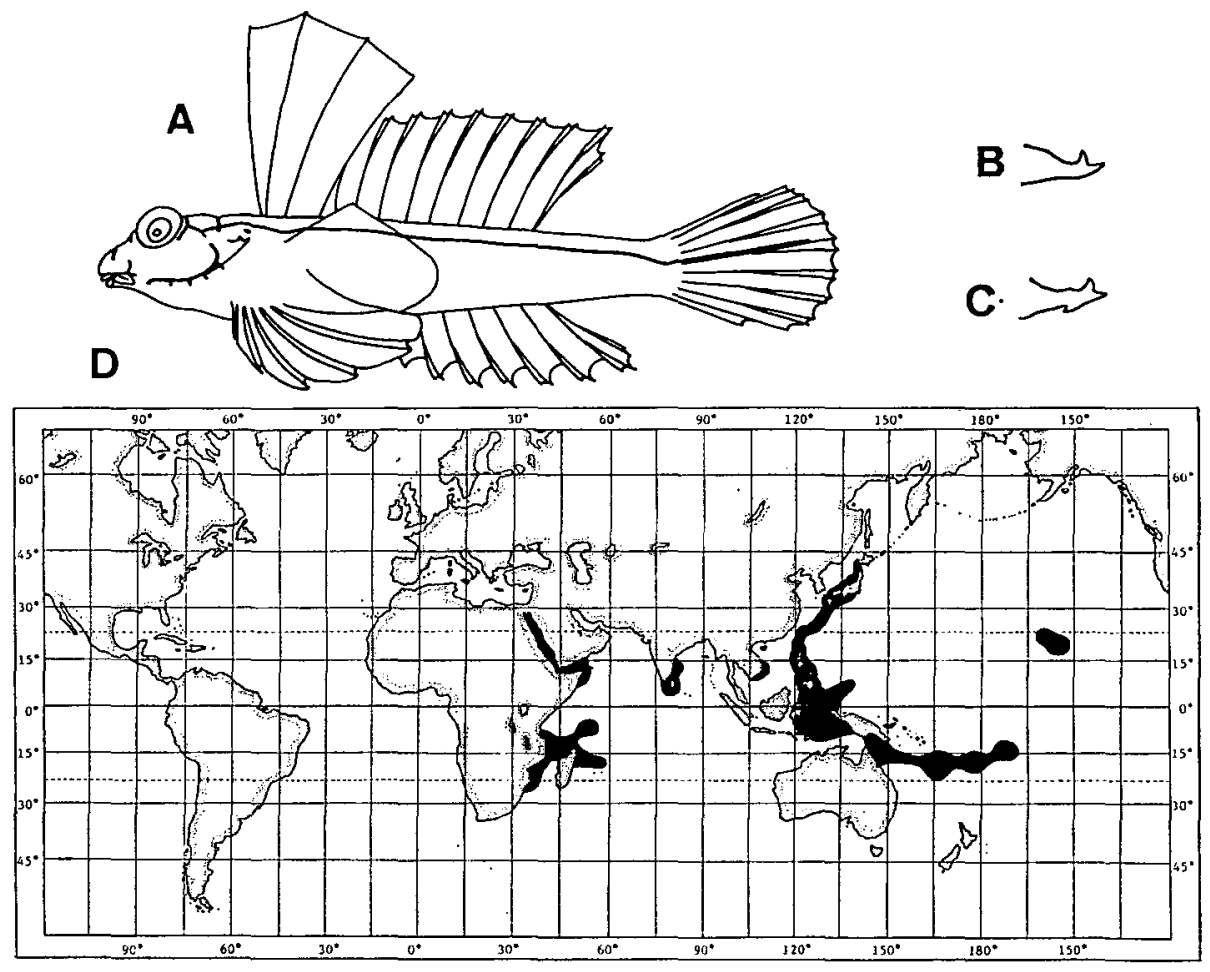

Fig. 7. Neosynchiropus. A, lateral view of a N. ocellatus, male. Solid lines show the lateral line canals; $\mathrm{B}$, preopercular spine of $N$. ocellatus; $\mathrm{C}$, preopercular spine of $N$. ijima $i$; $\mathrm{D}$, geographic distribution of the genus. 
Color in preserved specimens. Body marbled dark sepia-brown, white below.

SECONDARY SEXUAL DIMORPHISM: The male has a remarkably larger and more colorful first dorsal fin than the female.

Habitat: Sandy bottoms in coral reefs, tidal pools and weedy beds around islands.

Geographic Distribution: southeastern coast of Africa; east coast of India; the western Pacific; the Hawaiian Isls.

Remarks: This new genus is much like Synchiropus and Eocallionymus in its general physiognomy, especially body form and color pattern. It differs in having no lateral line commissure on the dorsal surface of the caudal peduncle.

\section{Genus Pterosynchiropus n. g.}

(Figs. 8, 24C, 29J)

Pterosynchiropus (type-species by original designation: Callionymus splendidus Herre).

Description: D. IV, 8; A. 7; $\mathrm{P}_{1}$. i $+29-30 ; \mathrm{P}_{2}$. I, 5; C. $\mathrm{j}+8+\mathrm{i}$.

Body cylindrical, posterior half slightly compressed. Eye large. Gill-opening just behind middle between posterior edge of eye and upper origin of pectoral fin. Tip of snout almost at tip of upper jaw. Preopercular spine with no antrorse process
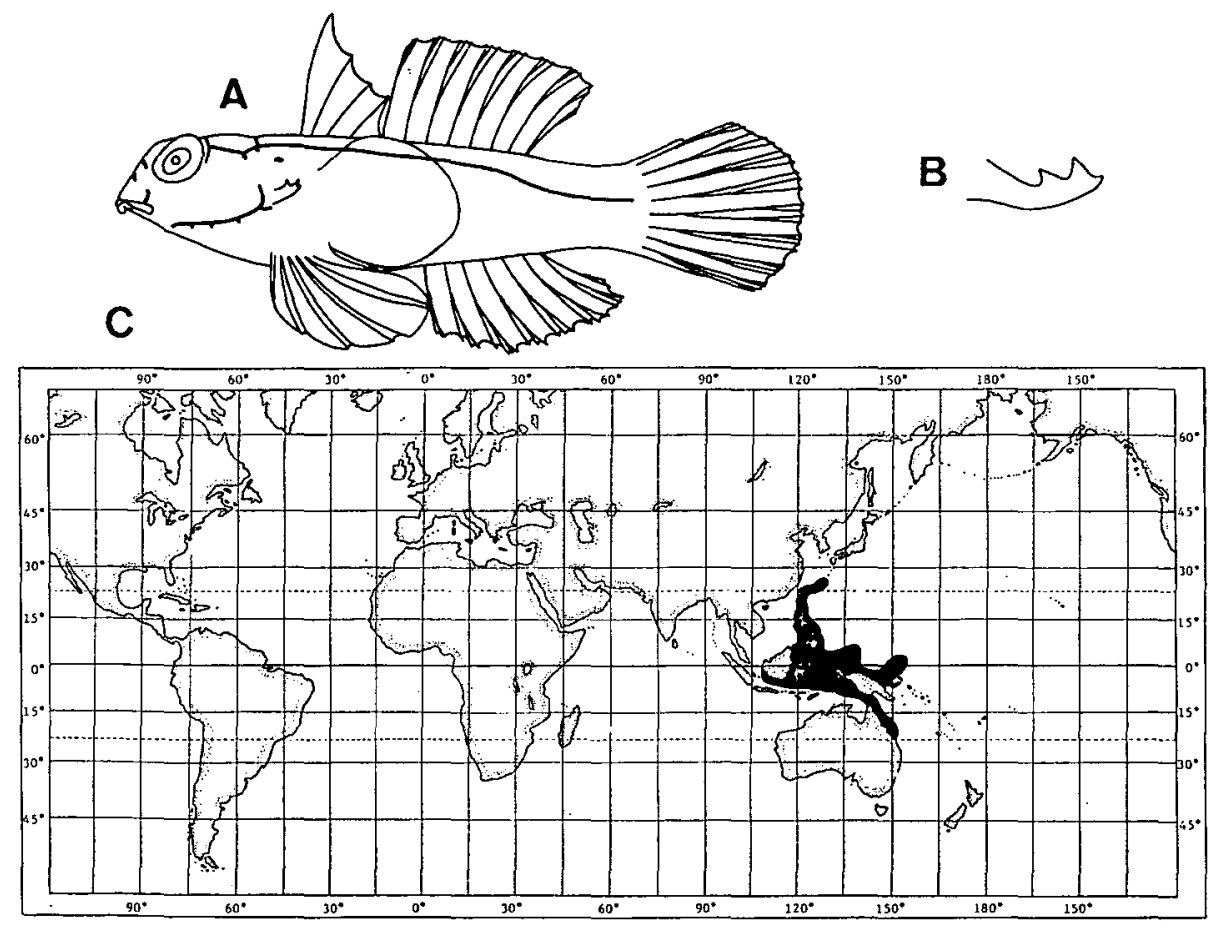

Fig. 8. Pterosynchiropus. A, lateral view of $P$. splendidus. Solid lines show the lateral line canals; B, preopercular spine of $P$. splendidus; C, geographic distribution of the genus. 
at base, 2-3 upward processes, posterior end curved upward. Caudal peduncle very compressed and deep. Infraorbital canal not extending below eye. Postocular commissure not connected to preoperculo-mandibular canal. Lateral line reaching base of caudal fin; the line of opposite side not connected by a transverse branch on dorsal surface of caudal peduncle.

First dorsal fin beginning behind gill-opening. Tip of each dorsal and anal ray multifurcate. Pectoral fin large and rounded, many more rays than in other genera. Membrane between pelvic fin and base of pectoral fin very narrow. Caudal fin rounded; median eight caudal fin rays multifurcate.

Color in preserved specimens. Body colorful.

Secondary sexual dimorphism: First dorsal spine is elongate and filamentous.

HABITAT: Coral reefs around islands.

Geographic Distribution: the Ryukyu Isls.; the Philippines; Great Barrier Reef.

Remarks: This new genus is very like Neosynchiropus in its general physiognomy, but differs in having multifurcate tips on its dorsal, anal and caudal rays, a compressed caudal peduncle and a broad pectoral fin with many rays.

Species belonging to this genus seem to swim among corals above the bottom as in the photograph in Wheeler (1975). The diagnostic characters of Pterosynchiropus must be related to their peculiar manner of swimming which is unique among callionymid fishes. Therefore, this genus has been named "Pterosynchiropus".

\section{Genus Minysynchiropus n. g.}

(Figs. 9, 21D, 29J)

Minysynchiropus (type-species by original designation: Synchiropus laddi Schultz).

Description: D. IV, 9; A. 8; $\mathrm{P}_{1}$. ii +16 , iii $+14-15$, iv $+13-14 ; \mathrm{P}_{2} . \mathrm{I}, 5 ; \mathrm{C}$. $\mathrm{i}+7+\mathrm{ii}$.

Body cylindrical. Eye large. Gill-opening just behind middle between posterior edge of eye and upper origin of pectoral fin. Tip of snout almost at tip of upper jaw. Preopercular spine with no antrorse process at base, many upward ones on inner side; posterior tip strongly curved upward. Infraorbital canal not extending below eye. Postocular commissure connected to preoperculo-mandibular canal, the latter above preopercular spine with a short retrorse branch. Lateral line reaching tip of a median caudal ray; line of opposite side not interconnected by transverse branch on dorsal surface of caudal peduncle.

First dorsal fin beginning just behind gill-opening. Tip of each dorsal ray, except last branched one, simple. Pectoral fin rounded. Tip of each anal ray simple. Caudal fin rounded.

Color in preserved specimens. Body almost creamy white with some inconspicuous, faintly dark marks.

SECONDARY SEXUAL DIMORPhism: First dorsal fin of the male is markedly larger 


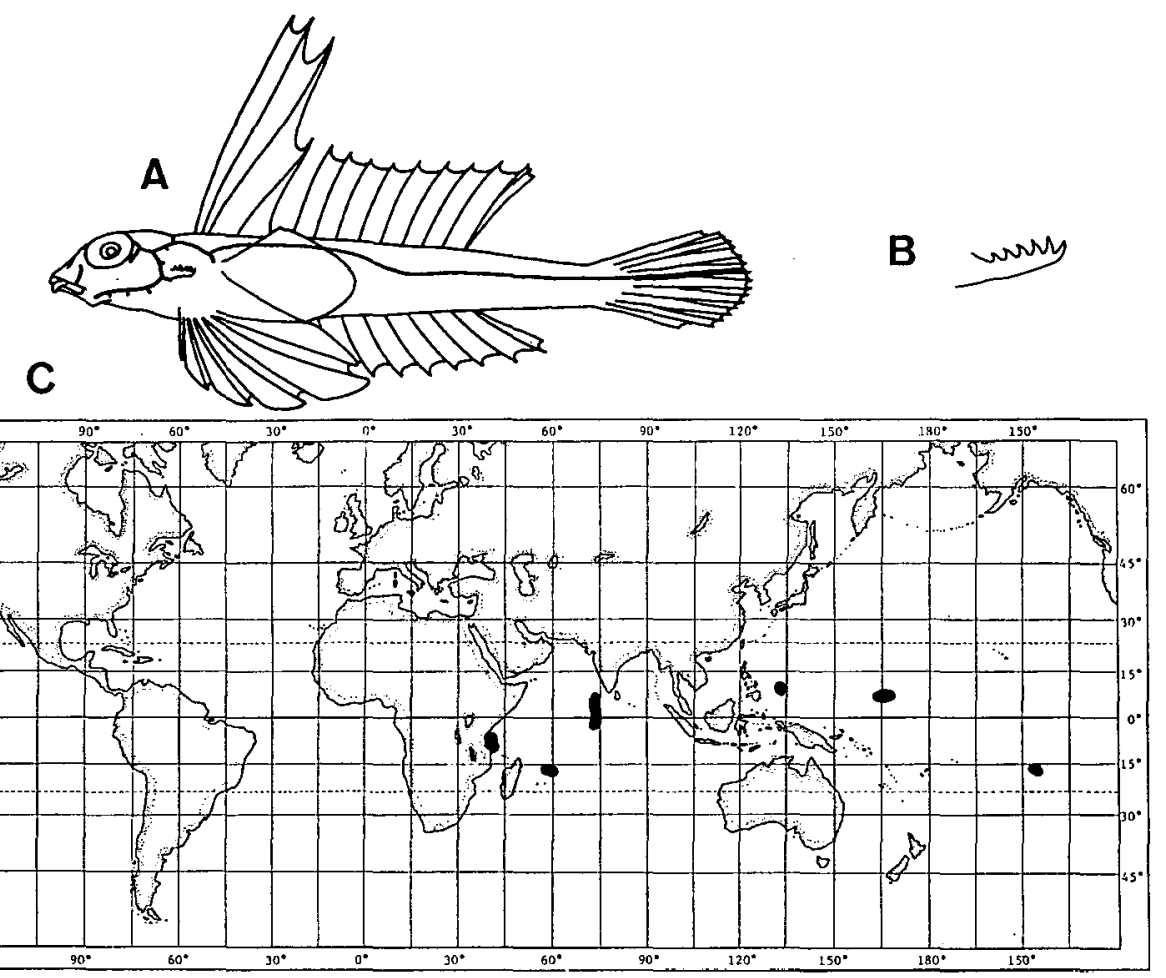

Fig. 9. Minysynchiropus. A, lateral view of a $M$. laddi, male. Solid lines show the lateral line canals; B, preopercular spine of $M$. laddi; $\mathrm{C}$, geographic distribution of the genus.

than that of the female.

Habitat: Sandy bottoms in tidal pools and coral reefs around islands.

Geographic Distribution: the Indian Ocean; the western and southern Pacific.

Remarks: This new genus includes only the species, M. laddi (Schultz). Synchiropus postulus Smith and Synchiropus (Synchiropus) minutulus Fricke are the synonyms of $M$. laddi. The characters to separate these three species, which are pointed out by Fricke (1981 c), seems to be infraspecific variations.

It is very small when mature. Male specimens about $20 \mathrm{~mm}$ in standard length had conspicuous secondary sexual characters. Therefore, this new genus has been named "Minysynchiropus".

This new genus is very like Paradiplogrammus and Diplogrammus in the shape of its preopercular spine.

\section{Genus Paradiplogrammus n. g.}

(Figs. 10, 24D, 29J)

Paradiplogrammus (type-species by original designation: Callionymus enteactis Bleeker).

Description: D. IV , 8-9; A. 7-8; $\mathrm{P}_{1}$. i+15-20, ii $+14-15 ; \mathrm{P}_{2}$. I, 5; C. i + $7+$ ii. 

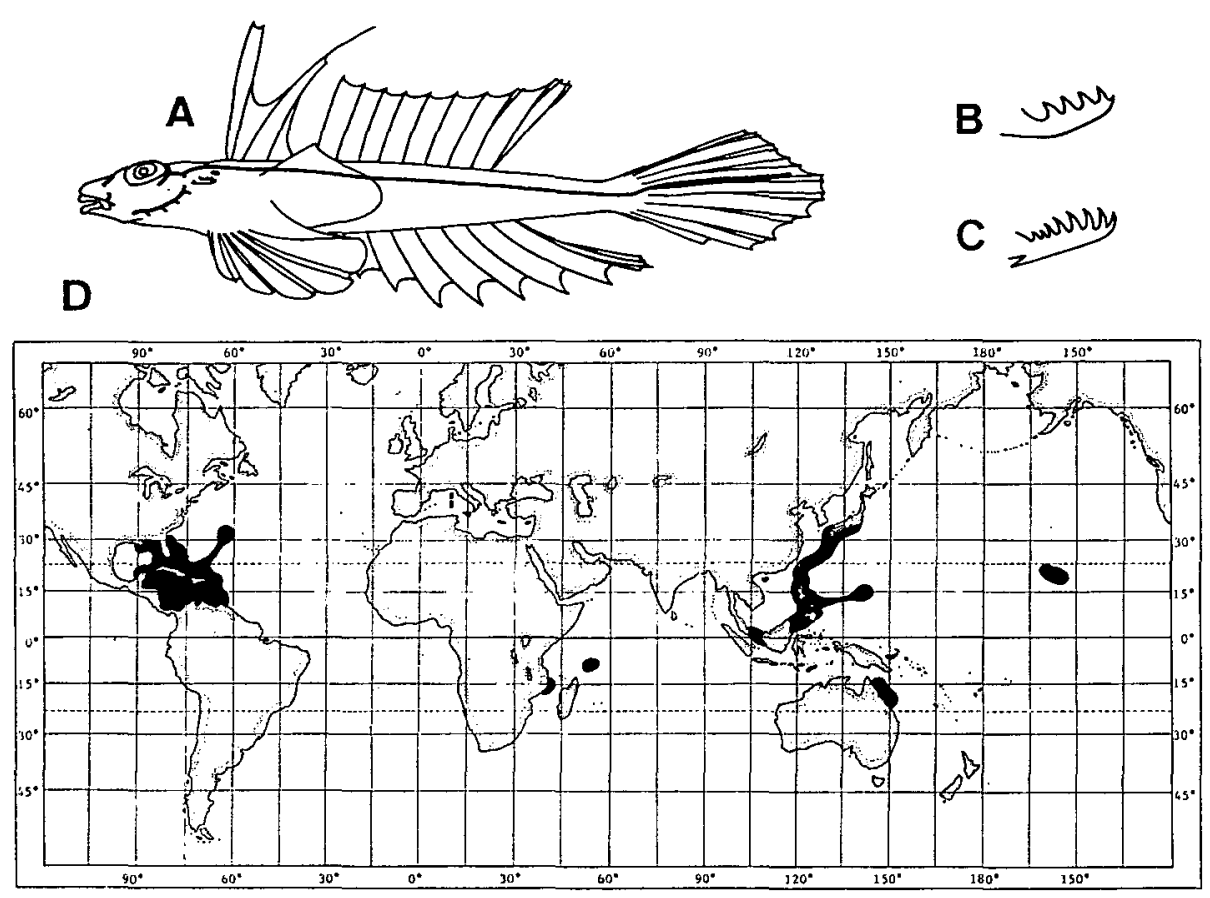

Fig. 10. Paradiplogrammus. A, lateral view of a $P$. calliste, male. Solid lines show the lateral line canals; B, preoprcular spine of $P$. sp.; C, preopercular spine of $P$. corallinus; $D$, geographic distribution of the genus.

Body moderately depressed. Gill-opening midway between posterior edge of eye and upper origin of pectoral fin. Tip of snout almost at tip of upper jaw. Preopercular spine with antrorse process at base (in some species none), many upward ones on inner side; posterior end strongly curved upward. Infraorbital canal not extending below eye; postocular commissure not connected with preoperculo-mandibular canal. Lateral line reaching near tip of a median caudal ray; the line of opposite side not connected by a transverse branch on dorsal surface of caudal peduncle.

First dorsal fin beginning just behind gill-opening; tips of most dorsal rays simple.

Pectoral fin double truncate. Tip of each anal ray, except last branched one, simple. Caudal fin rounded.

Color in preserved specimens. Body marbled dark brown above, white below.

SeCONDARY SEXUAL DIMORPHISM: First dorsal fin of the male is markedly larger and more colorful than that of the female.

Habitat: Sandy bottoms in weedy beds, pebbles, rocks and corals in shallow waters around islands.

Geographic Distribution: middle part of the western Atlantic; the western Indian Ocean; the western Pacific; the Hawaiian Isls.

Remarks: This new genus is closely related to Diplogrammus in its general physiognomy, especially that of the preopercular spine, but differs in having no dermal fold on the lateral ventral side of the body. 


\section{Genus Diplogrammus Gill, 1865}

(Figs. 11, 24E, 26C, 27, 29J)

Diplogrammus Gill, 1865, Lyc. Nat. Hist. New York, p. 143 (type-species by original designation: Callionymus goramensis Bleeker).

Calymmichthys Jordan and Thompson, 1914, Mem. Carnegie Mus., 6 (4), p. 296 (type-species by original designation: Calymmichthys xenicus Jordan and Thompson).

Dicallionymus Fowler, 1941, Proc. U.S. Nat. Mus., 90 (3106), p. 29 (type-species by original designation: Callionymus goramensis Bleeker).

Dermosteira Schltz, 1943, U.S. Nat. Mus. Bull. 180, p. 267 (type-species by original designation: Dermosteira dorotheae Schultz).

Climacogrammus Smith, 1963, Rhodes Univ. Ichthyol. Bulı., 28, p. 550 (type-species by original designation: Diplogrammus (Climacogrammus) inflatus Smith).

Diplogrammoiaes Smith, 1963, Rhodes Univ. Ichthyol. Bull., 28, p. 551 (type-speries by original designation: Diplogrammus (Diplogramnioides) gruveli Smith).

Chalinops Smith, 1963, Rhodes Univ. Ichthyol. Bull., 28, p. 552 (type-species by original designation: Callionymus floridae Fowler).

Description: D. IV, 6-8; A. 4-7; $\mathrm{P}_{1} . \mathrm{i}+16-18$, ii $+15-17 ; \mathrm{P}_{2} . \mathrm{I}, 5 ; \mathrm{G} . \mathrm{i}+$ $7+$ ii.

Body depressed. Eye moderately large. Gill-opening midway between posterior edge of eye and upper origin of pectoral fin; opercular flap as enlarged posterior part of subopercle below gill-opening in some species. Tip of snout almost at
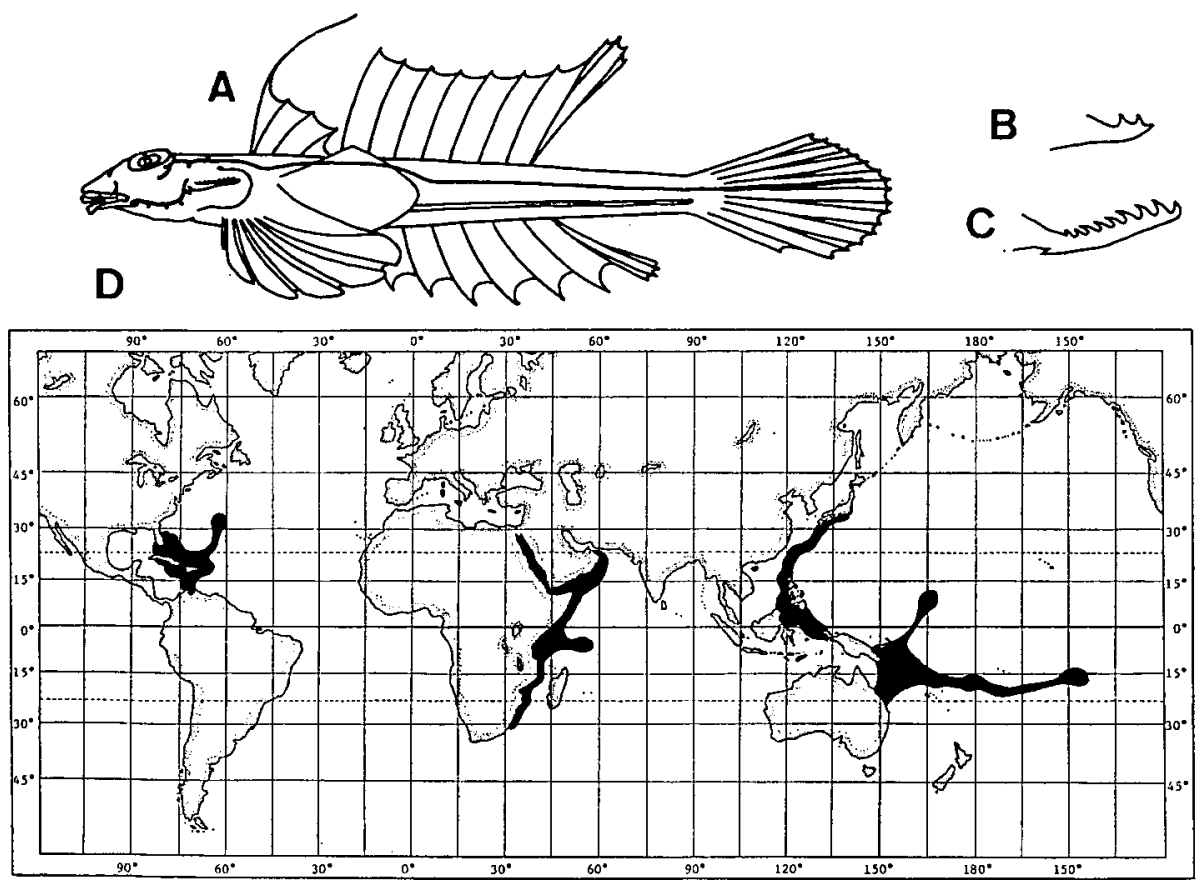

Fig. 11. Diplogrammus. A, lateral view of a D. xenicus, male. Solid lincs show the lateral line canals; B, preopercular spine of D. pauciradiatus; C, preopercular spine of D. xenicus; $\mathrm{D}$, geographic distribution of the genus. 
tip of upper jaw. Preopercular spine with antrorse process at base, many upward ones on inner side; posterior end strongly curved upward in some species. In others, preopercular spine with no antrorse process at base and two upward ones on inner side; posterior end slightly curved upward. Infraorbital canal not extending below eye. Postocular commissure not connected to preoperculo-mandibular canal. Lateral line of opposite side not interconnected by transverse branch on dorsal surface of caudal peduncle. Longitudinal dermal fold on lateral ventral side of body.

First dorsal fin begins before upper origin of pectoral fin. Tip of each dorsal and anal ray simple or bifurcate. Pectoral fin rounded or lanceolate.

Color in preserved specimens. Body marbled dark brown above, white below.

SECONDARY SEXUAL DIMORPHISM: In some species, the first dorsal fin of the male is markedly larger than that of the female.

Habitat: Sandy bottoms near weedy beds, pebbles and corals in shallow waters around islands.

GeOGRAPHic Distribution: middle part of the western Atlantic; the western Indian Ocean (the Red Sea, southeastern Africa); the western and southern Pacific.

REmarks: Many genera and subgenera have been established for the species of this genus because of the number of diagnostic characters. But the species have a common longitudinal dermal fold on the lateral ventral side of the body. No other callionymid species have this character; therefore, all these divisions should be included in the genus Diplogrammus.

\section{Genus Synchiropus Gill, 1860}

(Figs. 12, 25A, 29A)

Synchiropus Gill, 1860, Proc. Acad. Nat. Sci. Philad., 1859, p. 129 (type-species by original designation: Callionymus lateralis Richardson).

Description: D. IV, 8; A. 7; $\mathrm{P}_{1}$. i $+18 ; \mathrm{P}_{2}$. I, 5; C. i+7+ii.

Body cylindrical. Eye moderately large. Gill-opening on upper lateral side of body and after middle between posterior edge of eye and upper origin of pectoral fin. Snout short; its tip almost at tip of upper jaw. Preopercular spine elongate and straight with no antrorse process at base, two upward processes on inner side. Supraorbital canal not extending to tip of snout. Infraorbital canal simple, and not extending below eye. Postocular commissure not connected to preoperculomandibular canal. Lateral line reaching tip of median caudal ray; line of opposite side interconnected by transverse branch across dorsal surface of caudal peduncle; several long transverse branches on each side of dorsal surface of body; cross-shaped, separated branch before transverse commissure on caudal peduncle.

First dorsal fin beginning behind gill-opening. Tip of each dorsal ray bifurcate. Tip of each anal ray, except last branched one, simple. Upper half of pectoral fin slightly emarginated, lower half rounded. Caudal fin rounded. 

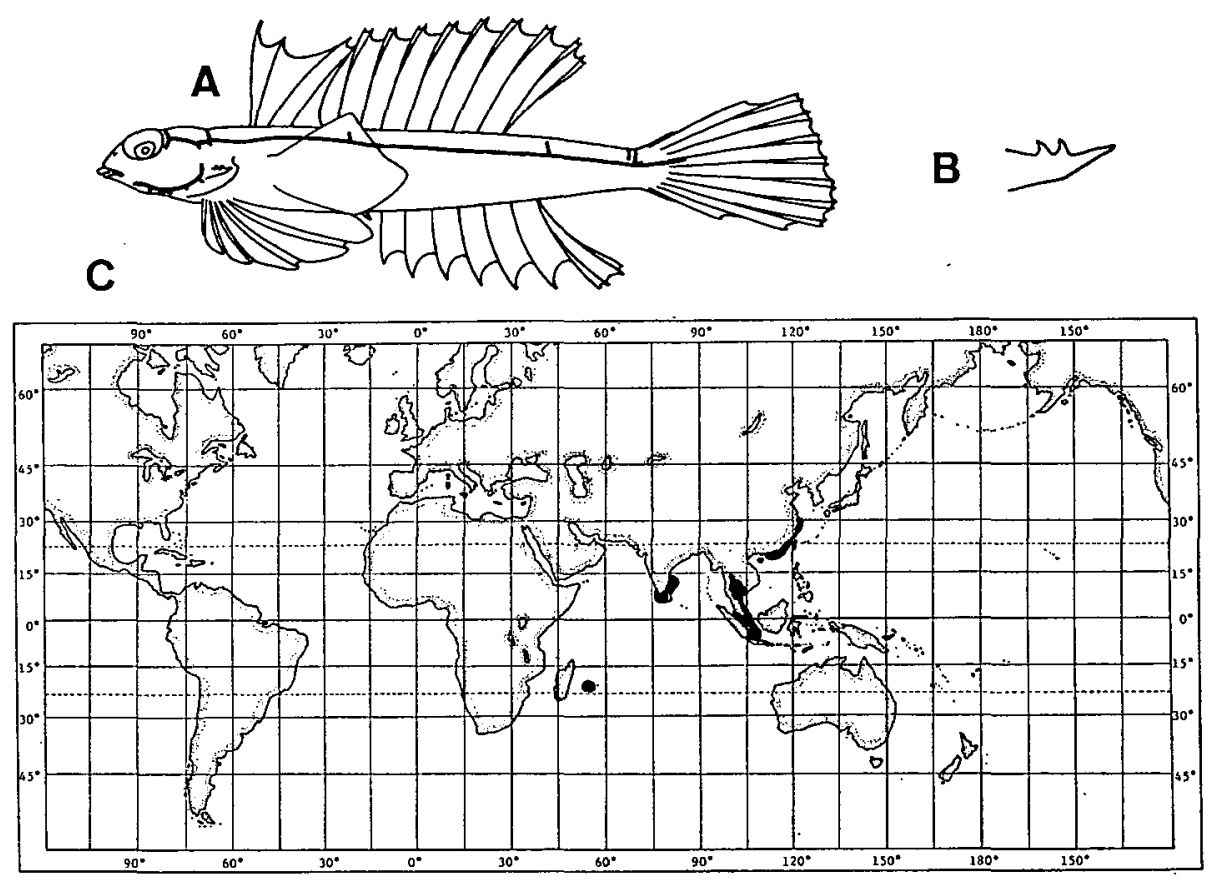

Fig. 12. Synchiropus. A, lateral view of a S. ornatus, male. Solid lines show the lateral line canals; B, preopercular spine of S. ornatus; C, geographic distribution of the genus.

Color in preserved specimens. Body marbled dark sepia-brown above, white below.

Secondary SEXUAL Dimorphism: It could not be studied.

Habitat: Muddy bottom on the continental shelf.

Geographic distribution: Tropical waters in the Indo-West Pacific.

Remarks: Gill (1860) established Synchiropus on the basis of five species. Subsequently, Regan (1908), Jordan and Thompson (1914), Norman (1939), Fowler (1941), Schultz and Woods (1948), de Beaufort (1951), Matsubara (1955), Schultz (1960), Ochiai (1963) and Smith (1963) included species with no antrorse process at the base of the preopercular spine in the genus Synchiropus. Recently, summing up the characters experienced by the earlier workers, Fricke (1981c) regarded Synchiropus as the genus characterized by the following: 1, gill openings sublateral or lateral in position; 2 , base of preopercular spine usually without an antrorse process; 3 , rays of second dorsal fin usually all branched, the last divided at its base; 4 , membrane behind the last spine of the first dorsal fin small or absent; 5, Snout very short, usually shorter than eye; 6-10, characters in the neurocranium.

My study, however, shows that, Synchiropus should include only species like $S$. lateralis, first described in Synchiropus by Gill (1860). Many of the species included into Synchiropus by the authors above, especially Fricke, are divided into seven genera (Foetorepus, Eocallionymus, Minysynchiropus, Neosynchiropus, Pterosynchiropus, Synchiropus and Orbonymus) in the present stydy. The characters summed up by Fricke are too 
variable to be treated as the generic characters and the seven genera have their own osteological characters (Nakabo, unpublished).

\section{Genus Orbonymus Whitley, 1947}

(Figs. 13, 25B, 29J)

Orbonymus Whitley, 1947, Aust. Zool., 11, p. 150 (type-species by original designation: Callionymus (Calliurichthys) rameus $\mathrm{McCulloch).}$

Description: D. IV, 8; A. 7: $\mathrm{P}_{1}$. i $+17-18 ; \mathrm{P}_{2}$. I, 5; G. $\mathrm{i}+7+\mathrm{ii}$.

Body slightly depressed. Gill-opening midway between posterior edge of eye and upper origin of pectoral fin. Snout short; its tip almost at tip of upper jaw. Preopercular spine straight and elongate with an antrorse process at base, many short upward ones on inner side. Supraorbital canal not extending to tip of snout. Infraorbital canal simple, not extending below eye. Postocular commissure not connected to preoperculo-mandibular canal. Lateral line reaching tip of median caudal ray; line of opposite side not interconnected by transverse branch on dorsal surface of caudal peduncle.

First dorsal fin beginning at gill-opening. Tip of each dorsal ray bifurcate. Upper half of pectoral fin emarginated, lower half rounded. Tip of each anal ray,
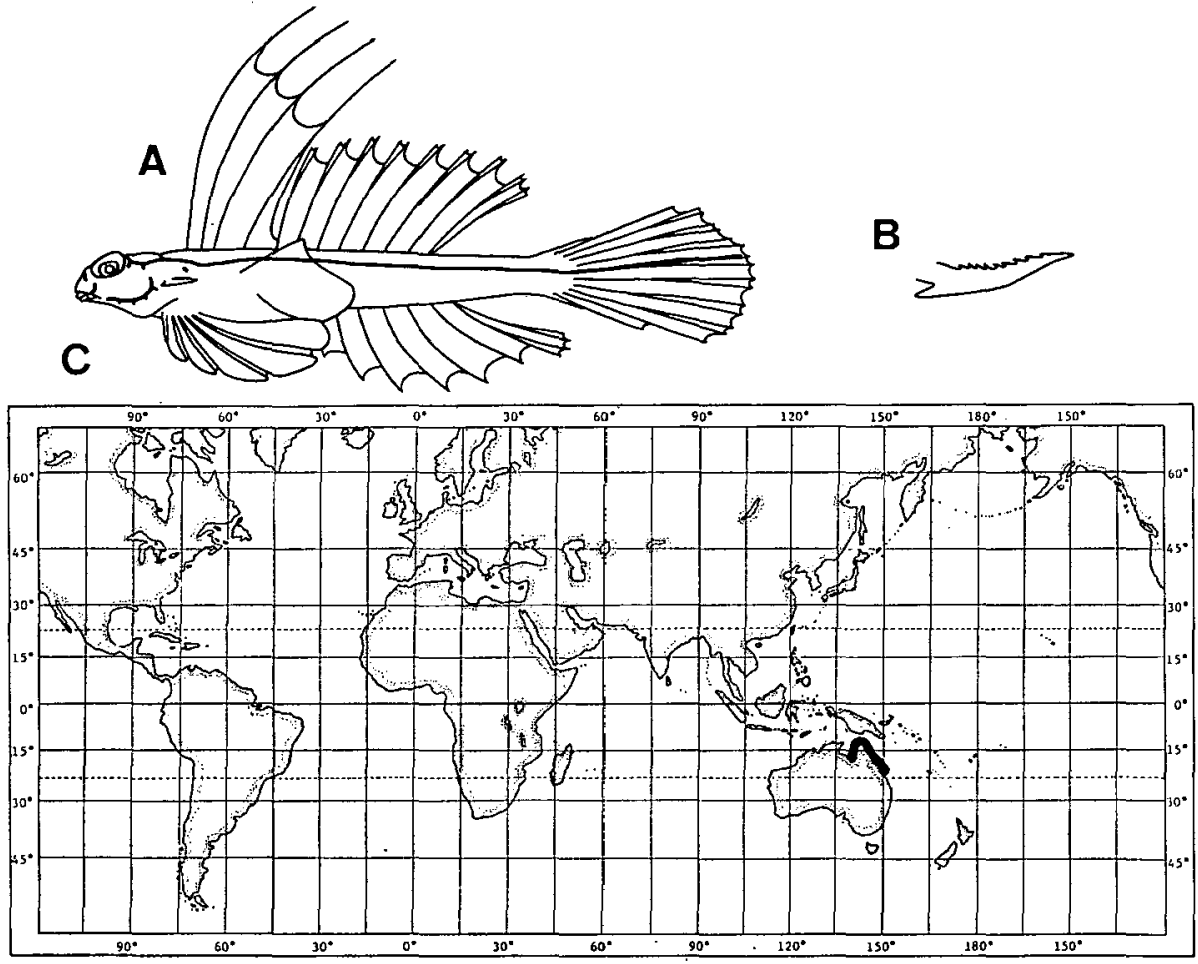

Fig. 13. Orbonymus. A, lateral view of a $O$. rameus, female. Solid lines show the lateral line canals; B, preopercular spine of $O$. raneus; $\quad$, geographic distribution of the genus. 
except last branched one, simple. Caudal fin rounded.

Color in preserved specimens. Body marbled dark sepia-brown above, white below.

SeCONDARY SEXUAL DIMORPHISM: First dorsal fins of males and females are markedly large; slightly larger in the male than in the female in $O$. rameus.

Habitat: Sandy rubble bottoms.

Geographic Distribution: coast of Queensland, Australia.

REMARks: Orbonymus is closely related to Dactylopus in its general physiognomy, but differs from it in the pelvic fin and preopercular spine.

\section{Genus Dactylopus Gill, 1860}

(Figs. 14, 25C, 29J)

Dactylopus Gill, 1860, Proc. Acad. Nat. Sci. Philad., 1859, p. 130 (type-species by original designation: Callionymus dactylopus Valenciennes).

Vulsus Gunther, 1861, Cat. Brit. Mus., III, p. 151 (type-species by original designation: Callionymus dactylopus Valenciennes).

Description: D. IV, $8 ;$ A. $7 ; \mathrm{P}_{1} . \mathrm{ii}+17 ; \mathrm{P}_{2} .1,1-4 ; \mathrm{C} . \mathrm{i}+7+\mathrm{ii}$.

\section{C}
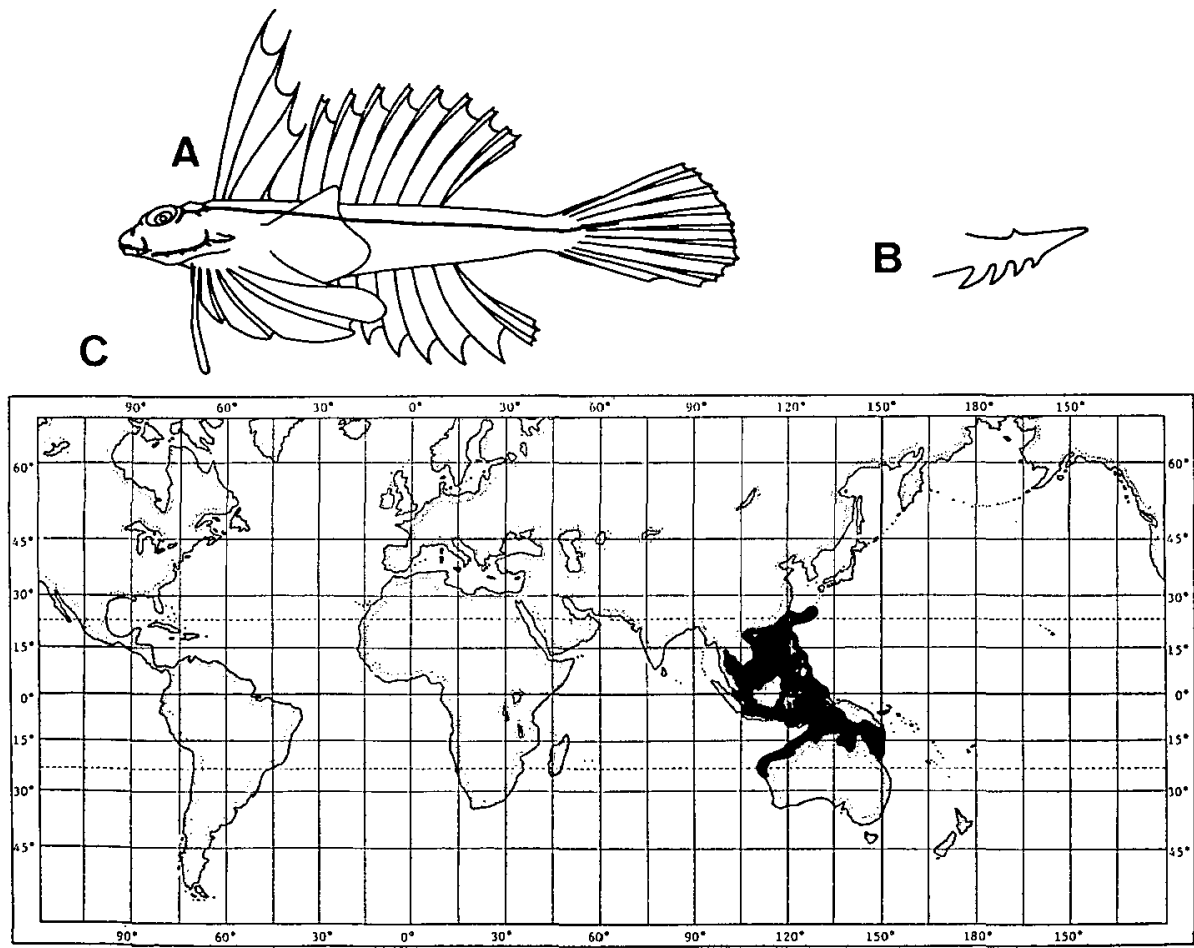

Fig. 14. Dactylopus. A, lateral view of a $D$. dactylopus, female. Solid lines show the lateral line canals; $B$, preopercular spine of $D$. dactylopus; $C$, geographic distribution of the genus. 
Body slightly depressed. Gill-opening behind middle between posterior edge of eye and upper origin of pectoral fin. Snout short; its tip almost at tip of upper jaw. Occipital region rugose. Preopercular spine straight with several antrorse processes on outer side, several small upward ones on inner side. Supraorbital canal not extending to tip of snout. Infraorbital canal simple, not extending below eye. Postocular commissure not connected to preoperculo-mandibular canal. Lateral line reaching tip of median caudal ray; line of opposite side not interconnected by transverse branch on dorsal surface of caudal peduncle.

First dorsal fin beginning well before gill-opening. Tip of each dorsal ray bifurcate. Upper half of pectoral fin slightly emarginated, lower half rounded. Pelvic spine and first pelvic ray fused form elongate rod separated from other pelvic rays. Tip of each anal ray, except last branched one, simple.

Color in preserved specimens. Body marbled dark sepia-brown above, white below.

Secondary sexual dimorphism: Each tip of dorsal spine are elongate and filamentous in the male, but not in the female.

Habitat: Sandy rubble bottoms in shallow waters around islands.

Geographic Distribution: the western Pacific and north coast of Australia.

Genus Calliurichthys Jordan and Fowler, 1903

(Figs. 15, 22A, 26E, 29D. J. K)

Calliurichthys Jordan and Fowier, 1903, Proc. U.S. Nat. Mus., 25 (1305), p. 941 (type-species by original designation: Callionymus japonicus Houttuyn).

Description: D. IV, 9; A. 8; $\mathrm{P}_{1}$. ii $+16-19 ; \mathrm{P}_{2}$. I, 5; C. i+7+ii.

Body elongate and strongly depressed. Gill-opening midway between posterior edge of eye and upper origin of pectoral fin. Tip of snout a little behind tip of upper jaw (in males of some species, almost at tip of upper jaw). Occipital region rugose. Preopercular spine straight and elongate with an antrorse process at base, many short upward processes on inner side. Supraorbital canal not extending near tip of snout. Infraorbital canal branched, not extending below eye (in C. japonicus, extends below eye). Postocular commissure connected to preoperculo-mandibular canal in some species, but in others the latter canal cut above preopercular spine. Short antrorse branch of canal near distal end of preoperculo-mandibular canal. Lateral line reaching tip of median caudal ray; line of opposite side interconnected by transverse branch across dorsal surface of caudal peduncle (in $C$. neptunius interconnected both on dorsal and ventral surfaces). In most species, several separated short transverse branches on each side of dorsal surface of body and T-shaped separated branch before transverse commissure on caudal peduncle.

First dorsal fin beginning behind gill-opening. Tip of each dorsal and anal ray, except last branched one, simple. Upper half of pectoral fin slightly emarginated, lower half rounded. 

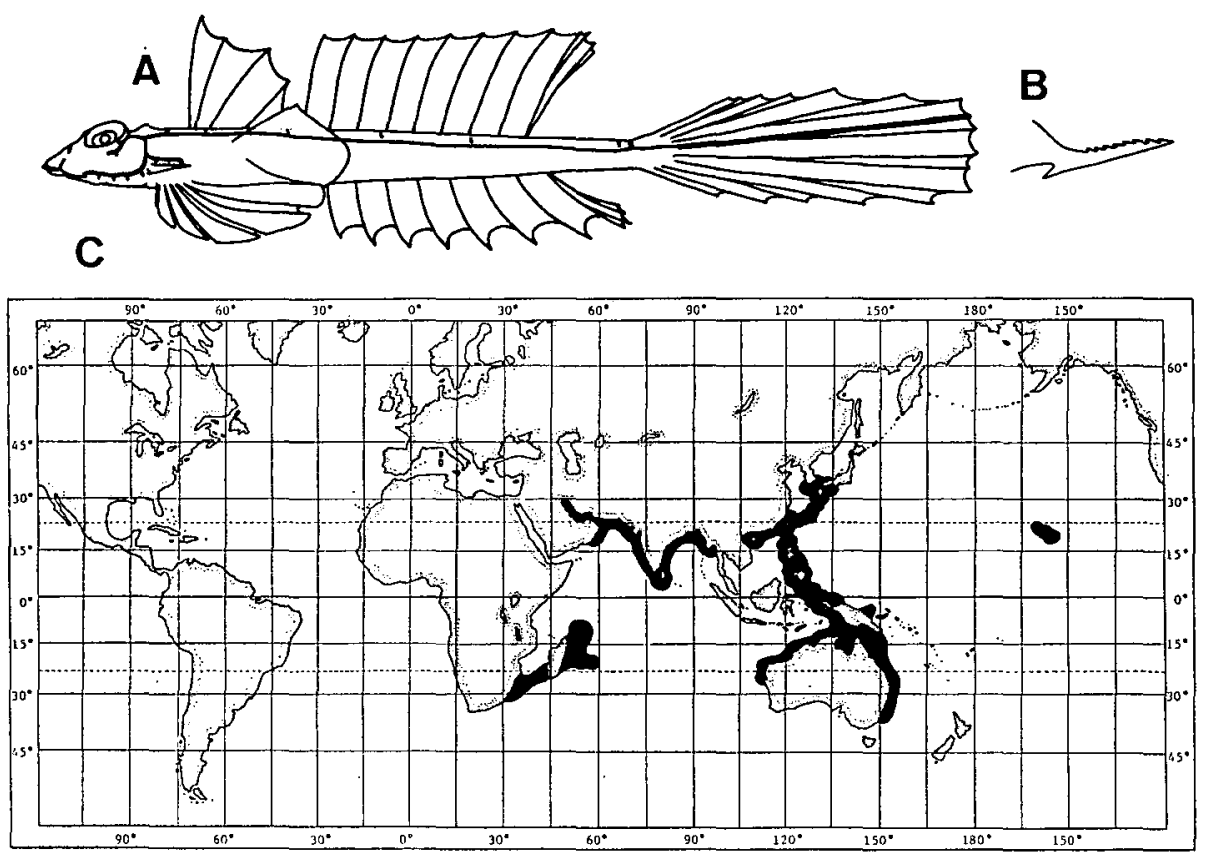

Fig. 15. Calliurichthys. A, lateral view of a C. japonicus, female. Solid lines show the lateral line canals; B, preopercular spine of C. japonicus; $\mathrm{C}$, geographic distribution of the genus.

Color in preserved specimens. Body marbled dark sepia-brown above, white below.

SECONDARY SEXUAL DIMORPHISM: In most species, the male has a much longer caudal fin than the female, almost equal to its body length.

Habitat: Sandy-muddy bottoms on the continental shelf, its edges and on banks.

Geographic Distribution: coastal waters of the Indian Ocean (including the Red Sea and Persian Gulf); the western Pacific (including the East China and South Ghina Seas); west, north and east coasts of Australia; the Hawaiian Isls.

Remarks: Jordan and Fowler (1903) established Calliurichthys on the basis of three species from Japan, Callionymus japonicus Houttuyn, Callionymus variegatus Temminck and Schlegel, and Calliurichthys doryssus Jordan and Fowler because these three have a straight preopercular spine with several short upward processes on the inner side. McCulloch (1926) and Fricke (1980) regarded Calliurichthys as a subgenus of Callionymus. de Beaufort (1951) and Ochiai et al. (1955) considered this genus a synonym for Callionymus. Barnard (1927) regarded Calliurichthys a valid genus.

My study shows that Calliurichthys, as established by Jordan and Fowler, should be separated into three genera, Calliurichthys, Pseudocalliurichthys and Repomucenus. Their respective diagnostic characters represent distinct generic phenomena. Calliurichthys should be separated from Callionymus and limited only to species having the characters described above. 


\section{Genus Pseudocalliurichthys n. g.}

(Figs. 16, 25D, 26D, 29J) legel).

Pseudocalliurichthys (type-species by original designation: Callionymus variegatus Temminck and Sch-

Description: D. IV, 8; A. 7; $\mathrm{P}_{1} . \mathrm{i}+17-18$, ii $+14-17 ; \mathrm{P}_{2} . \mathrm{I}, 5 ; \mathrm{C} . \mathrm{i}+7+\mathrm{ii}$.

Body elongate and depressed. Gill-opening midway between posterior edge of eye and upper origin of pectoral fin. Snout very long. Upper jaw well protruding anterior. Occipital region rugose. Preopercular spine straight with antrorse process at base, many short upward processes on inner side. Supraorbital canal not extending to tip of snout. Infraorbital canal not extending below eye. Postocular commissure not connected to preoperculo-mandibular canal. Lateral line nearly reaching tip of median caudal ray; line of opposite side not interconnected by transverse branch on dorsal surface of caudal peduncle.

First dorsal fin beginning behind gill-opening. Tip of each dorsal and anal ray, except last branched one, simple. Upper half of pectoral fin slightly emarginated, lower half rounded.

Color in preserved specimens. Body marbled dark brown (like the surface of a sandy bottom) above, white below.

SECONDARY SEXUAL DIMORPHISM: In $P$. variegatus, the male has two filamentous
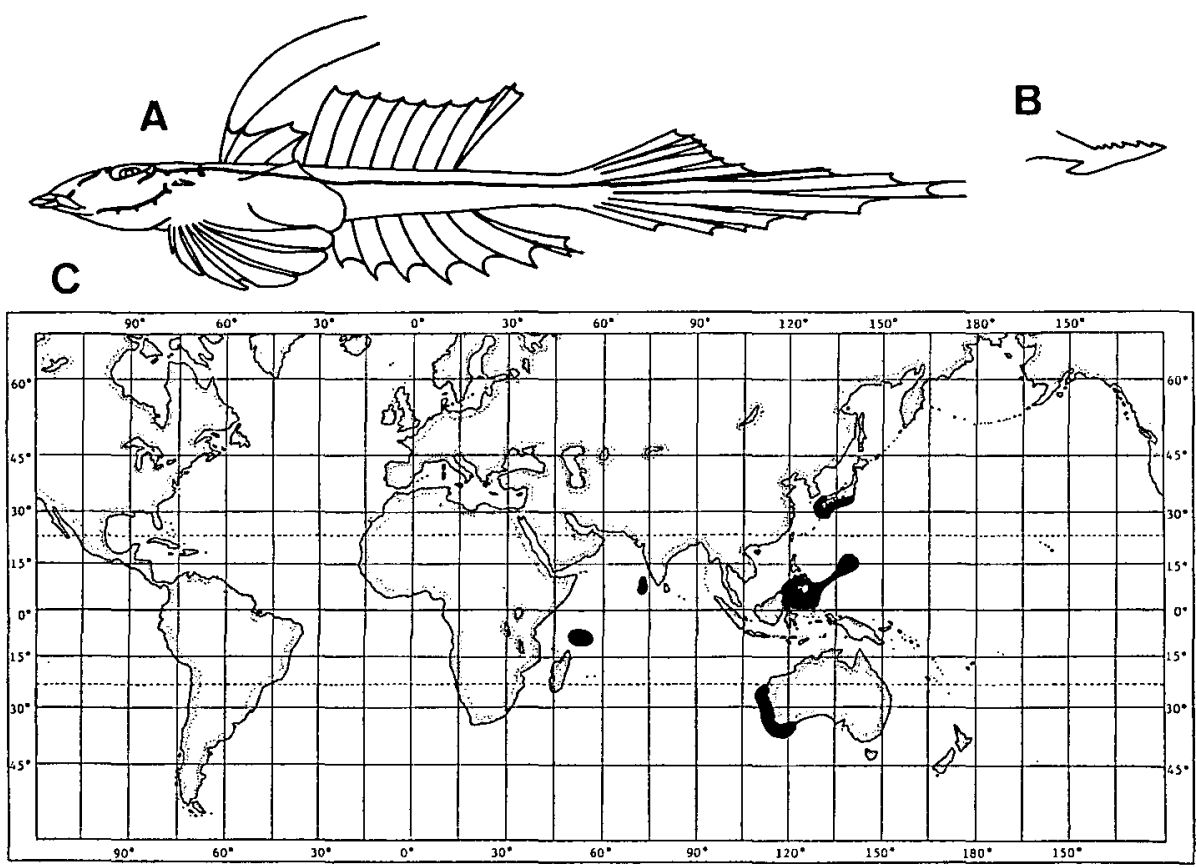

Fig. 16. Pseudocalliurichthys. A, lateral view of a $P$. variegatus, male. Solid lines show the lateral line canals; $\mathrm{B}$, preopercular spine of $P$. variegatus; $\mathrm{C}$, geographic distribution of the genus. 
dorsal spines and markedly elongate caudal fin.

Habitat: Sandy bottoms in coral reefs and weedy beds around islands.

Geographic Distribution: the Indian Ocean; the western Pacific; coast of western Australia.

Remarks: Pseudocalliurichthys is closely related to Calliurichthys in its straight and serrated preopercular spine and a rugose occipital region. It differs in the number of dorsal and anal rays, and in having no short separated transverse branch of the lateral line. This genus also in closely related to Repomucenus because of the preopercular spine found during early stages of its growth and its body color.

\title{
Genus Repomucenus Whitley, 1931
}

(Figs. 17, 22B, 29H.I)

\begin{abstract}
Repomucenus Whitley, 1931a, Aust. Zool., 6 (4), p. 323 (type-species by original designation: Callionymus calcaratus Macleay).

Callimucenus Whitley, 1934, Suppl. Checklist Fishes New South Wales, ed. 3, No. 398, p. 418 (type-species by original designation: Callionymus macdonaldi).

Velesionymus Whitley, 1934, ibid, p. 418 (type-species by original designation: Callionymus limiceps).
\end{abstract}

Description: D. III-IV, 9 (mostly IV, 9); A. 8-9 (mostly 9); $\mathrm{P}_{1} . \mathbf{i}+16-21$; $\mathrm{P}_{2}$. I, 5; C. i+7+ii.

Body elongate and strongly depressed. Eye moderately large. Gill-opening midway between posterior edge of eye and upper origin of pectoral fin. Snout long. Upper jaw protruding anterior. Preopercular spine with an antrorse process at base, several upward processes on inner side; posterior end slightly curved upward (in some species, almost straight with several short upward processes). Supraorbital canal extending nearly to tip of snout. Infraorbital canal extending below eye with several downward or upward branches. Postocular commissure connected to preoperculo-mandibular canal; the latter above preopercular spine with an antrorse and a retrorse short branches, below them with a long retrorse branch.

First dorsal fin beginning behind gill-opening. Second dorsal fin emarginated. Tip of each dorsal and anal ray, except last branched ones, simple. Upper half of pectoral fin emarginated, lower half rounded.

Color in preserved specimens. Body marbled brown (like the surface of a sandy bottom), white below.

SEcondary SEXUAL Dimorphism: In some species, the first dorsal fin of the male is much larger and more colorful than that of the female; the dorsal rays of the male are elongate and filamentous.

Habitat: Sandy-muddy bottoms on the continental shelf.

Geographic Distribution: coastal waters of the Indian Ocean (including the Red Sea and Persian Gulf); the western Pacific (including the East China and South China Seas); all coasts of Australia; the eastern Mediterranean near the Suez Canal. 


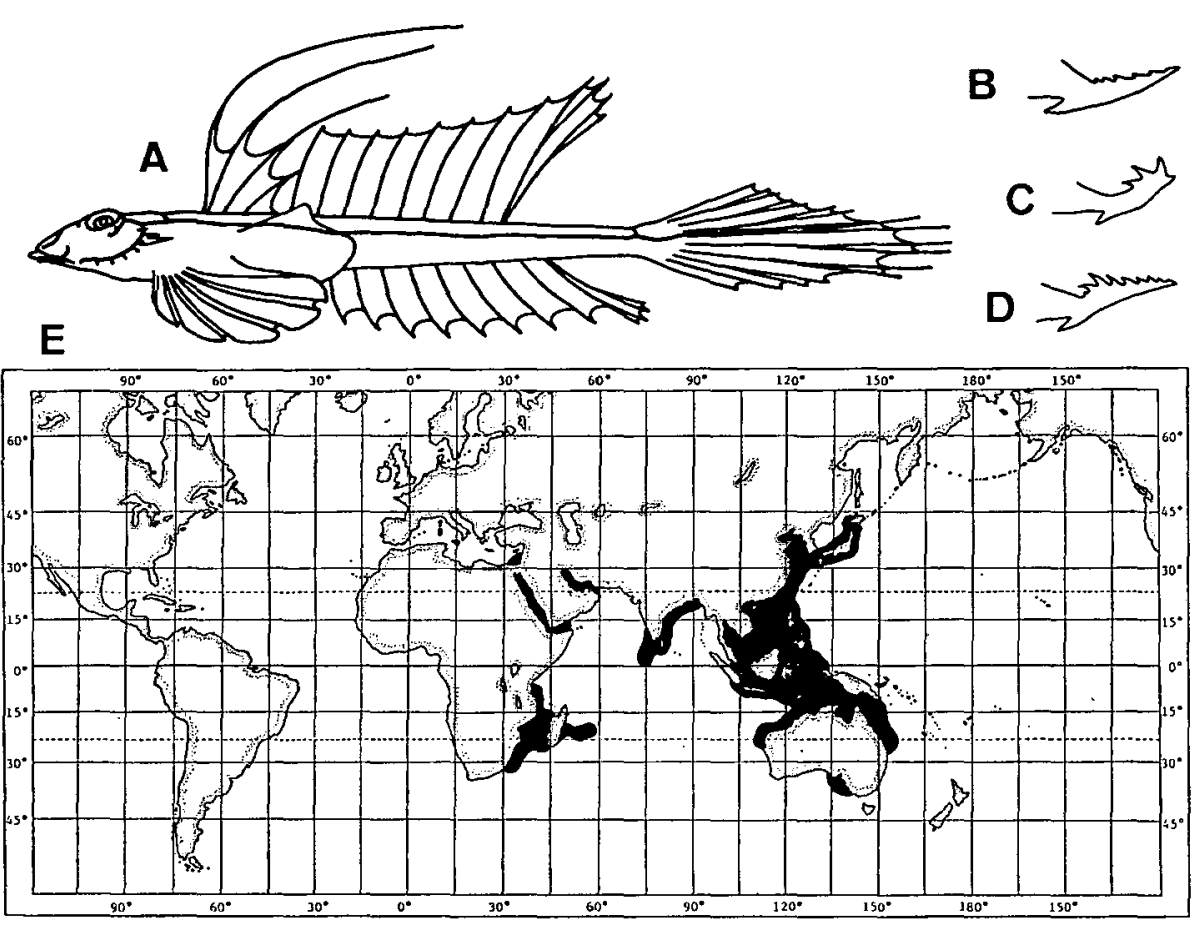

Fig. 17. Repomucenus. A, lateral view of a $R$. huguenini, male. Solid lines show the lateral line canals; B, C and D, preopercular spine of R. huguenini, R. vichardsonii and R. belcheri; $\mathrm{E}$, geographic distribution of the genus.

Remarks: Whitley (1931a) established Repomucenus on the basis of Callionymus calcaratus, but his description of this genus is not definitive. In 1934, he established Callimucenus and Velesionymus on the bases of Callionymus macdonaldi and C. limiceps. These three species have common diagnostic characters and should be included in the genus Repomucenus.

Almost all the members of the genus Repomucenus have been included in Callionymus; but Repomucenus differs from Callionymus in the preopercular spine, the pattern of the cephalic lateral line and the long transverse branch of the lateral line. Therefore, the two genera should be separated.

Repomucenus originally was not distributed in the Mediterranean. R. filamentosus found in the eastern Mediterranean, is from the Red Sea (Tortonese, 1964; BenTuvia, 1978).

This genus has the most species of this family.

\section{Genus Spinicapitichthys Fricke, 1980}

(Figs. 18, 28, 29J·K)

Spinicapitichthys Fricke, 1980, East. Ann. Mus. Civico St. Nat. Genova, 83, p. 60 (type-species by original designation: Callionymus spiniceps Regan). 

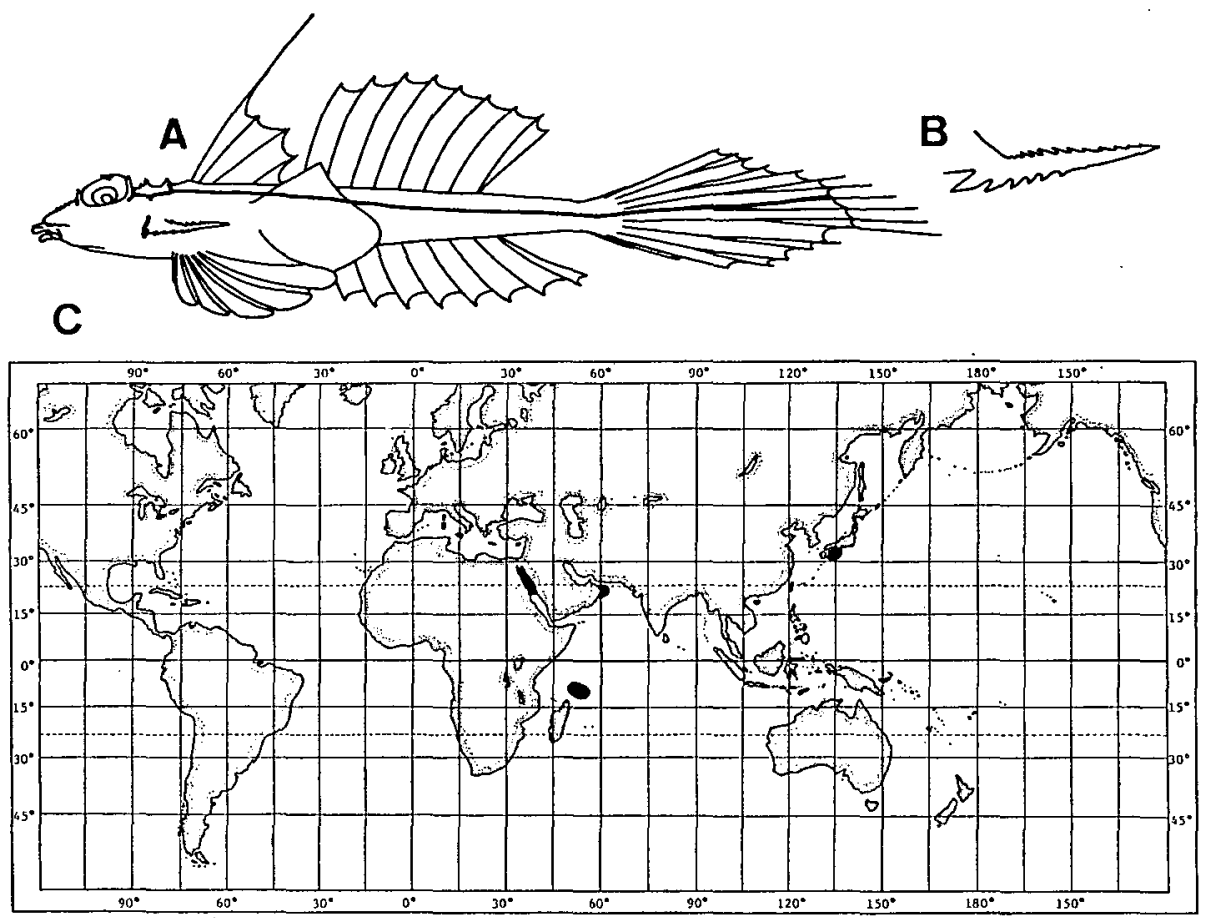

Fig. 18. Spinicapitichthys. A, lateral view of a S. spiniceps, female. Solid lines show the lateral line canals; B, preopercular spine of S. spiniceps; C, gcographic distribution of the genus.

Description: D. IV, 8; A. 8; $\mathrm{P}_{1} . \mathrm{i}+18-20 ; \mathrm{P}_{2} . \mathrm{I}, 5 ; \mathrm{G} . \mathrm{i}+7+\mathrm{ii}$.

Body elongate and depressed. Eye large. Gill-opening midway between posterior edge of eye and upper origin of pectoral fin. Upper jaw protruding anterior. Occipital region with spines. Preopercular spine straight, many processes on outer and inner sides. Supraorbital canal extending slightly after nasal pore. Infraorbital canal simple, not extending below eye. Preoperculo-mandibular canal very short, only near preopercular spine. Lateral line reaching tip of median caudal ray; line of opposite side not interconnected on dorsal surface of caudal peduncle in most species (in $S$. oxycephalus interconnected both on dorsal and ventral surfaces).

First dorsal fin beginning at gill-opening. Tip of each ray of dorsal and anal fins simple. Upper half of pectoral fin slightly emarginated, lower half rounded.

Color in preserved specimens. Body marbled brown above, white below.

SEcondary SEXUAL DIMORPhism: The caudal fin of the male is longer than that of the female.

Haвitat: Sandy-muddy bottoms in deep waters near the edge of the continental shelf and on banks.

Geographic Distribution: Gulf of Suez; the Seychelles, Saya de Malha Bank; Muscat; Japan.

REMARKs: Fricke (1980) established Spinicapitichthys a subgenus of Callionymus. 
But Spinicapitichthys should be regarded as a genus separate from Callionymus. Many of its conspicuous diagnostic characters are generic ones.

\section{Genus Anaora Gray, 1835}

(Figs. 19, 25E, 29J)

Anaora Gray, 1835, Illustrations of Indian Zoology (type-species by original designation: Anaora tentaculata Gray).

Amcra Gray, 1835, Illustrations of Indian Zoology (may be a typographical error).

Description: D. IV, 8; A. 7; $\mathrm{P}_{1} .21-25$ (tips of most rays simple); $\mathrm{P}_{2}$. I, 5 ; C. ii $+6+$ ii.

Body cylindrical. Eye moderately large. Short thread-like cirrus on the dorsoposterior edge of eye. Gill-opening midway between posterior edge of eye and upper origin of pectoral fin. Upper jaw protractile, oblique ventrally. Teeth on both upper and lower jaws degenerative. Preopercular spine with an antrorse process at base, upward process on inner side; posterior end pointed. Occipital region with a pair of bony tubercles. Infraorbital canal not extending below eye. Postocular commissure not connected to preoperculo-mandibular canal. 'Lateral line reaching base of caudal fin; line of opposite side not interconnected by transverse branch on dorsal surface of caudal peduncle.

First dorsal fin short, beginning slightly before upper origin of pectoral fin. Second dorsal fin emarginated. Tip of each dorsal and anal ray, except last branched ray, simple. Caudal fin with 6 bifurcate rays.

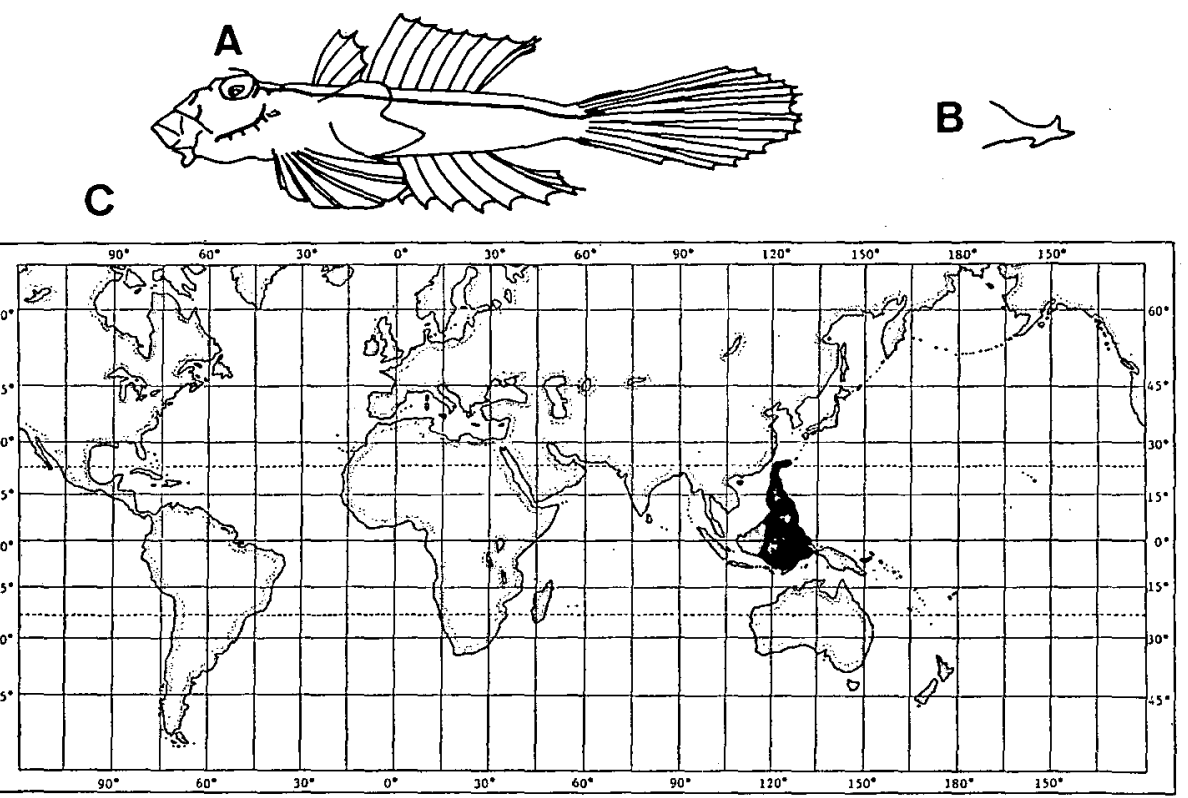

Fig. 19. Anaora. A lateral view of a A. tentaculata, male. Solid lines show the lateral line canals; B, preopercular spine of A. tentaculata; C, geographic distribution of the genus. 
Color in preserved specimens. Body marbled brown above, white below. In some specimens of $A$. tentaculata, body pinkish above, white below.

SECONDARY SEXUAL characters: The caudal fin of the male is larger than that of the female.

Habitat: Sandy bottoms in shallow waters around islands.

Geographic Distribution: Ryukyu Isls.; the Philippines; Borneo, Gelebes and western New Guinea.

\section{Genus Eleutherochir Bleeker, 1879}

(Figs. 20, 22C, 29H)

Eleutherochir Bleeker, 1879, Versl. Akad. Amsterdam, 14, p. 102 (type-species by original designation: Callionymus opercularioides Bleeker).

Draculo Snyder, 1911, Proc. U.S. Nat. Mus., 40 (1836), p. 545 (type-species by original designation: Draculo mirabilis Snyder).

Draculus Jordan, Tanaka and Snyder, 1913, J. Coll. Sci., Imp., Univ. Tokyo, 33 (1), p. 377 (may be a typographical error).

Brachycallionymus Herre and Myers, in Herre, 1936, Proc. Biol. Soc. Washington, 49, p.' 12 (typespecies by original designation: Brachycallionymus mirus Herre).

Pogonymus Gosline, 1959, Paci. Sci. 13 (1), p. 72 (type-species by original designation: Pogonymus pogognathus Gosline).

Charibarbitus Smith, 1963, Rhodes Univ. Ichthyol. Bull., 28, p. 562 (type-species by original designation: Charibarbitus celetus Smith).

Clathropus Smith, 1965, Ann. Mag. Nat. Hist. Ser. 13, vol. 8, p. 321 (type-species by original designation: Clathropus maugei Smith).

Desaription: D. absent or I-IV, 9-13; A. 9-13; $\mathrm{P}_{1}$. i+16-23; $\mathrm{P}_{2}$. I; 5; C. $\mathrm{i}+7+\mathrm{ii}, \mathrm{ii}+6+\mathrm{ii}$.

Ethmoidal region strongly depressed. Mouth large laterally. Upper margin of lower lip with row of many papillae. Row of very small teeth on upper and lower jaws. Lower jaw somewhat protractile anteriorly. In some species, transverse isthmial fold connects branchiostegal membranes from each side and unfolds when lower jaw protrudes anteriorly. Preopercular spine with no antrorse process at base, 2-5 upward processes on inner side; posterior end strongly curved upward. Cephalic lateral line well developed; infraorbital canal extending to middle of cheek with some short branches. Postocular commissure connected to preoperculo-mandibular canal, the latter above preopercular spine with short and long retrorse branch. Lateral line reaching tip of median caudal ray; line of opposite side interconnected by transverse branch across dorsal surface of caudal peduncle.

First dorsal fin degenerative. Tips of posterior 1-5 dorsal rays bifurcate. Pectoral fin lanceolate. Almost no membrane between pelvic fin and pectoral fin base. Caudal fin rounded.

Color in preserved specimens. Body dark brown above, white below.

Secondary sexual dimorphism: Rare.

Habitat: Sandy bottoms in very shallow waters (beach). One species, Eleutherochir opercularis, enters brackish waters. 


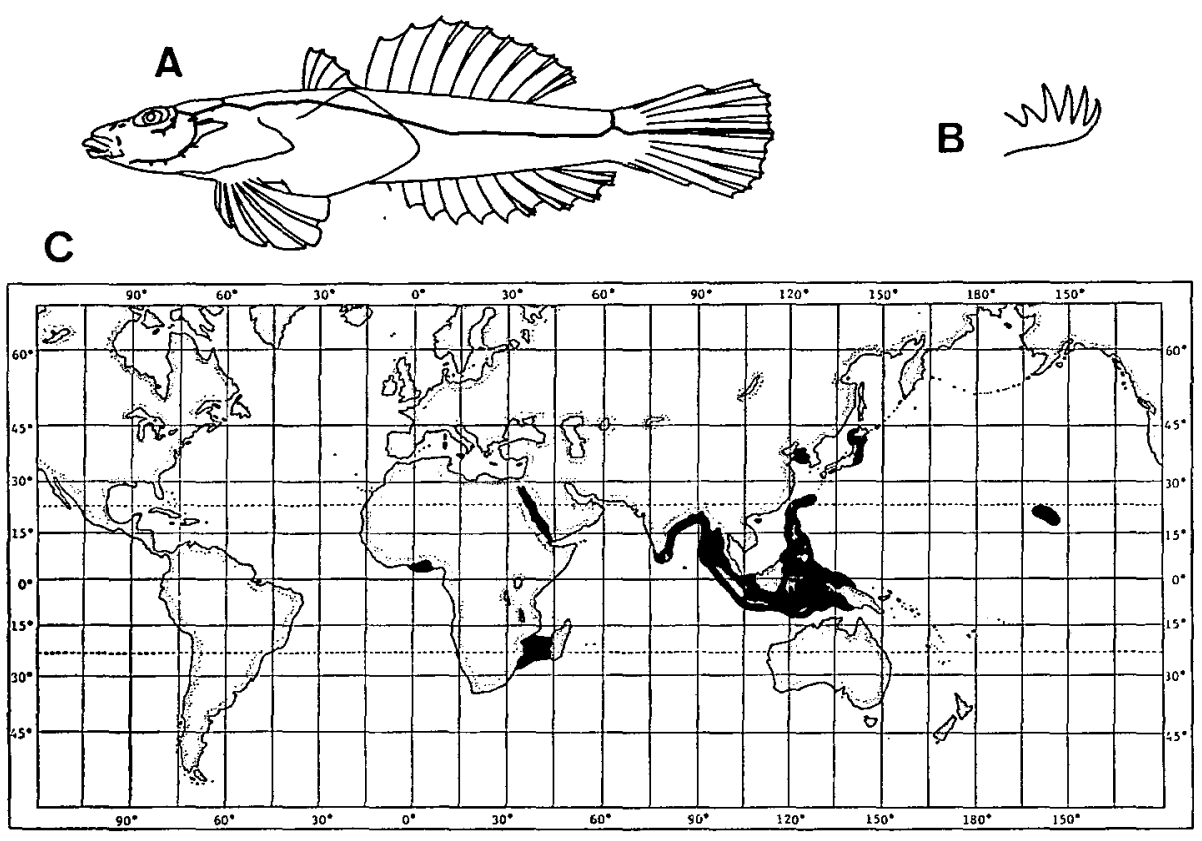

Fig. 20. Eleutherochir. A, lateral view of an $E$. opercularis, male. Solid lines show the lateral line canals; B, preopercular spine of E. mirabilis; $\mathrm{C}$, geographic distribution of the genus.

GEOGRAPHIC DISTRIBUTION: coast of Nigeria; Red Sea; southeast coast of Africa; east coast of India; Indonesia; Borneo; Celebes; New Guinea; the Philippines; Japan; Po Hai; the Hawaiian Isls.

Remarks: Bleeker established Eleutherochir on the basis of a protruding lower jaw, an opercular flap, and lack of a membrane between the pelvic fin and the pectoral fin base. Others have established different genera for the species in this genus because of the various diagnostic characters. But, the various genera have the diagnostic characters described above, in common, and should be included in the genus Eleutherochir.

\section{Discussions of External Characters}

1) Cephalic lateral line

The cephalic lateral line patterns, especially in the infraorbital and preoperculomandibular canals, can be separated into seven types. A simple infraorbital canal and preoperculo-mandibular canal with five short branches, Type A, is seen in Callionymus, Foetorepus, Eocallionymus and Minysynchiropus (Fig. 22). A branched infraorbital canal and a preoperculo-mandibular canal above the preopercular spine with one or two short branches and a long branch, Type B, is seen in Calliurichthys, Repomucenus and Eleutherochir (Fig. 22). A branched infraorbital canal and preoperculo-mandibular canal separated into many parts, the part above the preopercular spine with 
a branch, Type C, is seen in Callionymus (Fig. 23). A simple infraorbital canal and preoperculo-mandibular canal divided into two parts above the preopercular spine, Type D, is seen in Callionymus, Neosynchiropus, Pterosynchiropus, Paradiplogrammus, Diplogrammus, Synchiropus, Orbonymus, Dactylopus, Pseudocalliurichthys and Anaora (Figs. 24, 25). A branched infraorbital canal and preoprculo-mandibular canal divided into two parts above the preopercular spine, Type $\mathrm{E}$, is seen in Bathycallionymus,

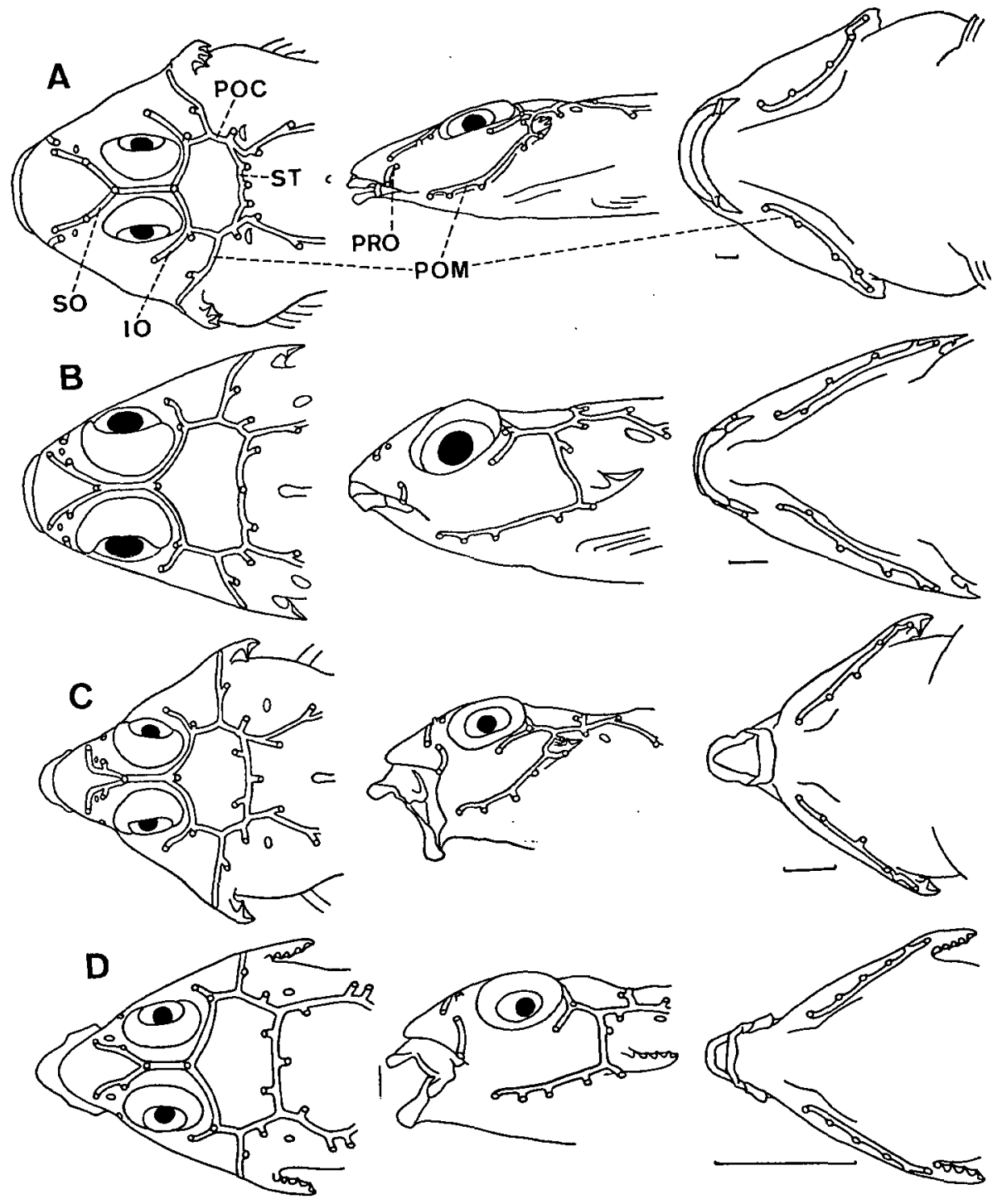

Fig. 21. The cephalic lateral line in four callionymid species. A, Callionymus lyra; B, Foetorepus altivelis; C, Eocallionymus papilio; D. Minysynchiropus laddi. IO, infraorbital canal; POC, postocular commissure; POM, preoperculo-mandibular canal; PRO, preorbital canal; SO, supraorbital canal; ST, supratemporal canal. Left, dorsal view; middle, lateral view; right, ventral view. Scales indicate $5 \mathrm{~mm}$. 


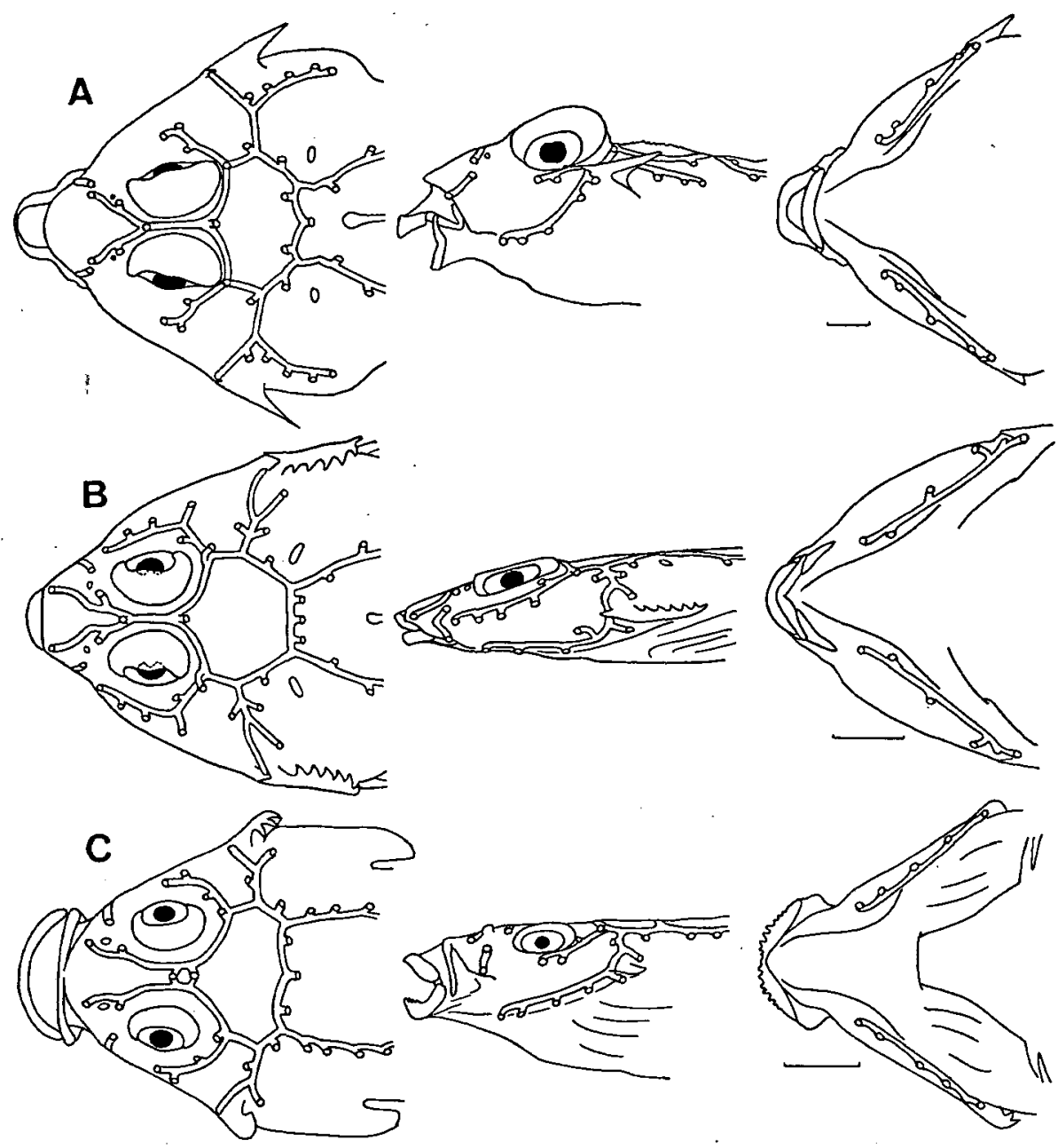

Fig. 22. The cephalic lateral line in three callionymid species. A, Calliurichthys japonicus; B, Repomucenus planus; C, Eleutherochir mirabilis. Left, dorsal view; middle, lateral view; right, ventral view. Scales indicate $5 \mathrm{~mm}$.
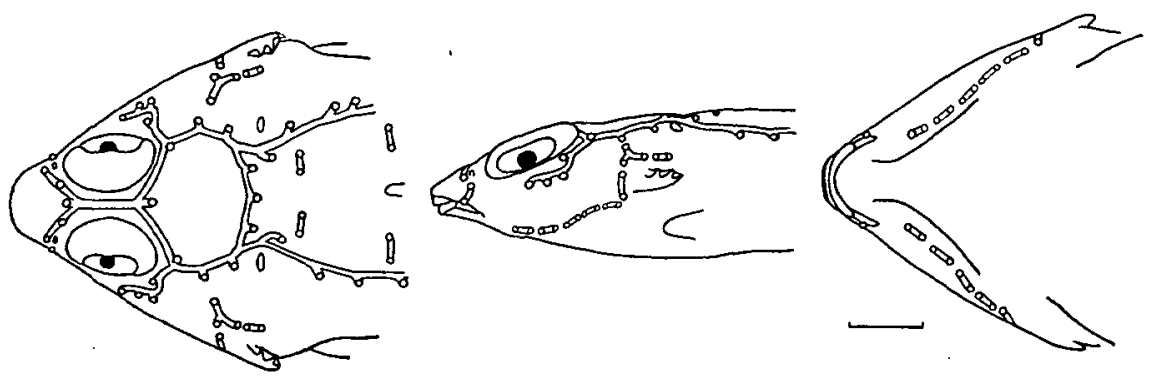

Fig. 23. The cephalic lateral line in Callionynus risso. Left, dorsal view; middle, lateral view; right, ventral view. Scale indicates $5 \mathrm{~mm}$. 


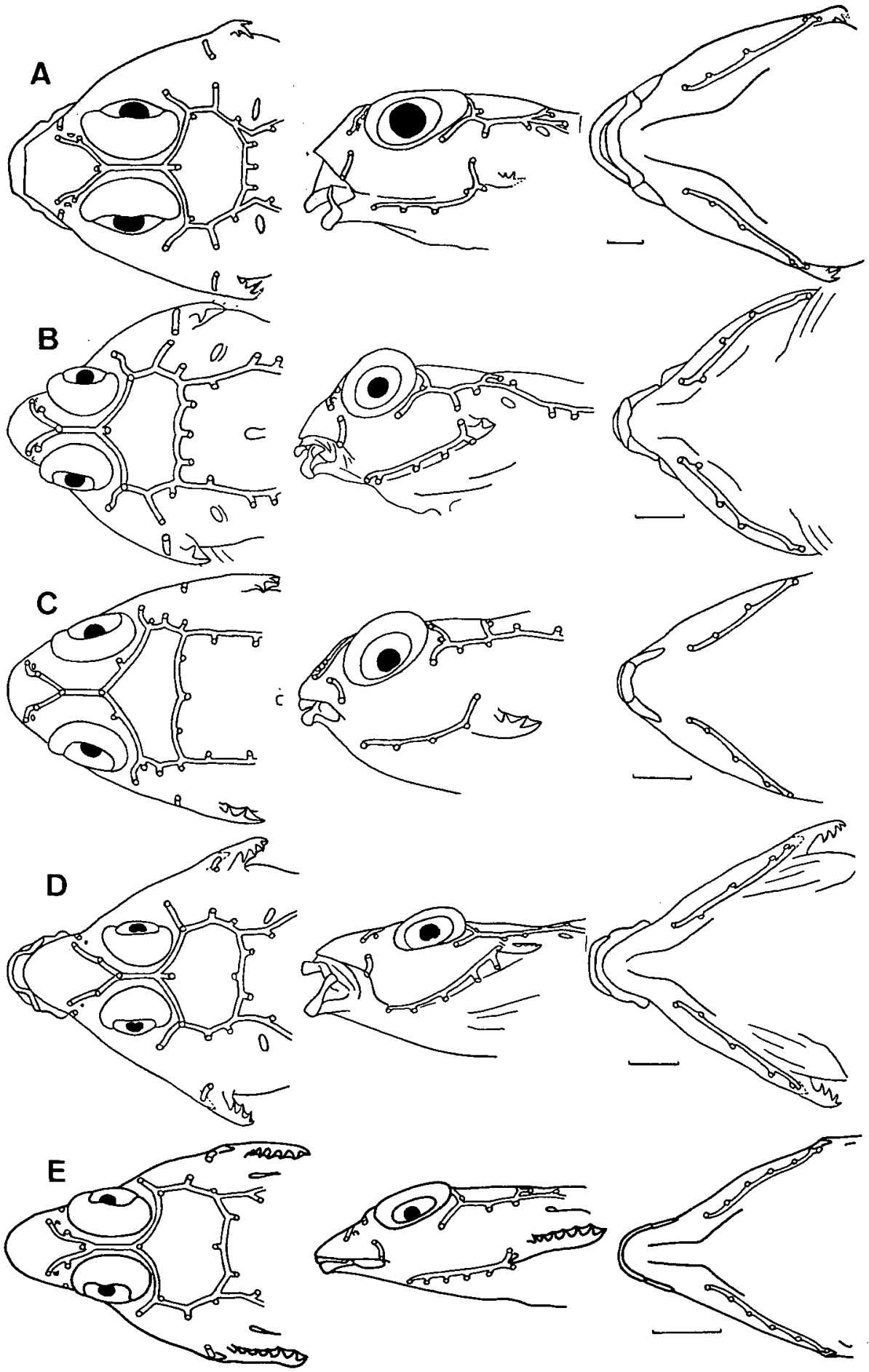

Fig. 24. The cephalic lateral line in five callionymid species. A, Callionymus maculatus; B, Neosynchiropus ocellatus; C, Pterosynchiropus splendidus; D, Paradiplogrammus calliste; E, Diplogrammus goramensis. Left, dorsal view; middle, lateral view; right, ventral view. Scales indicate $5 \mathrm{~mm}$. 


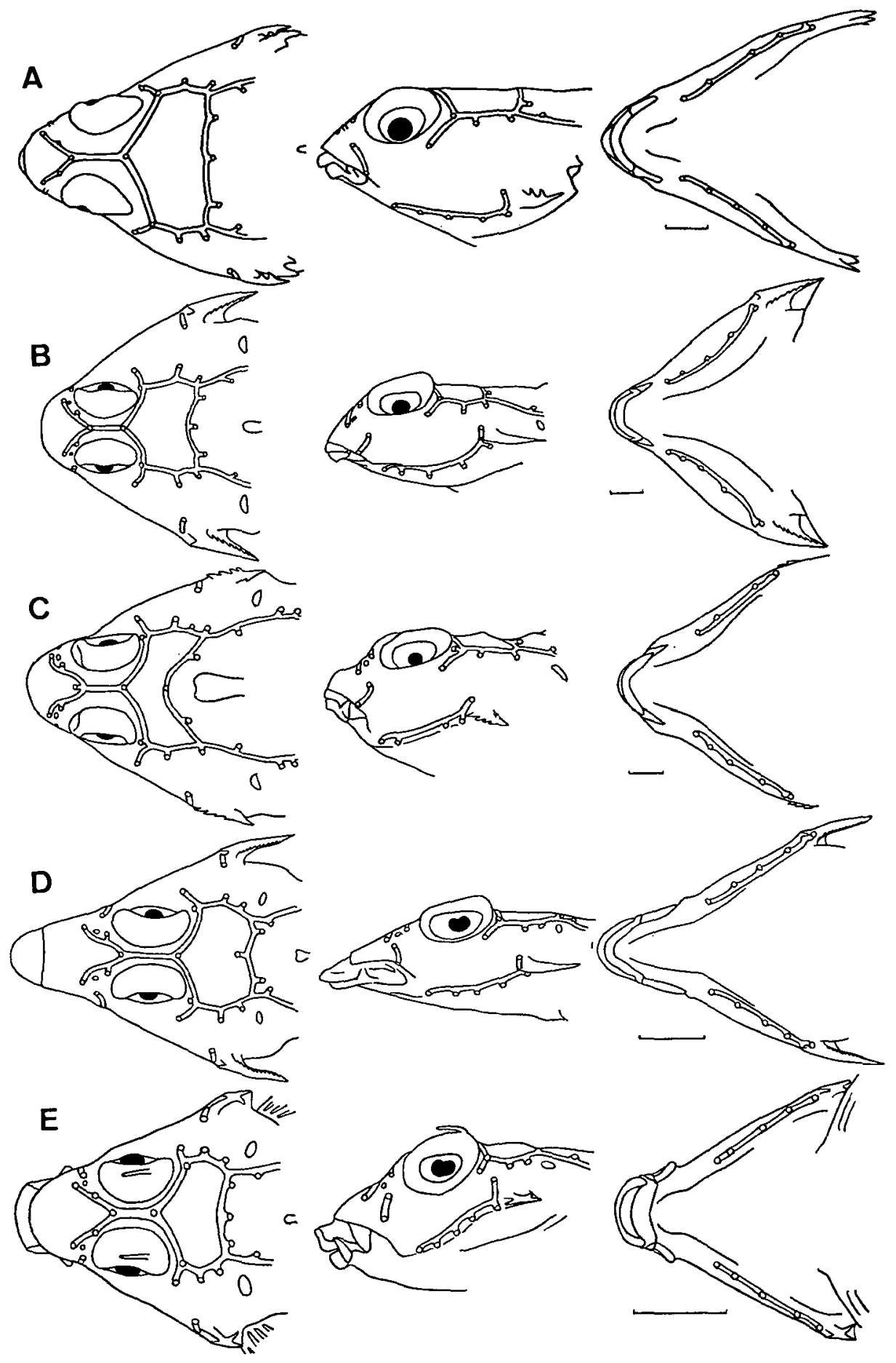

Fig. 25. The cephalic lateral line in five callionymid species. A, Synchiropus ornatus; B, Orbonymus rameus; C, Dactylopus dactylopus; D, Pseudocalliurichthys xanthosemeion; E, Anaora tentaculata. Left, dorsal view; middle, lateral view; right, ventral view. Scales indicate $5 \mathrm{~mm}$. 


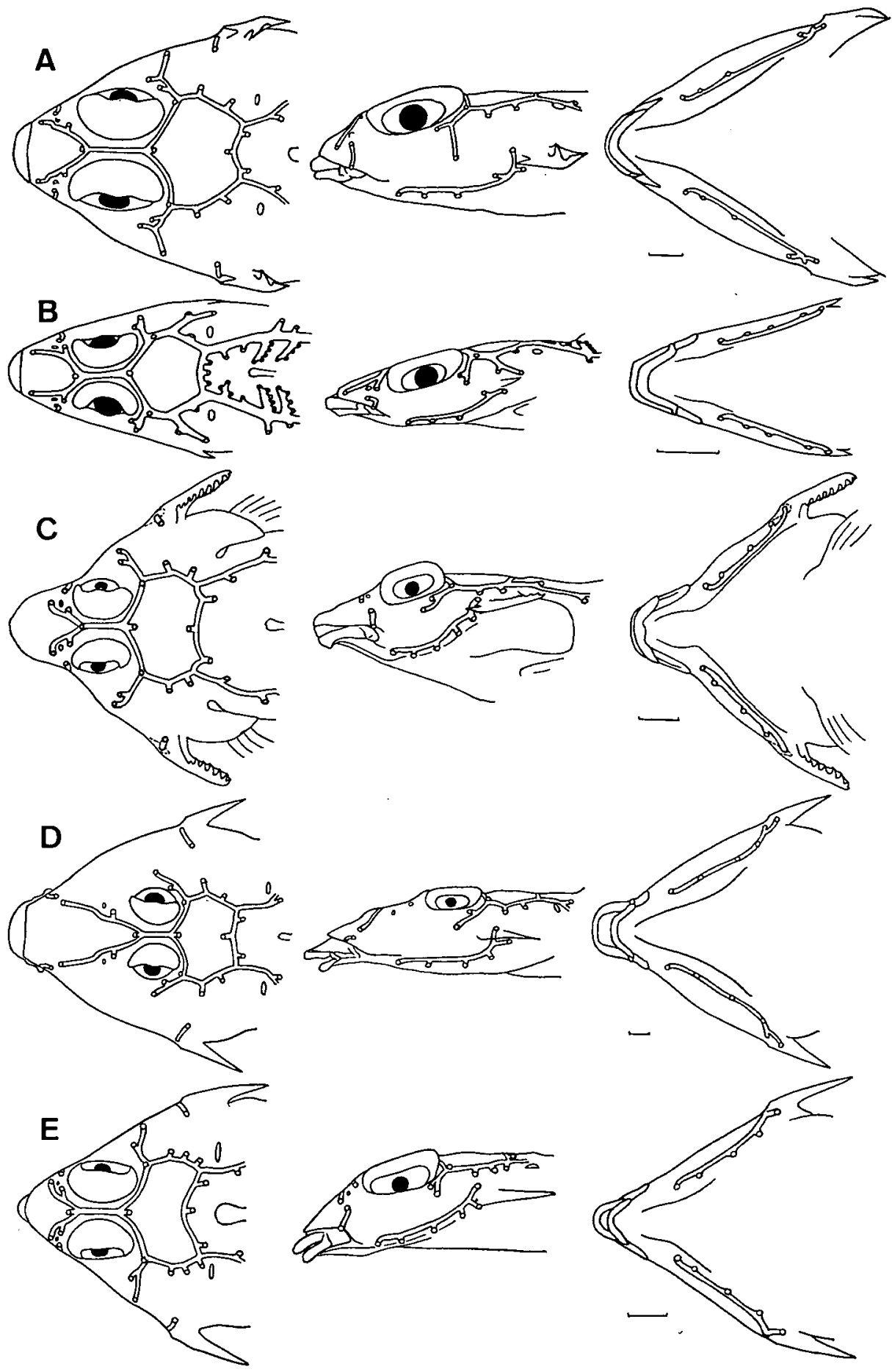

Fig. 26. The cephalic lateral line in five callionymid species. A, Bathycallionymus moretonensis; B, Paracallionymus costatus; C, Diplogrammus xenicus; D, Pseudocalliurichthys goodladi; E, Calliurichthys grossi. Left, dorsal view; middle, lateral view; right, ventral view. Scales indicate $5 \mathrm{~mm}$. 
Paracallionymus, Diplogrammus, Pseudocalliurichthys and Calliurichthys (Fig. 26). A simple infraorbital canal and a very short preoperculo-mandibular canal located near the preopercular spine, Type F, is seen in Diplogrammus (Fig. 27). A supraorbital canal that extends to just after the nasal pore, a simple infraorbital canal and a very short preoperculo-mandibular canal located near the preopercular spine, Type $\mathrm{G}$, is seen in Spinicapitichthys (Fig. 28).
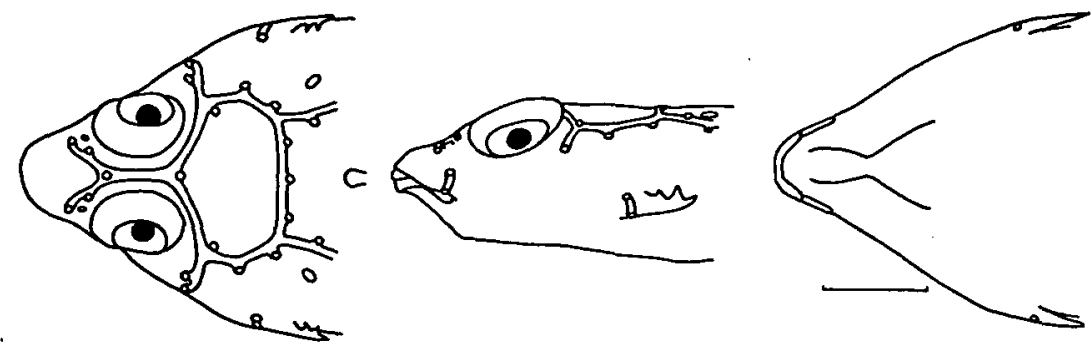

Fig. 27. The cephalic lateral line in Diplogrammus pauciradiatus. Left, dorsal view; middle, lateral view; right, ventral view. Scale indicates $5 \mathrm{~mm}$.
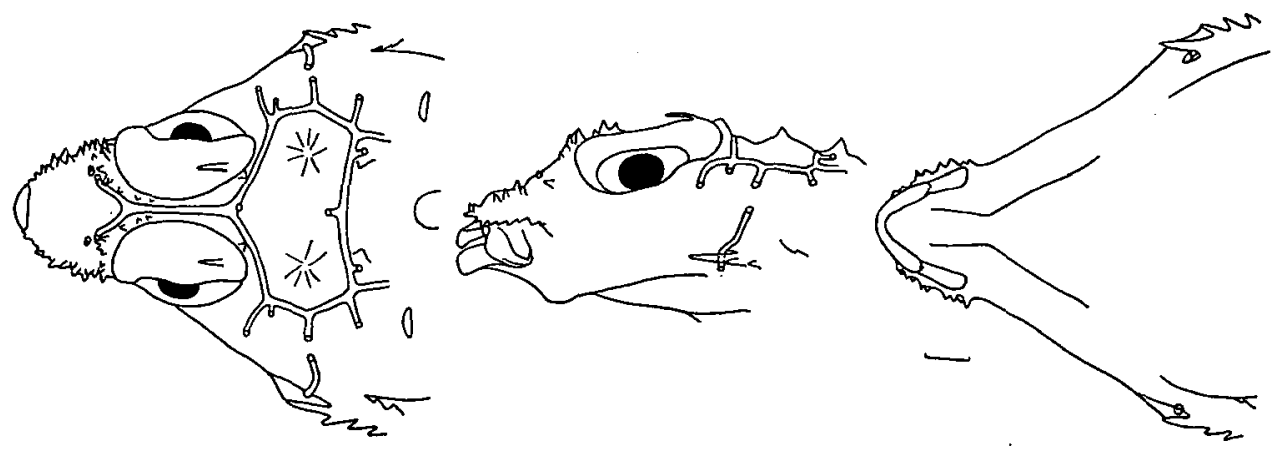

Fig. 28. The cephalic lateral line in Spinicapitichthys spiniceps. Left, dorsal view; middle, lateral view; right, ventral view. Scale indicates $5 \mathrm{~mm}$.

A simple infraorbital canal is more primitive than other types because there are no infraorbital bones to carry it in this family; thus, a divided and extended infraorbital canal must be secondary. The preoperculo-mandibular canal of Type A must be more primitive than the other types because it is like that found in most standard percoid fish with compressed bodies.

The preoperculo-mandibular canal above the preopercular spine disappears in many genera. Because we do not know what shape this missing part had, the character of the cephalic lateral line cannot be used to determine the interrelationships among the genera. It can only be said that Type $A$ is primitive.

Although some genera (Callionymus, Calliurichthys and Diplogrammus) have intrageneric variations in the cephalic lateral line, other genera (Repomucenus and Eleutherochir) are stable. In the latter genera, the cephalic lateral line is one of the generic characters. 
2) Lateral line on the body

The lateral line patterns on the body can be roughly separated into five types. In Type A there are many separated or attached transverse branches on the dorsal surface of the body, and a commissure of the opposite lines on the dorsal surface of the caudal peduncle. Type $\mathrm{A}$ is seen in Synchiropus, Callionymus and Calliurichthys (Fig. 29A-D). In Type B there are many transverse branches on the dorsal surface of the body, and a commissure of the opposite lines on the dorsal surface of the caudal peduncle. Type $\mathrm{B}$ is seen only in Paracallionymus (Fig. 29E). In Type $\mathrm{C}$ there is only the commissure of the opposite lines on the dorsal surface of the caudal peduncle. Type $\mathrm{C}$ is seen in Eocallionymus, Bathycallionymus, Repomucenus and Eleutherochir (Fig. 29F-I). In Type D there are no transverse branches on the dorsal surface of the body, and no commissure of the opposite lines on the dorsal surface of the caudal peduncle. Type D is seen in Foetorepus, Minysynchiropus, Diplogrammus, Paradiplogrammus, Neosynchiropus, Pterosynchiropus, Orbonymus, Dactylopus, Pseudocalliurichthys, Spinicapitichthys and Anaora (Fig. 29J). In Type E the opposite line is interconnected by the transverse branches on both dorsal and ventral surfaces of the caudal
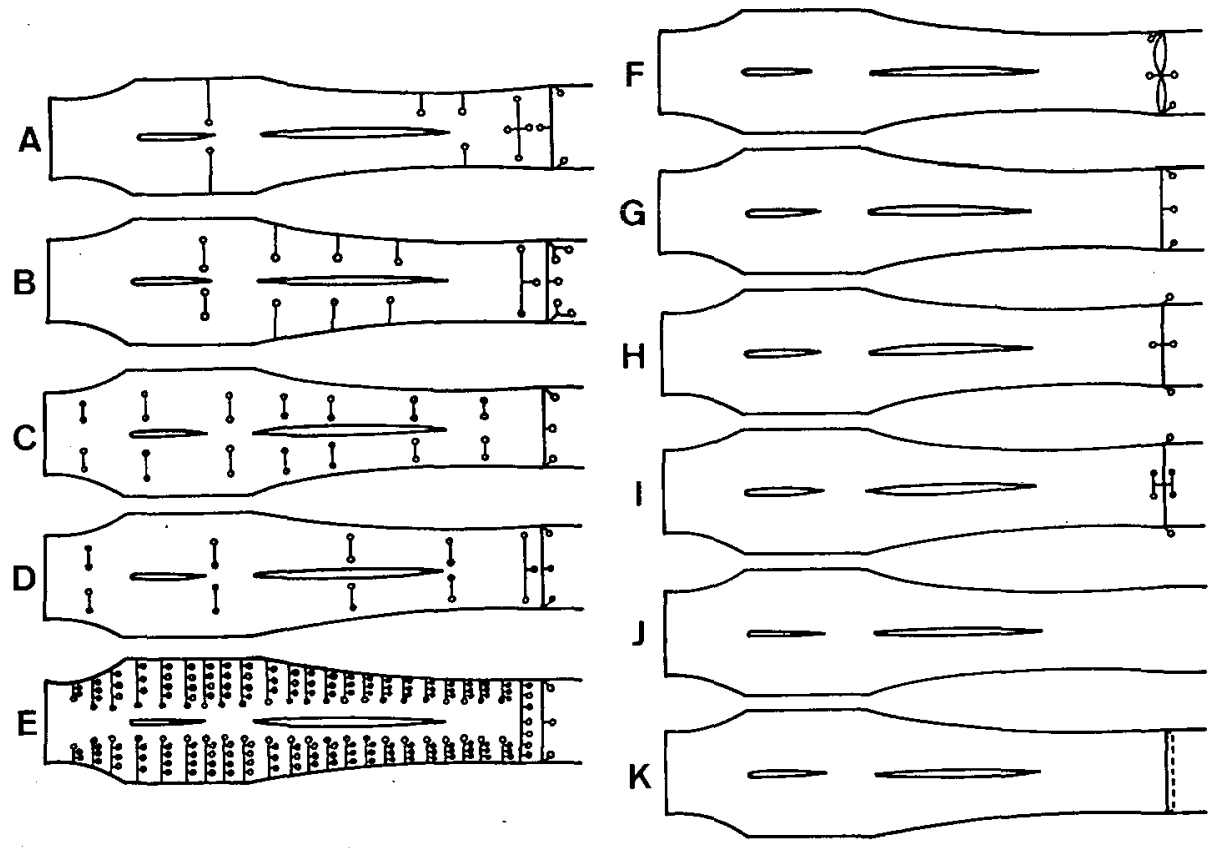

Fig. 29. Diagrammatic illustration showing the lateral line on callionymid body. A, Synchiropus; B, Callionymus (except C. risso and C.pusillus); C, Callionymus risso and C. pusillus; D, Calliurichthys (except C. grossi and C. sp.); E, Paracallionymus; F, Eocallionymus; G, Bathycallionymus; $\mathrm{H}$, Repomucenus (except $R$. huguenini, $R$. fllamentosus, $R$. longi, $R$. brunneus, $R$. punctilateralis and $R$. virgis) and Eleutherochir; I, Repomucenus huguenini, $R$. flamentosus $R$. longi, $R$. brunneus, $R$. punctilateralis and $R$. virgis; J, Anaora, Foetorepus, Minysynchiropus, Diplogrammus, Paradiplogrammus, Neosynchiropus, Pterosynchiropus, Orbonymus, Dactylopus, Pseudocalliurichthys, Spinicapitichthys (exceptt S. oxycephalus), Calliurichthys grossi and Calliurichthys sp.; K, Spinicapitichthys oxycephaius and Calliurichthys neptunius. 
peduncle. Type E is seen in Calliurichthys and Spinicapitichthys (Fig. 29K)

It is difficult to determine which types of lateral line on the body are advanced. Three differentiations can be deduced: 1. Type $\mathrm{D}$ is the most primitive. Type $\mathrm{C}$, A, B being successive derivations. Type $E$ is derived from Type $G ; 2$. Types $B$ and C are derived from Type A, and Types D and E from Type C; 3. Types A, D and $\mathbf{E}$ are derived from Type $\mathbf{C}$, and Type $\mathbf{B}$ from Type A. Types $\mathbf{B}$ and $\mathrm{E}$ could not be the origin, because each is seen in a few genus. But in some genera, lateral line on the body is one of the diagnostic characters.

3) Body size

Gallionymid fishes can be divided into three groups based on their mature size: Foetorepus, Callionymus, Bathycallionymus, Paracallionymus, Calliurichthys and Repomucenus may be $150 \mathrm{~mm}$ or more in standard length; Orbonymus, Dactylopus, Pseudocalliurichthys and Spinicapitichthys may reach $100 \mathrm{~mm}$; Eocallionymus, Eleutherochir, Anaora, Diplogrammus, Paradiplogrammus, Minysynchiropus, Neosynchiropus, Pterosynchiropus and Synchiropus may be $20-70 \mathrm{~mm}$ long.

A comparison of body size with habitat, shows that the six genera which reach a length of $150 \mathrm{~mm}$ or more live on sandy or muddy bottoms, mainly along a continental shelf. Five of the genera (exception Paracallionymus) have large populations world-wide. The three genera that reach a length of $100 \mathrm{~mm}$ live on sandy bottoms along a continental shelf or near islands. The sizes of their populations are small. The eight genera (exception Eleutherochir) which have lengths between 20 and $70 \mathrm{~mm}$ live on the sandy bottoms of coral reefs, in weedy beds, along rocky shores around islands. Their populations are small. Eleutherochir live on sandy bottoms in very shallow waters, in small populations.

4) Body form

The depth-width relationships of the bodies of the 19 genera are shown in Fig. 30. Bathycallionymus, Calliurichthys, Repomucenus, Pseudocalliurichthys and Paracallionymus are strongly depressed and elongate in body form. Since Repomucenus has the

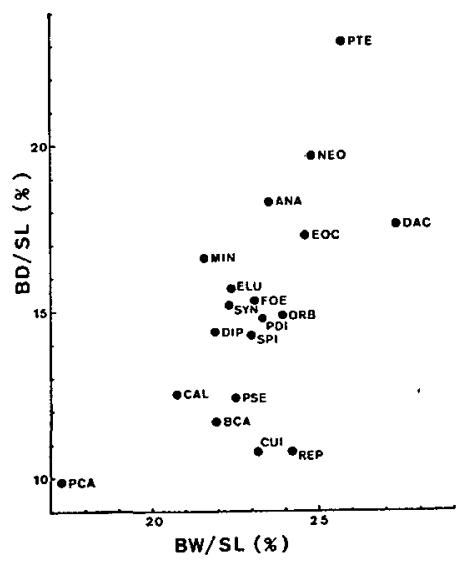

Fig. 30. The relationships between body depth and width in callionymid genera. BD, body depth; BW, body width; SL, standard length; ANA, Anaora; BCA, Bathycallionymus; CAL, Callionymus; GUI, Calliurichthys; DAC, Dactvlopus; DIP, Diplogrammis; ELU, Eleutherochir; EOC, Eocallionymus; FOE, Foetorepus; MIN, Minysynchiropus; NEO, Neosynchiropus; ORB, Orbonymus; PCA, Paracallionymus; PDI, Paradiplogrammus; PSE, Pseudocalliurichthys; PTE, Pterosynchiropus; REP, Repomucenus; SPI., Spinicapitichthys; SYN, Synchiropus. Values are expressed as means between male's and female's averages. 
flattest body of all, it seems to be the most adaptive to inhabit the sand-muddy bottoms on the continental shelf. Foetorepus, Eocallionymus, Paradiplogrammus, Diplogrammus, Minysynchiropus, Synchiropus, Orbonymus, Dactylopus, Spinicapitichthys and Eleutherochir are depressed and moderately elongate. Neosynchiropus, Pterosynchiropus and Anaora are moderately depressed, but not elongate. Since Pterosynchiropus has the most conical body of all, it seems to be the most adaptive to inhabit the coral reefs around islands. Strongly depressed and moderately depressed bodies seem to be derived from depressed one, because most genera have depressed body.

5) Body color

Eocallionymus, Foetorepus calauropomus, Callionymus, Bathycallionymus regani, Anaora, Neosynchiropus, Synchiropus, Orbonymus, Dactylopus and Calliurichthys are marbled light or dark sepia-brown. Diplogrammus, Paradiplogrammus and Spinicapitichthys are marbled dark brown. Eleutherochir is dark brown. Minysynchiropus is creamy white. Bathycallionymus (exception B. regani) is olive-brown. Fresh specimens of Foetorepus (exception $F$. calauropomus) are reddish. Fresh specimens of Pterosynchiropus are colorful. Paracallionymus is uniformly bleached. Repomucenus and Pseudocalliurichthys are marbled brown, like the surface of a sandy bottom.

As judged from the above, the sepia-brown body color is the most primitive because it is found in the most genera. Of all the genera, the body colors of Repomucenus and Pseudocalliurichthys are probably the most adaptive to sandy bottoms.

6) Eye diameter

Foetorepus, Bathycallionymus, Paracallionymus and some species of Callionymus have larger eyes than the others. All live mainly along deep shelf edges, on banks or on seamounts. Therefore, in the callionymid fishes, a large eye is correlated with a deep water habitat.

\section{7) Secondary sexual dimorphism}

In most callionymid species, secondary sexual dimorphism is conspicuous. The secondary sexual characters are found mainly in the unpaired fins of males. In Diplogrammus, Paradiplogrammus, Minysynchiropus, Neosynchiropus Paracallionymus, Pterosynchiropus, Orbonymus, Dactylopus Pseudocalliurichthys, and Repomucenus, the first dorsal fin is a conspicuously large secondary sexual character of the males. In Callionymus and Bathycallionymus, the second dorsal and anal fins are markedly expanded.

In Calliurichthys and Spinicapitichthys, the caudal fin is very elongated. Although secondary sexual dimorphism exists in Foetorepus, Eocallionymus, and Anaora, no markedly conspicuous unpaired fin is present. In Eleutherochir, secondary sexual dimorphism is rare. Secondary sexual dimorphism could not be studied in Synchiropus because of lack of specimens.

Male's conspicuous first dorsal fin in Repomucenus valenciennei (=Callionymus flagris in their paper) and $R$. richardsonii ( $=C$. richardsoni) has a role in distinguishing species and in attracting the female (Takita and Okamoto, 1979). This also is 
Table 2. Proportional measurements as the percent of standard length in genera of the Callionymidae. Data show ranges; the means are in parentheses.

\begin{tabular}{|c|c|c|c|c|c|c|}
\hline \multirow[b]{2}{*}{ Sex } & \multicolumn{2}{|c|}{ Callionymus } & \multicolumn{2}{|c|}{ Bathycallionymus } & \multicolumn{2}{|c|}{ Foetorepus } \\
\hline & male & female & male & female & male & female \\
\hline No. species (NOS) & 5 & $\dot{5}$ & 5 & 5 & 8 & 6 \\
\hline Sttandard length (mm) (SL) & $31.6-178.5$ & $28.8-147.2$ & $71.7-157.5$ & $67.2-171.4$ & $47.4-185.7$ & $27.4-156.8$ \\
\hline Body width (BW) & $17.8-22.3(20.2)$ & $18.0-26.7(22.9)$ & $19.6-22.1(21.1)$ & $20.8-24.0(22.7)$ & $19.3-24.6(22.7)$ & $21.2-26.6(23.5)$ \\
\hline Body depth (BD) & $10.8-12.3(11.8)$ & $12.8-15.0(13.6)$ & $10.9-11.8(11.2)$ & $11.4-13.1(12.1)$ & $12.6-16.7(15.3)$ & $14.5-16.8(15.2)$ \\
\hline Caudal peduncle depth (CPD) & $3.7-5.5(4.7)$ & $3.8-\quad 6.0(4.8)$ & $3.6-4.1(3.8)$ & $3.4-\quad 4.2(3.8)$ & $4.0-\quad 6.9(5.9)$ & $4.7-6.7(5.5)$ \\
\hline Predorsal length (PDL) & $29.7-35.0(32.0)$ & $32.8-35.0(33.8)$ & $26.4-28.2(27.4)$ & $28.4-29.5(29.0)$ & $26.7-33.3(30.1)$ & $27.0-34.3(30.9)$ \\
\hline Caudal fin length (CFL) & $24.2-51.0(31.7)$ & $21.7-28.7(24.9)$ & $30.3-48.5(41.1)$ & $31.5-55.6(38.1)$ & $26.9-61.0(46.4)$ & $28.2-37.5(33.0)$ \\
\hline Head length (HL) & $24.2-25.7(24.6)$ & $24.3-25.7(24.8)$ & $23.6-25.5(24.4)$ & $25.1-25.8(25.4)$ & $27.8-31.2(28.8)$ & $27.2-30.3(28.7)$ \\
\hline Eye diameter (ED) & $7.0-9.5(8.4)$ & $7.0-9.9(8.8)$ & $8.9-9.2(9.1)$ & $9.0-10.1(9.5)$ & $8.8-13.1(10.6)$ & $10.4-13.0(11.4)$ \\
\hline Snout length (SNL) & $8.2-12.7(9.8)$ & $7.6-10.9(9.5)$ & $7.8-9.3(8.4)$ & $8.0-9.2(8.5)$ & $7.6-10.1(9.0)$ & $5.5-9.7(8.1)$ \\
\hline Upper jaw length (UJL) & $7.5-10.1(9.1)$ & $7.1-10.9(8.7)$ & $6.7-\quad 7.9(7.5)$ & $7.4-8.1(7.7)$ & $8.1-10.8(9.1)$ & $7.6-9.9(8.6)$ \\
\hline Interorbital width (IOW) & $1.3-2.3(1.9)$ & $1.6-2.1(1.8)$ & $1.1-\quad 1.5(1.3)$ & $1.1-1.6(1.2)$ & $0.6-2.8(1.9)$ & $0.7-2.7(1.5)$ \\
\hline 1st dorsal spine length (DS1) & $7.5-54.4(28.1)$ & $7.4-13.2(10.2)$ & $17.2-32.7(23.3)$ & $15.7-26.5(20.3)$ & $20.1-48.0(30.3)$ & $16.7-36.5(23.0)$ \\
\hline 2nd dorsal spine length (DS2) & $6.5-27.4(16.7)$ & $5.7-12.5(9.3)$ & $14.1-19.7(17.6)$ & $13.9-18.4(15.9)$ & $14.9-44.2(24.1)$ & $13.8-20.0(17.0)$ \\
\hline 3rd dorsal spine length (DS3) & $4.5-26.7(13.5)$ & $4.3-10.2(7.5)$ & $13.5-18.9(16.6)$ & $13.2-16.3(14.8)$ & $13.9-35.8(19.4)$ & $13.2-16.6(14.7)$ \\
\hline 4th dorsal spine length (DS4) & $6.2-13.9(9.5)$ & $3.6-\quad 6.9(5.3)$ & $9.6-11.1(10.1)$ & $8.1-11.7(9.1)$ & $9.7-24.4(13.9)$ & $10.7-12.4(11.3)$ \\
\hline 1st dorsal ray length (FDR) & $16.1-70.3(32.0)$ & $15.4-18.8(16.8)$ & $15.3-23.0(19.1)$ & $16.2-18.8(17.5)$ & $17.7-35.8(25.6)$ & $16.5-23.7(20.2)$ \\
\hline Last dorsal ray length (LDR) & $13.3-33.7(24.5)$ & $9.5-13.5(11.2)$ & $15.8-21.4(19.2)$ & $14.9-19.2(17.3)$ & $18.6-32.6(24.6)$ & $13.8-22.4(19.0)$ \\
\hline 1st anal ray length (FAR) & $7.4-9.0(8.5)$ & $7.8-8.5(8.0)$ & $7.4-11.4(9.7)$ & $7.3-9.5(8.9)$ & $7.2-10.7(9.2)$ & $8.2-9.5(8.7)$ \\
\hline Last anal ray length (LAR) & $11.5-22.8(16.4)$ & $9.5-11.9(11.2)$ & $13.8-19.3(16.3)$ & $12.5-14.9(13.5)$ & $16.1-25.5(20.6)$ & $14.3-20.5(16.6)$ \\
\hline Pectoral fin length (PFL) & $18.5-21.9(21.6)$ & $18.4-26.6(21.9)$ & $17.9-18.9(18.5)$ & $17.9-19.5(18.7)$ & $20.1-26.3(23.8)$ & $19.2-22.3(21.0)$ \\
\hline Pelvic fin length (PVL) & $24.0-28.0(26.8)$ & $23.1-30.6(26.4)$ & $23.1-26.2(24.8)$ & $23.5-25.9(24.3)$ & $25.9-32.7(29.5)$ & $26.0-30.4(27.7)$ \\
\hline Preopercular spine length (PSL) & $3.8-4.2(4.1)$ & $3.6-4.3(4.0)$ & $4.8-\quad 6.0(5.5)$ & $5.0-7.3(6.2)$ & & \\
\hline Anal papilla length (APL) & $2.4-5.0(3.7)$ & $0.3-2.1(1.0)$ & $1.8-\quad 3.2(2.6)$ & $0.8-1.1(1.0)$ & $1.0-2.7(2.0)$ & $0.7-1.0(0.9)$ \\
\hline
\end{tabular}


Table 2. Continued.

\begin{tabular}{|c|c|c|c|c|c|c|c|c|c|c|}
\hline \multirow[b]{2}{*}{ Sex } & \multicolumn{2}{|c|}{ Eocallionymus } & Paracallionymus & \multicolumn{2}{|c|}{ Neosynchiropus } & \multirow{2}{*}{$\frac{\text { Pterosynchiropus }}{\text { female }}$} & \multicolumn{2}{|c|}{ Minysynchiropus } & \multicolumn{2}{|c|}{ Paradiplogrammus } \\
\hline & male & female & male & male & female \& young & & male & female & male & female \\
\hline NOS & 1 & 1 & 1 & 3 & 3 & 2 & 1 & 1 & 4 & 5 \\
\hline SL & $43.9-68.7$ & $26.0-48.2$ & $38.0-46.1$ & $18.0-78.7$ & $9.6-55.0$ & $33.6-52.9$ & $15.2-22.1$ & $21.5-23.8$ & $17.9-66.8$ & $14.9-57.6$ \\
\hline BW & 23.7 & 25.5 & 17.3 & $21.0-25.2(23.5)$ & $25.2-27.1(26.0)$ & $24.3-27.0(25.7)$ & 20.4 & 22.7 & $20.7-23.5(22.1)$ & $23.0-26.0(24.4)$ \\
\hline $\mathrm{BD}$ & 17.0 & 17.6 & 9.9 & $16.1-20.0(18.6)$ & $20.0-21.9(20.7)$ & $21.1-25.0(23.1)$ & 15.9 & 17.3 & $13.2-16.2(14.4)$ & $13.6-16.6(15.2)$ \\
\hline CPD & 7.6 & 7.8 & 3.8 & $8.9-9.9(9.3)$ & $9.0-10.9(9.8)$ & $15.3-17.1(16.2)$ & 7.2 & 7.5 & $6.1-8.1(7.1)$ & $5.9-8.2(6.9)$ \\
\hline PDL & 32.6 & 35.8 & 31.3 & $28.3-33.3(30.9)$ & $32.2-34.7(33.5)$ & $36.1-38.8(37.5)$ & 29.2 & 31.4 & $29.7-31.5(30.4)$ & $32.2-36.3(33.8)$ \\
\hline GFL & 36.0 & 29.6 & - & $29.9-32.9(31.4)$ & $28.9-33.0(31.2)$ & $28.2-32.8(30.5)$ & 30.3 & 27.0 & $26.9-37.5(33.0)$ & $24.7-30.4(27.8)$ \\
\hline HL & 27.6 & 29.6 & 27.0 & $25.2-31.1(28.6)$ & $25.6-30.4(28.6)$ & $31.0-32.4(31.7)$ & 28.0 & 27.4 & $26.1-27.6(26.9)$ & $26.9-29.3(28.1)$ \\
\hline ED & 9.0 & 10.5 & 10.0 & $8.1-12.8(10.1)$ & $8.2-11.2(10.0)$ & $10.2-12.7(11.5)$ & 9.9 & 10.3 & $8.4-9.7(8.9)$ & $9.1-12.0(10.2)$ \\
\hline SNL & 9.9 & 9.7 & 8.6 & $6.7-10.3(9.1)$ & $9.1-11.9(10.1)$ & $11.4-11.5(11.5)$ & 9.9 & 8.6 & $8.8-9.7(9.2)$ & $7.4-12.0(9.5)$ \\
\hline UJL & 8.2 & 8.0 & 10.5 & $7.7-8.9(8.3)$ & $7.6-8.7(8.1)$ & $8.2-9.3(8.8)$ & 8.6 & 8.6 & $7.6-8.8(8.2)$ & $7.7-10.0(8.5)$ \\
\hline IOW & 2.7 & 2.7 & 1.2 & $1.1-4.2(2.9)$ & $1.9-3.3(2.6)$ & $7.1-9.3(8.2)$ & 1.6 & 1.5 & $1.5-1.9(1.8)$ & $1.2-2.0(1.7)$ \\
\hline DS1 & 18.1 & 9.2 & 28.2 & $29.7-59.4(47.5)$ & $14.8-28.3(19.2)$ & $17.6-19.9(18.8)$ & 41.3 & 14.1 & $28.1-38.6(35.2)$ & $11.1-19.9(15.9)$ \\
\hline DS2 & 18.7 & 9.7 & 30.8 & $10.6-56.1(32.9)$ & $13.6-25.3(18.0)$ & $12.3-14.9(13.6)$ & 42.1 & 14.4 & $25.7-38.0(31.9)$ & $10.5-20.3(15.3)$ \\
\hline DS3 & 17.2 & 7.6 & 31.1 & $5.6-53.4(30.1)$ & $11.6-20.9(15.2)$ & $10.5-12.8(11.7)$ & 40.2 & 13.8 & $31.5-48.0(39.9)$ & $9.0-18.7(14.1)$ \\
\hline DS4 & 7.5 & 3.5 & 10.5 & $3.3-27.1(24.8)$ & $9.0-13.6(10.7)$ & $8.0-9.6(8.8)$ & 28.1 & 8.1 & $18.4-37.3(26.9)$ & $5.7-15.7(9.9)$ \\
\hline FDR & 18.1 & 15.9 & 18.4 & $18.9-19.3(19.1)$ & $17.6-18.4(18.0)$ & $19.7-20.1(19.9)$ & 19.0 & 17.2 & $19.4-20.4(19.7)$ & $19.7-20.5(20.0)$ \\
\hline LDR & 23.1 & 12.7 & 15.0 & $21.1-25.4(23.3)$ & $17.3-18.4(17.9)$ & $15.7-16.0(15.9)$ & 19.8 & 15.7 & $18.3-23.3(21.1)$ & $13.4-16.8(15.8)$ \\
\hline FAR & 9.0 & 8.2 & 7.9 & $10.0-10.7(10.5)$ & $10.7-11.2(10.9)$ & $11.1-14.0(12.6)$ & 10.3 & 10.0 & $10.1-10.8(10.3)$ & $8.3-10.6(10.1)$ \\
\hline LAR & 19.7 & 14.3 & 13.4 & $19.4-19.8(19.6)$ & $16.4-19.2(17.8)$ & $14.1-18.6(16.1)$ & 15.2 & 128 & $16.8-22.9(20.0)$ & $13.3-15.6(14.9)$ \\
\hline PFL & 19.8 & 19.3 & 19.2 & $23.6-25.5(24.6)$ & $22.2-23.7(23.0)$ & $20.2-20.6(20.4)$ & 24.2 & 24.3 & $23.0-24.5(24.0)$ & $20.3-24.6(22.6)$ \\
\hline PVL & 30.0 & 31.1 & 26.9 & $28.3-36.4(33.2)$ & $31.9-36.7(34.7)$ & $27.1-29.8(28.5)$ & 37.2 & 37.6 & $29.6-34.8(32.3)$ & $29.3-32.9(30.8)$ \\
\hline PSL & - & - & - & $(3.4)$ & $(3.8)$ & 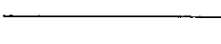 & - & - & $5.1-5.9(5.5)$ & $5.8-10.3(7.3)$ \\
\hline APL & 1.2 & 0.6 & 2.4 & $2.3-2.4(2.4)$ & $(1.2)$ & $(1.0)$ & 2.7 & 0.6 & $2.0-4.0(3.3)$ & $0.5-0.8(0.7)$ \\
\hline
\end{tabular}


Table 2. Continued.

\begin{tabular}{|c|c|c|c|c|c|c|c|c|c|c|}
\hline \multirow[b]{2}{*}{ Sex } & \multicolumn{2}{|c|}{ Diplogrammis } & \multirow{2}{*}{$\frac{\text { Synchiropus }}{\text { male }}$} & \multicolumn{2}{|c|}{ Orbonymus } & \multirow{2}{*}{$\frac{\text { Dactylopus }}{\text { female }}$} & \multicolumn{2}{|c|}{ Calliurichthys } & \multicolumn{2}{|c|}{ Pseudocalliurichthys } \\
\hline & male & female & & male & female & & male & female & male & female \\
\hline NOS & 4 & 3 & 1 & 1 & 1 & 1 & 4 & 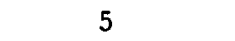 & 3 & 2 \\
\hline SL & $14.0-79.7$ & $11.8-78.5$ & 70.4 & $123.9-131.8$ & 126.0 & $80.2-94.5$ & $41.7-219.2$ & $28.4-166.9$ & $39.0-126.3$ & $20.8-121.9$ \\
\hline BW & $17.1-27.7(21.9)$ & $19.8-25.3(21.8)$ & 22.3 & 24.0 & 23.8 & 27.3 & $20.4-24.3(22.1)$ & $21.8-26.1(24.3)$ & $17.3-23.5(21.0)$ & $23.3-24.4(23.9)$ \\
\hline $\mathrm{BD}$ & $12.0-16.6(14.3)$ & $12.0-17.5(14.4)$ & 15.2 & 14.1 & 15.6 & 17.6 & $9.1-11.3(10.2)$ & $9.0-14.8(11.3)$ & $10.8-13.0(11.7)$ & $11.1-15.1(13.1)$ \\
\hline CPD & $6.0-6.8(6.5)$ & $5.9-7.7(6.7)$ & 7.5 & 6.9 & 7.5 & 7.5 & $4.2-\quad 5.4(4.7)$ & $4.8-\quad 6.3(5.3)$ & $6.0-6.3(6.2)$ & $5.8-6.4(6.1)$ \\
\hline PDL & $28.3-33.5(30.7)$ & $30.0-38.2(32.9)$ & 29.1 & 22.5 & 25.6 & 23.0 & $25.9-30.9(28.3)$ & $22.9-34$ & $30.3-36.5(32.7)$ & $32.1-39.4(35.8)$ \\
\hline CFL & $28.6-33.8(31.7)$ & $27.7-30.1(28.9)$ & 35.8 & 39.7 & 44.0 & 38.4 & $54.7-99.2(74.7)$ & $33.1-64.7(4$ & $48.4-60.1(52.6)$ & $32.6-43.0(37.8)$ \\
\hline HL & $24.9-29.9(27.1)$ & $25.2-32.2(26.1)$ & 28.3 & 23.2 & 24.8 & 28.1 & $23.3-27.3(25.6)$ & $23.2-28.9(25.7)$ & $27.2-32.0(29.5)$ & $30.3-33.6(32.0)$ \\
\hline ED & $7.2-10.9(9.2)$ & $8.4-12.2(9.8)$ & 7.8 & 7.4 & 8.0 & 8.2 & $7.7-8.6(8.2)$ & $7.5-12.0(9.1)$ & $6.5-\quad 7.9(7.4)$ & $6.4-9.8(8.1)$ \\
\hline SNL & $8.5-9.5(9.1)$ & $8.6-10.8(9.5)$ & 7.1 & 7.2 & 7.1 & 9.5 & $8.9-11.3(10.4)$ & $8.3-11.0(9.6)$ & $13.6-15.5(14.9)$ & $14.8-15.0(14.9)$ \\
\hline UJL & $8.6-9.3(8.9)$ & $8.0-8.6(8.3)$ & 7.1 & 6.6 & 6.5 & 8.2 & $7.6-10.0(9.1)$ & $6.3-9.5(8.2)$ & $9.3-12.2(10.8)$ & $9.8-11.9(10.9)$ \\
\hline IOW & $0.7-2.0(1.5)$ & $1.6-1.9(1.7)$ & 3.8 & 3.7 & 2.5 & 3.5 & $1.0-1.5(1.2)$ & $0.7-1.8(1.0)$ & $1.1-1.8(1.5)$ & $1.5-2.1(1.8)$ \\
\hline DS1 & $24.8-40.1(33.9)$ & $13.7-17.5(15.6)$ & 19.3 & 71.0 & 61.6 & 44.7 & $24.2-48.3(37.1)$ & $17.7-52.3(27.6)$ & $18.2-61.3(39.8)$ & $10.0-42.5(26.3)$ \\
\hline DS2 & $12.1-38.6(23.7)$ & $11.2-15.3(13.5)$ & 17.5 & 69.0 & 60.5 & 40.0 & $12.7-21.8(15.8)$ & $15.1-30.4(19.3)$ & $14.9-38.3(29.9)$ & $10.6-14.3(12.5)$ \\
\hline DS3 & $10.3-39.0(22.9)$ & $9.8-13.0(11.3)$ & 21.7 & 64.4 & - & 29.8 & $12.9-16.7(14.6)$ & $14.9-26.1(18.6)$ & $11.8-15.0(13.1)$ & $9.7-11.7(10.7)$ \\
\hline DS4 & $7.8-25.3(15.1)$ & $4.9-7.7(6.0)$ & 20.0 & 60.6 & 51.6 & 18.1 & $9.0-11.7(9.7)$ & $9.2-18.9(12.1)$ & $9.1-10.0(9.4)$ & $7.0-8.0(7.5)$ \\
\hline FDR & $17.3-19.7(18.2)$ & $16.9-20.0(18.7)$ & 19.3 & 21.0 & 23. & 23.5 & $15.3-17.2(16.0)$ & $16.1-18.9(17.6)$ & $15.5-19.5(17.2)$ & $16.4-17.9(17.2)$ \\
\hline $\mathrm{CDR}$ & $20.6-28.8(24.8)$ & $12.4-18.2(15.9)$ & 22.7 & 25.0 & 26.2 & 22.7 & $19.2-21.5(20.6)$ & $17.3-25.7(20.8)$ & $19.0-27.7(24.2)$ & $16.3-24.4(20.4)$ \\
\hline FAR & $9.1-10.3(9.8)$ & $10.5-12.2(11.2)$ & 10.1 & 10.2 & 10.7 & 12.6 & $7.6-9.1(8.4)$ & $8.6-10.0(9.5)$ & $9.3-10.3(9.9)$ & $10.2-10.6(10.4)$ \\
\hline LAR & $15.9-21.2(18.7)$ & $11.9-15.7(13.8)$ & 20.7 & 23.5 & 25.5 & 23.6 & $15.6-19.6(16.8)$ & $13.3-19.9(17.0)$ & $18.9-20.6(19.6)$ & $15.2-17.0(16.1)$ \\
\hline PFL & $21.7-27.8(24.1)$ & $21.9-23.2(22.5)$ & 24.4 & 28.2 & 25.4 & 23.0 & $18.3-20.7(19.6)$ & $19.1-22.3(20.4)$ & $19.7-22.1(20.7)$ & $19.4-22.2(20.8)$ \\
\hline PVL & $29.3-36.7(33.0)$ & $29.5-32.5(31.3)$ & 32.5 & 38.4 & 36.2 & 43.7 & $25.5-31.3(28.3)$ & $28.5-31.7(29.9)$ & $26.7-30.5(28.4)$ & $26.8-31.8(29.3)$ \\
\hline PSL & $8.6-8.9(8.8)$ & $9.6-10.5(10.1)$ & - & 8.6 & 8.7 & 7.2 & $5.3-8.0(6.6)$ & $7.6-8.9(8.1)$ & $5.5-8.1(6.8)$ & $7.7-8.4(8.1)$ \\
\hline APL & $2.1-4.7(3.1)$ & $0.6-1.8(1.2)$ & 2.7 & 2.0 & 1.0 & 0.6 & $1.7-4.0(2.6)$ & $0.7-\quad 1.3(1.0)$ & $1.3-2.8(2.1)$ & $0.4-0.7(0.6)$ \\
\hline
\end{tabular}


Table 2. Continued.

\begin{tabular}{|c|c|c|c|c|c|c|c|c|}
\hline \multirow[b]{2}{*}{ Sex } & \multicolumn{2}{|c|}{ Repomucenus } & \multicolumn{2}{|c|}{ Spinicapitichthys } & \multicolumn{2}{|c|}{ Anaora } & \multicolumn{2}{|c|}{ Eleutherochir } \\
\hline & male & female & male & female & male & female & male & female \& young \\
\hline NOS & 27 & 21 & 2 & 1 & 1 & 1 & 2 & 2 \\
\hline SL & $23.4-184.0$ & $21.2-171.4$ & $90.8-99.7$ & $86.4-100.2$ & $27.0-38.5$ & $19.0-34.9$ & $37.5-66.3$ & $19.7-54.1$ \\
\hline BW & $19.9-28.9(23.8)$ & $21.7-29.7(24.5)$ & $22.0-25.6(23.8)$ & 22.1 & 22.5 & 24.4 & $16.2-24.9(20.6)$ & $18.2-29.9(24.1)$ \\
\hline $\mathrm{BD}$ & $8.0-12.0(10.4)$ & $10.3-12.8(11.2)$ & $12.9-17.2(15.1)$ & 13.5 & 17.5 & 19.1 & $10.3-17.2(13.8)$ & $12.2-22.8(17.5)$ \\
\hline CPD & $4.3-6.2(5.0)$ & $4.4-5.6(5.0)$ & $5.4-5.8(5.6)$ & 5.4 & 7.9 & 8.4 & $5.4-9.5(7.5)$ & $5.3-11.7(8.5)$ \\
\hline PDL & $26.1-38.5(31.7)$ & $28.7-36.9(32.4)$ & $27.9-29.4(28.7)$ & 28.4 & 36.8 & 38.8 & $41.2(41.2)$ & $48.2(48.2)$ \\
\hline CFL & $23.6-67.1(36.7)$ & $26.7-37.6(30.1)$ & $69.1-94.0(81.6)$ & 61.4 & 51.7 & 33.3 & $23.6-27.6(25.6)$ & $23.7-35.0(29.4)$ \\
\hline HL & $23.1-2.9 .3(25.6)$ & $22.8-27.9(25.8)$ & $28.4-33.5(31.0)$ & 28.8 & 31.7 & 32.3 & $25.0-33.2(29.1)$ & $26.0-43.7(34.9)$ \\
\hline $\mathrm{ED}$ & $6.2-10.1(8.1)$ & $6.5-11.2(8.3)$ & $9.4-11.7(10.6)$ & 10.2 & 11.0 & 11.1 & $5.7-7.2(6.5)$ & $5.7-11.2(8.5)$ \\
\hline SNL & $6.0-12.4(9.7)$ & $6.8-12.5(9.7)$ & $9.8-13.3(11.6)$ & 9.4 & 14.2 & 13.2 & $7.3-10.9(9.1)$ & $7.5-13.2(10.4)$ \\
\hline UJL & $6.3-10.0(8.4)$ & $6.3-10.0(8.3)$ & $7.0-10.2(8.6)$ & 6.9 & 10.5 & 10.1 & $6.9-11.8(9.4)$ & $7.4-14.7(11.1)$ \\
\hline IOW & $1.0-\quad 3.0(1.7)$ & $1.1-2.6(1.6)$ & $1.0-2.0(1.5)$ & 0.9 & 3.4 & 3.8 & $3.7-6.6(5.2)$ & $4.1-8.6(6.4)$ \\
\hline DS 1 & $7.2-65.9(29.2)$ & $7.6-28.0(12.8)$ & $21.9-60.5(41.2)$ & 41.6 & 15.2 & 13.6 & $8.3(8.3)$ & $10.2(10.2)$ \\
\hline DS2 & $6.9-72.1(22.4)$ & $6.3-19.1(11.6)$ & $16.0-24.4(20.2)$ & 17.0 & 15.1 & 14.1 & $8.3(8.3)$ & $9.6(9.6)$ \\
\hline DS3 & $3.0-63.6(17.9)$ & $2.7-11.8(9.4)$ & $18.0-25.7(21.9)$ & 17.6 & 13.1 & 11.5 & $7.4(7.4)$ & $8.1(8.1)$ \\
\hline DS4 & $3.5-59.4(12.1)$ & $3.6-10.2(6.1)$ & $11.7-17.0(14.4)$ & 10.8 & 7.6 & 6.1 & $5.3(5.3)$ & $4.1(4.1)$ \\
\hline FDR & $13.7-20.6(16.5)$ & $13.7-19.7(16.8)$ & $20.6-22.2(21.4)$ & 21.5 & 20.6 & 18.5 & $6.9-10.3(8.6)$ & $6.3-10.2(8.3)$ \\
\hline LDR & $9.6-32.9(21.0)$ & $10.6-20.2(16.3)$ & $20.3-21.3(20.8)$ & 19.0 & 20.2 & 13.9 & $8.6-10.7(9.7)$ & $8.3-10.2(9.3)$ \\
\hline FAR & $7.2-10.4(8.6)$ & $7.7-9.9(8.6)$ & $9.6-10.1(9.9)$ & 9.8 & 13.4 & 12.7 & $5.4-8.5(7.0)$ & $7.9-8.6(8.3)$ \\
\hline LAR & $9.0-20.1(13.7)$ & $9.8-14.8(12.4)$ & $19.0-20.1(20.0)$ & 18.5 & 25.0 & 13.9 & $10.1-12.2(11.2)$ & $9.6-10.7(10.2)$ \\
\hline PFL & $17.9-23.6(20.4)$ & $18.0-23.6(20.5)$ & $22.0-23.2(22.6)$ & 22.3 & 23.9 & 21.2 & $21.4-21.6(21.5)$ & $20.8-22.3(21.6)$ \\
\hline PVL & $23.9-31.6(27.8)$ & $24.6-32.0(28.2)$ & $29.2-31.6(30.4)$ & 31.4 & 35.4 & 32.0 & $19.6-23.1(21.4)$ & $18.3-34.5(26.4)$ \\
\hline PSL & $3.3-\quad 9.8(6.7)$ & $4.2-10.8(7.2)$ & $8.0-14.9(11.5)$ & 16.3 & 4.2 & 4.7 & & \\
\hline APL & $0.7-5.5(3.1)$ & $0.5-1.6(1.0)$ & $1.7-3.2(2.5)$ & 0.8 & 2.2 & - & $1.8-2.1(2.0)$ & $0.8(0.8)$ \\
\hline
\end{tabular}


true of the unpaired fins in other species and genera. Thus, secondary sexual dimorphism in the unpaired fins is necessary for the maintenance of populations of species in the animal community. If the types of secondary sexual dimorphism listed above did not vary so widely, they could be used as features of the phylogeny of callionymids.

\section{Summary}

1. A new classification for Callionymidae which includes 19 genera and 139 valid species is proposed. Callionymus, Foetorepus, Paracallionymus, Diplogrammus, Synchiropus, Orbonymus, Dactylopus, Calliurichthys, Repomucenus, Spinicapitichthys, Anaora and Eleutherochir are redefined; Bathycallionymus, Eocallionymus, Neosynchiropus, Pterosynchiropus, Minysynchiropus, Paradiplogrammus and Pseudocalliurichthys are established as new.

2. There are 7 pattern types for the cephalic lateral line, and 5 types for the lateral line on the body. Neither line can be used to determine phylogenetic relationships among the genera; but in some genera, the pattern of the lateral line are a diagnostic character.

3. Dragonets vary in mature size from very small $(20 \mathrm{~mm}$ in standard length) to large $(200 \mathrm{~mm})$.

4. The body form of the callionymid genera vary from almost conical to strongly depressed. Pterosynchiropus has the deepest body and Repomucenus has the most depressed body.

5. The callionymid show a variety of color patterns on their bodies. Marbled sepia-brown color which most genera have is the most primitive, and marbled brown color like the surface of a sandy bottom which Repomucenus and Pseudocalliurichthys have is the most adaptive to benthic life.

6. In most callionymid species, the mature male has conspicuous secondary sexual characters. In some genera the secondary sexual character shows on the first dorsal fin, but it may be manifested in the second and anal fins, or in some cases in the caudal fin.

\section{Acknowledgements}

I express my deep gratitude to Dr. Tamotsu Iwai who, as my major professor at Kyoto University, has been a constant source of help throughout this study and who made a critical reading of the entire manuscript. Special thanks are extended to Dr. Akira Ochiai, professor of Kochi University, who gave me much helpful advice and encouragement; and Dr. Eiji Harada, professor of Seto Marine Biological Laboratory, Kyoto University, who gave me the chance to publish this study.

This study would not have been possible without the generous cooperation of many people. The following persons and institutions lent or gave specimens, or accomodated me during visits: Drs. John R. Paxton, Douglass F. Hoese and Ms. Helen Larson of the Australian Museum; Drs. James E. Böhlke and William F. Smith-Vaniz of the Academy of Natural Sciences of Philadelphia; Mr. Ronald Fricke 
of Braunschweig; Mr. Alwyne Wheeler of British Museum (Natural History); Mr. Akihisa Iwata of Ehime University; Drs. Tetsuya Sato, Hiroshi Hatanaka, Yasuo Nishikawa and Mr. Yuji Uozumi of Far Seas Fisheries Research Laboratory; Dr. William N. Eschmeyer of Caliofornia Academy of Sciences; Mr. Hiroshi Senou of Kinki University; Dr. Izumi Nakamura and Mr. Kosaku Yamaoka of Kyoto University; Drs. Takao Igarashi, Kunio Amaoka, Messrs. Mamoru Yabe and Eiichi Yamamoto of Hokkaido University; Dr. Robert R. Miller and Mr. Stuart G. Poss of the University of Michigan; Dr. Toru Takita of Nagasaki University; Dr. Ryoichi Arai of National Science Museum, Tokyo; Dr. Harald Ahnelt of Naturhistrisches Museum Wien; Drs. Roland J. McKay and J. Johnson of Queensland Museum; Dr. Marinus Boeseman of Rijksmuseum van Natuurlijke Historie, Leiden; Mr. Tetsuo Yoshino of University of the Ryukyus; Mrs. Margaret M. Smith and Dr. Phillip C. Heemstra of J.L.B. Smith Institute of Ichthyology, Rhodes University; Mr. Eiichi Fujii of Suruga Bay Marine Biology Research Group; Dr. Fujio Yasuda, Messrs. Akira Zama and Akihiko Yatsu of Tokyo University of Fisheries; Dr. Victor G. Springer of United States National Museum of Smithsonian Institution; Dr. Gerald R. Allen of Western Australian Museum; Dr. Masayoshi Hayashi of Yokosuka City Museum.

\section{REFERENCES}

Alcock, A. 1890. Natural history notes from H.M. Indian Marine Survey Steamer "Investigator", Commander, R.F. Hoskyn, R.N., commanding. -No.16. On the Bathybial fishes collected in the Bay of Bengal during the season 1889-90. Ann. Mag. Nat. Hist., Ser. 6, 6: 197-223.

Alcock, A. 1899. A descriptive catalogue of the Indian deep-sea fishes in the Indian Museum. Being a revised account of the deep-sea fishes collected by the Royal Indian Marine Survey Ship "Investigator', Calcutta, iii $+211 \mathrm{pp}$.

Arai, R. 1971. Record of the dragonet, Draculo mirabilis Snyder, from Hokkaido, Japan. Japan. J. Ichthyol., 18 (1): 33-35.

Barnard, K.H. 1927. A monograph of the marine fishes of South Africa, part 2. Ann. South African Mus., 21 (2): 419-1065.

Ben-Tuvia, A. 1978. Immigration of fishes through the Suez Canal. Fish. Bull., 76 (1): $249-255$.

Bianconi, G.G. 1859. Sepcimina zoologica Mosambicana quibus vel novae vel minus notae animalium species illustrantur. Fasciculus, 13: 1-363.

Bleeker, P. 1851. Over twee nieuwe soorten van Callionymus van den Indischen Archipel. Nat. Tijdschr. Ned. Ind., 1: 28-32.

Bleeker, P. 1852. Bijdrage tot de kennis der ichthyologische fauna van het eiland Banka. Nat. Tijdschr. Ned. Ind., 3: 443-460.

Bleeker, P. 1854. Faunae ichthyologicae japonicae species novae. Nat. Tijdschr. Ned. Ind., 6: 395-426.

Bleeker, P. 1858. Bijdrage tot de kennis der vischfauna van den Goram-Archipl. Nat. Tijdschr. Ned. Ind., 15: 197-218.

Bleeker, P. 1859. Vierde bijdrage tot de kennis der ichthyologische fauna van Japan. Act. Soc. Sc. Indo-Neerl., 5: 1-12.

Bleeker, P. 1879. Révision des espèces insulindiennes de la famille des Callionymơdes. Versl. Meded. Akad. Afd. Nat., 2nd Ser., 14: 79-107.

Blegvad, H. 1944. Fishes of the Iranian Gulf. Danish Scientific Investigations in Iran, Part 3: 1-247.

Bloch, M.E. and J.G. Schneider. 1801. Systema Ichthyologiae iconobus cx illustratum. Post obitum auctoris opus inchoatum absoluit, correxit, interpolavit Jo. Cottlob Schneider, Saxo. Berolini, $1 \mathrm{x}+584 \mathrm{pp}$. 
Böhlke, J.E. and C.C.G. Chaplin. 1968. Fishes of the Bahamas and adjacent tropical waters. Acad. Nat. Sci. Phila., Livingston, $x x x+772$ pp.

Böhlke, J. and D.M. Cohen. 1957. The eastern Pacific species of Callionymus. Copeia, 1957, no. 2: 159160.

Chang, H. 1951. On Callionymus reticulatus C. et V. and its distribution in European seas. J. Mar. Biol. Assoc. U.K., 30: 297-312.

Chu, Y. et al. 1962. Fishes of the South China Sea. Scientific Publ. Agency, Peking xxxxi+1184pp. (In Chinese).

Chu, Y., T. Tchang and C. Cheng. 1963. Fishes of the East China Sea. Scientific Publ. Agency, Peking, xxviii +642 pp. (In Chinese).

Davis, W. P. 1966. A review of the Dragonets (Pisces: Callionymidae) of the western Atlantic. Bull. Mar. Sci., 16(4): 834-862.

Davis, W.P. and C.R. Robins. 1966. The R/V Pillsbury deep-sea biological expedition to the Gulf of Guinea, 1964-65. 4. Pogonymus shango, a new Callionymid fish from quartz sand beaches of Nigeria, with notes on related species. Stud. Tropical Oceanogr. Miami, 4(1): 106-116.

Day, F. 1875. The fishes of India; being a natural history of the fishes known to inhabit the seas and fresh waters of India, Burma and Ceylon. London, $x x+778 \mathrm{pp}$.

de Beaufort, L.F. 1951. Family Callionymidae. pp. 50-81. In L.F. de Beaufort and W.M. Chapman: Fishes of the Indo-Australian Archipelago, Vol. 9, Percomorphi (concluded), Blennoidea, E.J. Brill, Leiden.

De Vis, G.W. 1883. Description of two new Queensland fishes. Proc. Linn. Soc. N.S.W., 1 (7): 620621.

Fowler, H.W. 1904. A collection of fishes from Sumatra. Jour. Acad. Nat. Sci. Philadelphia, Ser. 2., $12(4)$ : 496-560.

Fowler, H.W. 1925. Fishes of Guam, Hawaii, Samoa, and Tahiti. Bull. Bernice P. Bishop Mus., 22: $1-38$.

Fowler, H.W. 1928. The fishes of Oceania. Mem. Bernice P. Bishop Mus., 10: $\mathrm{i}-\mathrm{iii}+1-540$.

Fowler, H.W. 1931. Studies of Hong Kong Fishes, No. II. The Hong Kong Naturalist, 2(4) : $287-317$.

Fowler, H.W. 1934. The fishes of Oceania-supplement 2. Mem. Bernice P. Bishop Mus., 11 (6): 1-84.

Fowler, H.W. 1936. The marine fishes of West Africa based on the collection of the American Museum Congo expedition, 1909-1915. Bull. American Mus. Nat. Hist., 70(2): 607-1493.

Fowler, H.W. 1938a. A list of the fishes known from Malaya. Fisher. Bull., 1: 1-263.

Fowler, H.W. 1938b. The fishes of the George Vanderbilt south Pacific expedition, 1937. The Acad. Nat. Sci. Philadelphia, Monographs, 2: $i-v+1-349$.

Fowler, H.W. 1941. New fishes of the family Callionymidae, mostly Philippine, obtained by the United States Bureau of Fisheries Steamer "Albatross". Proc. U.S. Nat. Mus., 90 (3106): 1-31.

Fowler, H.W. 1943. Descriptions and figures of new fishes obtained in Philippine seas and adjacent waters by the United States Bureau of Fisheries Steamer "Albatross". Contributions to the biology of the Philippine archipelago and adjacent regions. Bull. U.S. Nat. Mus., 14 (2): i- iii $+53-91$.

Fowler, H.W. 1944. The fishes, results of the fifth George Vanderbilt expedition, 1941. Acad. Nat. Sci. Philadelphia, Monographs, 6: 57-583.

Fowler, H.W. 1946. A collection of fishes obtained in the Riukiu Islands by captain Ernest R. Tinkham A.U.S. Proc. Acad. Nat. Sci. Philadelphia, Vol. 98: 123-218.

Fowler, H.W. 1949. The fishes of Oceania-supplement 3. Mem. Bernice P. Bishop Museum, 12(2): $1-152$.

Fricke, R. 1980. Neue Fundorte und noch nicht beschriebene Geschlechtsunterschiede einiger Arten der Gattung Callionymus (Pisces, Perciformes, Callionymidae), mit Bemerkungen zur Systematik innerhalb dieser Gattung und Beschreibung einer neien Untergattung und einer neien Art. Est. Ann. Mus. Givico St. Nat. Genova, 83: 57-105.

Fricke, R. 1981a. On a new species of the family Callionymidae (Pisces, Perciformes, Callionymoidei), Callionymus stigmatopareius sp. nov. from Mozambique. J. Nat. Hist., 1981, 15: 161-167.

Fricke, R. 1981b. Diplogrammus (Climacogrammus) pygmaeus sp. nov., a new callionymid fish (Pisces, Perciformes, Callionymoidei) from the south Arabian coast, northwestern Indian Ocean. J. Nat. Hist., 15: 685-692. 
Fricke, R. 1981c. Revision of the genus Synchiropus (Teleostei: Callionymidae). Theses Zoologicae, 1. Verlag von J. Crame1, Braunschweig, $194 \mathrm{pp}$.

Fricke, R. 1981d. Two new and a rare species of the genus Callionymus (Teleostei: Callionymidae). Est. Ann. Mus. Givico St. Nat. Genova, 83: 387-400.

Fricke, R. 1981e. The kaianus-group of the genus Callionymus (Pisces: Callionymidae), with descriptions of six new species. Proc. Calif. Acad. Sci., 42(14): 349-377, figs. 1-18.

Garman, S. 1899. The fishes. Reports on an exploration off the west coasts of Mexico, central and south America, and off the Galapagos Islands, in charge of Alexander Agassiz, by the U.S. Fish Commission Steamer "Albatross", during 1891, Lieut. Commander Z.L. Tanner, U.S.N., Commanding. Mem. Mus. Comp. Zool. Harvard Coll., 24: 1-431.

Gilbert, C.H. 1905. The aquatic resources of the Hawailan Islands. Section II. -The deep-sea fishes. Bull. U.S. Fish Comm. for 1903, $23(2): i-x i+575-713$.

Gill, T.N. 1860. On the genus Callionymus of authors. Proc. Acad. Nat. Sci. Philad. 1859: 128-130.

Gill, T.N. 1865. On a new family type of fishes related to the Blennioids. Ann. Lyc. Nat. Hist. New York, 3: 141-144.

Giltay, L. 1933. Poissons. Mem. Mus. Roy. Hist. Nat. Belge. Hors ser., 5 (3): 1-129.

Goode, G.B. and T.H. Bean. 1895. Oceanic ichthyology. U.S. Nat. Mus. Spec. Bull., Washington, $\mathbf{x x x v}+553 \mathrm{pp}$.

Gosline, W.A. 1959. Four new species, a new genus and a new suborder of Hawaiian fishes. Paci. Sci. 13 (1): 67-77.

Gosline, W.A. and V.E. Brock. 1960. Hand book of Hawaiian fishes. Univ. Hawaii Press, Honolulu, $\mathrm{x}+372 \mathrm{pp}$.

Gray, J.E. 1835. Illustrations of Indian Zoology; chiefly selected from the collection of Major-General Hardwicke, F.R.S. Vol. 2. Adolphus Richter, London.

Gunther, A. 1861. Catalogue of the fishes in the British Museum, 3, London, xxv $+586 \mathrm{pp}$.

Gunther, A. 1864. Description of a new species of Callionymus from Australia. Ann. Mag. Nat. Hist., Ser. 3, (14): 197-198.

Gunther, A. 1871. Report on several collections of fishes recently obtained for the British Museum. Proc. Zool. Soc. London, 1871: 652-675.

Gunther, A. 1873. Report on a collection of fishes from China. Ann. Mag. Nat. Hist., Ser. 12, (4): 239_ 250.

Gunther, A. 1876. Andrew Garrett's Fishche der Sudsee II. Jour. Mus., Godeffroy, 4: i-ii+129-256.

Gunther, A. 1880. Report on the shore fishes procured during the Voyage of H.M.S. "Challenger" in the years 1873-76. Report on the Scientific Results of the Voyage of H.M.S. "Challenger" etc., Zoology, 1(6): 1-82.

Herre, A.W. 1927. A new genus and three new species of Philippine fishes. Philip. J. Sci. 32 (3): $413-419$.

Herre, A.W. 1928. Three new Philippine fishes. Philip. J. Sci., 35 (1): 31-35.

Herre, A.W. 1933. Twelve new Philippine fishes. Copeia, 1933, (1): 17--25.

Herre, A.W. 1934. Notes on fishes in the Zoological Museum of Stanford University. 1. The fishes of the Herre Philippine Expedition of 1931. Newspaper Enterprise, Hong Kong, 106 pp.

Herre, A.W. 1935. New fishes obtained by the Grane Pacific expedition. Field Mus. Nat. Hist. Pub. 335, Zool. Ser., 18(12): 383-438.

Herre, A.W. 1936. Notes on fishes in the Zollogical Museum of Stanford University, IV. A new catostomid from Mexico and a new Callionymid from Celebes and the Philippines. Proc. Biol. Soc. Washington, 49: 11-14.

Herre, A.W. 1936. Fishes of the Crane Pacific Expedition. Zoological Series, Field Mus. Nat. History founded by Marshall Field, 1893, 21 : 1-472.

Herre, A.W. 1940. Additions to the fish fauna of Malaya and notes on rare or little known Malayan and Bornean fishes. Bull. Raffles Mus., (16): 27-61.

Herre, A.W. 1953. Check list of Philippine fishes. Fish and Wildlife Service, U.S. Dept. Inst, Res. Rep., (20): 1-977.

Herre, A.W. and G.S. Myers. 1937. A contribution to the ichthyology of the Malay Peninsula. Bull. Raffles Mus., (13): 5-75. 
Houttuyn, M. 1782. Beschrijving van eenige Japansche visschen en andere zee-schepzelen. Verh. Holl. Maatsch. Wet. Haarlem, 20 (2): 1-18.

Hubbs, C.L. and K.F. Lagler. 1947. Fishes of the Great Lakes region. The University of Michigan Press, Ann Arbor, xv+213 pp.

Ishikawa, K. 1978. Record of the dragonet, Draculo mirabilis Snyder, in the shallow sea area of Ibaraki Prefecture, Japan. Bull. Fish. Exp. st. Ibaraki-ken, 22: 1-6.

Jatzow, R. and H. Lenz. 1898. Fische von Ost-Afrika, Madagașcar und Aldabra. Abr. Senckenberg. Naturf. Ges., Frankfurt a. -M., 21 : 497-531.

Johnson, C.R. 1971. Revision of the callionymid fishes referable to the genus Callionymus from Australian waters. Mem. Qd. Mus., (1.6): 103-140.

Johnson, C.R. 1972. The status of Callionymus phasis (Callionymidae) in Japanese Waters. Japan. J. Ichthyol., 19 (2) : 135.

Johnson, C.R. 1976. Callionymus russelli a new species of callionymid fish from Queensland, Australia. Zool. J. Linn. Soc., 58: 345-351.

Jordan, D.S. and B.W. Evermann. 1898. The fishes of North and Middle America. A descriptive catalogue of the species of fish-like vertebrates found in the waters of North America, north of the isthmus of Panama (Parts I-IV). Bull. U.S. Nat. Mus., (47): 1-3313.

Jordan, D.S., B.W. Evermann and H.W. Clark. 1930. Check list of the fishes and fishlike vertebrates of North and Middle America north of the northern boundary of Venezuela and Colombia. Rep. U.S. Comm. Fish. for 1928. (10): 1-670.

Jordan, D.S. and H.W. Fowler. 1903. A review of the dragonets (Callionymidae) and related fishes of the waters of Japan. Proc. U.S. Nat. Mus., 25 (1305) : 939-959.

Jordan, D.S. and C.L. Hubbs. 1925. Records of fishes obtained by David Star Jordan in Japan, 1922. Mem. Carnegie Mus., 10 (2) : 93-347.

Jordan, D.S. and E.K. Jordan. 1922. A list of the fishes of Hawaii, with notes and descriptions of new species. Mem. Carnegie Mus., 10(1): 1-92.

Jordan, D.S. and C.W. Metz. 1913. A catalogue of the fishes known from the waters of Korea. Mem. Carnegie Mus., 6(2): 1-65.

Jordan, D.S. and R.E. Richardson. 1908. Fishes from islands of the Philippine Archipelago. Bull. Bur. Fish., 27(1907): 233-287.

Jordan, D.S. and A. Seale. 1905. List of fishes collected in 1882-83 by Pierre Louis Jouy at Shanghai and Hongkong, China. Proc. U.S. Nat. Mus., 29(1433): 517-529.

Jordan, D.S. and A. Seale. 1906a. Descriptions of six new species of fishes from Japan. Proc. U.S. Nat. Mus., 30 (1445): 143-148.

Jordan, D.S. and A. Seale. 1906b. The fishes of Samoa. Description of the species found in the archipelago, with a provisional check-list of the fishes of Oceania. Bull. Bur. Fisher., 25(1905): 173-455.

Jordan, D.S. and A. Seale. 1907. Fishes of the islands of Luzon and Panay. Bull. Bur. Fisher., 24(1906): $1-48$.

Jordan, D.S. and J.O. Snyder. 1900. A list of fishes collected in Japan by Keinosuke Otaki, and by the United States Steamer Albatross, with descriptions of fourteen new species. Proc. U.S. Nat. Mus., xxiii: 335-380.

Jordan, D.S. and E.C. Starks. 1904. List of fishes dredged by the steamer "Albatross" off the coast of Japan in the summer of 1900, with descriptions of new species and a review of the Japanese Macrouridae. Bull. U.S. Fish Comm. for 1902, 22: 577-628.

Jordan, D.S. and E.C. Starks. 1905. On a collection of fishes made in Korea, by Pierre Louis Jouy, with descriptions of new species. Proc. U.S. Nat. Mus., 28(1391): 193-212.

Jordan, D.S., S. Tanaka and J.O. Snyder. 1913. A catalogue of the fishes of Japan. J. Coll. Sci., Imp. Univ. Tokyo, 33 (1): 1-497.

Jordan, D.S. and W.F. Thompson. 1914. Record of the fishes obtained in Japan in 1911. Mem. Carnegie Mus., 6(4): 205-313.

Kamohara, T. 1936. Two new deep-sea fishes from Japan. Annot. Zool. Japan, 15(4): 446-448.

Kamohara, T. 1952. Additions to the fish fauna of Prov. Tosa, Japan. Rept. Kochi Univ., Nat. Sci., (2) : 1-10. 
Kamohara, T. 1954. A list of fishes from the Tokara Islands, Kagoshima Prefecture, Japan. Pubı. Seto Mar. Biol. Lab., 3(3): 265-299.

Kobayashi, K. 1962. Ichthyofauna of Oshoro Bay and adjacent waters. Bull. Fac. Fish. Hokkaido Univ., 12(4): 253-264.

Kosaka, M. 1967. Zoogeographical Studies on the Demersal Fishes of Sendai Bay. J. Coll. Mar. Sci. \& Tech., Tokai Univ., (2) : 147-159. (In Japanese).

Kuronuma, K. and Y. Abe. 1972. Fishes of Kuwait. Kuwait Inst. Sci. Res., xiv+124 pp.

Li, S. 1966. New species and new Chinese records of Callionymid fishes from the south China Sea. Acta Zootaxonomica Sinica, 3(2): 167-176 (In Chinese with English summary).

Linnaeus, S. 1758. Nantes and Pisces pp. 230-338. In Systema Naturae, ed. X vol. 1.

Macleay, W. 1881. Descriptive catalogue of the fishes of Australia. Part II. Proc. Linn. Soc. N.S.W., (1) $5(4): 510-629$.

Marshall, T.C. 1965. Fishes of the Great Barrier Reef and coastal waters of Queensland. Livingston, Narberth, xvi + 566 pp.

Matsubara, K. 1955. Fish Morphology and hierarchy. pt. 1. Ishizaki Shoten, Tokyo, xi+789 pp. (In Japanese).

Maul, G.E. 1972. On a new species of the genus Callionymus from the Great Meteor Seamount (Percomorphi, Callionymoidea, Callionymidae). Bocagiana, Museu Municipal do Funchal, No. 30: 1- 7.

Maul, G.E. 1976. The fishes taken in bottom trawls by R.V. "Meteor" during the 1967 Seamounts Cruises in the Northeast Atlantic. „Meteor" Forsch-Ergebnisse, Reihe D, (22): 1-69.

McCann, C. 1972. Additions to the deep-sea fishes of New Zealand. New Zealand Journal of Marine and Freshwater Research, Wellington, 6(4): 619-640.

McCulloch, A.R. 1915. Report on some fishes obtained by the F.I.S. "Endeavour" on the coasts of Queensland, New South Wales, Victoria, Tasmania, south and south-western Australia. Biological Results of the Fishing Experiments carried on by the F.I.S. "Endeavour" 1909-14. 3(3): 97-170.

McCulloch, A.R. 1926. Report on some fishes obtained by the F.I.S. "Endeavour" on the coasts of Queensland, New South Wales, Victoria, Tasmania, south and south-western Australia. Biological Results of the Fishing Experiments carried on by the F.I.S. "Endeavour" 1909-14. 5(4): 157-216.

McCulloch, A.R. 1934. The fishes and fish-like animals of New South Wales. Third edition with supplement by Gilbert P. Whitley. Royal Zoological Society of New South Wales, Sydney, $104 \mathrm{pp}$.

Mees, G.F. 1963. The Callionymidae of Western Australia (Pisces). J. Roy. Soc. W. Aust. 46(3): 9399.

Metzelaar, J. 1919. Report on the fishes collected by Dr. J. Boeke, in the Dutch West Indies, 19041905, with comparative notes on marine fishes of tropical West Africa. Rapp. Viss. Zeeprod. Kolonie Curaçao, Gravenhage: 1-315.

Mori, T. 1952. Check list of the fishes of Korea. Mem. Hyogo Univ. Agri., 1(3): 1-228.

Mori, T. 1956. Fishes of San-in District including Oki Islands and its adjacent waters (Southern Japan Sea). Mem. Hyogo Univ. Agri. 2(3), Biol. Ser. No. 2: 1-62.

Munro, I.S.R. 1955. The marine and fresh water fishes of Ceylon. Dept. External Affairs, Camberra, xvi+352pp.

Munro, I.S.R. 1967. The fishes of New Guinea. Dept. Agri. Stock Fishr., Port Moresby, xxxvii + $650 \mathrm{pp}$.

Nakabo, T. 1977. A new dragonet, Callionymus draconis, taken from Kochi Prefecture, Japan. Japan J. Ichthyol., 24(2): 98-100.

Nakabo, T. 1979. A new and two rare species of the genus Callionymus (Callionymidae) from the western Indian Ocean. Japan. J. Ichthyol., 26(3): 231-237.

Nakabo, T. and A. Iwata. 1979. New record of Anaora tentaculata (Callionymidae) from the Ryukyu Islands, Japan. Japan. J. Ichthyol., 26(1): 89-93.

Ninni, A. 1877-78. Materiali per la fauna veneta. II. Genera Callionymus, L. Att. Ist, Veneto. Sc1., Ser. V, Tome 4: 1043-1057.

Ninni, E. 1934. Callionymus dei mari d'Europa. Notas y Resumenes, Publ. Instituto Espanol de Oceanografia, 85: 1-59. 
Nobre, A. 1935. Fauna marinha de Portugal, I, vertebrados (mamiferos, reptis e peixes), Pôrto, 1 xxxiv $+580 \mathrm{pp}$.

Norman, J.R. 1939. Fishes. John Murray exp. 1933-34 Sci. Rep., 7(1): 1-116.

Ochiai, A. 1963. Two dragonet fishes obtained from the tidal zone of the Amami Islands. Bull. Misaki Mar. Biol. Inst. Kyoto Univ., (4) : 63-74.

Ochiai, A., C. Araga and M. Nakajima. 1955. A review of the dragonets referable to the genus Callionymus found in the waters of Japan. Publ. Seto Mar. Biol. Lab., 5(1): 95-132.

Okada, Y. and H. Ikeda. 1937. Notes on the fishes of the Riu-Kiu Islands, II. Pomacentridae and Callionymidae. Bull. Biogeograph. Soc. Japan, 7(7): 67-95.

Ogilby, J.D. 1908. New or little known fishes in the Queensland Museum. Ann. Qld. Mus., 9: 3-41. Ogilby, J.D. 1910a. On new or insufficiently described fishes. Proc. Roy. Soc. Qld., 23: 1-55.

Ogilby, J.D. 1910b. On some new fishes from the Queensland coast. Proc. Roy. Soc. Qld., 23: 85-139.

Ogilby, J.D. 1911. Description of new or insufficiently described fishes from Queensland waters. Ann. Qld. Mus., 10:36-58.

Pallas, P.S. 1770. Spicilegia zoologica, 1(8): 3-54.

Parr, A.E. 1930. Teleostean shore and shallow-water fishes from the Bahamas and Turks Islands. Bull. Bingham. Oceanogr. Coll., 3(4) : 1-148.

Peters, W.C.H. 1855. Ubersicht der in Mozambique beobachteten Seefische. Monatsher Akad. Wiss. Berlin, 1855; 428-466.

Pfeffer, G.J. 1893. Ostafrikanische Fische gesammelt von Herru Dr. F. Stuhlmann im Jahre 1888 und 1889. Jahrb. Wiss. Austalt Hamburg, 10: 131-177.

Playfair, R.L. 1866. Acanthopterygii. pp. 1-80. In R.L. Playfair and A.G. Gunther: The fishes of Zanzibar. John van Vorrst. London.

Poll, M. 1949. Poissons, resultats scientifuques des croisières du Navire-Ecole Belge "Mercator", 4: 173-269.

Rao, V.V., 1975. Pogonymus goslinei, sp. nov. (Pisces: Callionymidae) from Ennore estuary, Madras. Matsya 1: 27-29.

Regan, C.T. 1905a. On fishes from Persian Gulf, the sea of Oman, and Karachi, collected by Mr. F.W. Townsend. J. Bombay Nat. Hist. Soc., 16(2): 318-333.

Regan, C.T. 1905b. On a collection of fishes from the inland sea of Japan made by Mr. Gordon Smith. Ann. Mag. Nat. Hist. Ser. 7, 15: 1-26.

Regan, C.T. 1908. Report on the marine fishes collected by Mr. J. Stanley Gardiner in the Indian Ocean. Trans. Linn. Soc. London, Zool. 2nd Ser., 12(3): 217-255.

Richardson, J. 1844, Ichthyology, pp. 50-150. In the zoology of the voyage of H.M.S. "Sulphur", under the command of Captain Sir Edward Belcher, during the years 1836-42.

Richardson, J. 1846. Report on the ichthyology of the seas of China and Japan. Rep. British Assoc. Adv. Sci. for 1845: 187-320.

Richardson, J. and J.E. Gray. 1844. Fishes, pp. viii +139. In the zoology of the voyage of H.M.S. "Erebus and Terror", under the command of Capt. Sir. J.C. Ross during 1839-43. Vol. 2, London.

Schultz, L.P. 1943. Fishes of the Phoenix and Samoau islands collected in 1939 during the expedition of the U.S.S. "Bushnell", Smith. Insti. U.S. Nat. Mus. Bull., 180: i-v+1-316.

Schultz, L.P. 1960. Family Callionymidae, pp. 397-413. In L.P. Schultz and collaborators: Fishes of the Marshall and Marianas Islands, Vol. 2, U.S. Nat. Mus. Bull., 202(2).

Schultz, L.P. and L.P. Woods. 1948. A new name for Synchiropus altivelis Regan, with a key to the genera of the fish family Callionymidae. J. Wash. Acad. Sci., 38(12): 419-420.

Seale, A. 1909. New species of Philippine fishes. Phil. J. Sci., 4(6): 491-543.

Seale, A. 1914. Fishes of Hongkong. Phil. J. Sci., 9(1): 59-81.

Seale, A. 1940. Report on fishes from Allan Hancock expeditions in the California Academy of Sciences. Allan Hancock Pacific expeditions 9(1): 1-46.

Smith, J.L.B. 1949. The sea fishes of Africa. Central News Agency, South Africa, xviii +550 pp.

Smith, J.L.B. 1963. Fishes of the families Draconettidae and Callionymidae from the Red Sea and the western Indian Ocean. Rhodes Univ. Ichthyol. Bull. 28: 547-564.

Smith, J.L.B. 1965. An interesting new callionymid fish from Madagascar and the first record of a clingfish from there. Ann. Mag. Nat. Hist. Ser. 13, 8: 321-324. 
Snyder, J.O. 1911. Descriptions of new genera and species of fishes from Japan and the Riu Kiu Islands. Proc. U.S. Nat. Mus., 40(1836): 525-549.

Snyder, J.O. 1912. Japanese shore fishes collected by the United States Bureau of Fisheries steamer "Albatross" expedition of 1906. Proc. U.S. Nat. Mus. 42(1909): 399-450.

Suvatti, C. 1936. Index to fishes of Siam. Bureau of Fisheries, Bankok, F+226 pp.

Suwardji. 196.5. Notes on the genus Callionymus (Pisces, Callionymidae) mostly from Indonesian Waters with the description of three new species and a new subspecies. Vidensk. Medd. Dansk. Naturhist. Foren., 128: 303-323.

Takegawa, Y. and H. Morino. 1970. Fishes from Wakasa Bay, Japan Sea. Publ. Seto Mar. Biol. Lab., $17(6)$ : 373-392.

Takita, T. and E. Okamoto. 1979. Spawning behavior of the two dragonets, Callionymus flagris and $C$. richardsoni, in the aquarium. Japan. J. Ichthyol., 26(3): 282-288. (In Japanese).

Tanaka, S. 1917. Eleven new species of fishes from Japan. Zool. Mag., 29(339): 7-12. (In Japanese).

Tanaka, S. 1928. Figures and Descriptions of the Fishes of Japan, Vol. 42: 809-830.

Tchang, T., G. Cheng, P. Cheng, S. Li, W. Cheng and W. Wang. 1955. Fishes of the Yellow Sea and Pohai, China. Scientific Publ. Agency, Peking, 362 pp. (In Chinese).

Temminck, C.J. and H. Schlegel. 1845. Pisces, pp. 113-172. In Siebold's Fauna Japonica, pt. 7-9. Leiden.

Tortonese, E. 1964. The main biological features and problems of the Mediterranean fish fauna. Copeia, 1964, no. 1: 98-107.

Ueno, T. 1971. List of the marine fishes from the waters of Hokkaido and its adjacent regions. Sri. Rep. Hokkaido Fish. Exp. Sta., (13): 61-102. (In Japanese with English summary).

Valenciennes, A. 1837. Historie naturelle des poissons. 12. pp. 197-232. In Cuvier, G. and A. Valenciennes: Histoire naturelle des Poissons. F.G. Leurault, Paris.

Weber, M. 1913. Die Fische der Siboga-Expedition. Siboga-Expeditie 57. E.J. Brill, Leiden, xii + $710 \mathrm{pp}$.

Wheeler, A. 1969. The fishes of the British Isles \& N.W. Europe. Macmillan, London, xviii +613 pp.

Wheeler, A. 1973. Callionymidae, pp. 516-518. In Clofnam I, check-list of the fishes of the northeastern Atlantic and of the Mediterranean edited by J.C. Hureau and Th. Monod. Unesco, Paris.

Wheeler, A. 1975. Fishes of the world, an illustrated dictionary. Macmillan Publishing, New York, xvi+366 pp.

Whitley, G.P. 1928. Studies in Ichthyology, No. 2. Rec. Aust. Mus. 16(4): 211-239.

Whitley, G.P. 1929. Studies in Ichthyology, No. 3. Rec. Aust. Mus. 17: 101-143.

Whitley, G.P. 1931a. New names for Australian fishes. Aust. Zool., 6(4): 310-314.

Whitley, G.P. 1931b. Studies in Ichthyology, No. 4. Rec. Aust. Mus., 18: 96-133.

Whitley, G.P. 1934. Supplement to the check-list of the fishes of New South Wales, pp. 1-12. In A.R. McCulloch: The Fishes and fish-like animals of New South Wales. 3rd ed., Royal Zoological Society of New South Wales, Syndey.

Whitley, G.P. 1944. New sharks and fishes from Western Australia. Aust. Zool. 10: 252-273.

Whitley, G.P. 1947. New sharks and fishes from Western Australia, Part 3. Aust. Zool. 11 : 129-150.

Whitley, G.P. 1948. New sharks and fishes from Western Australia, Part 4. Aust. Zool., 11(3): 259 279.

Yoshino, T. 1976. Five unrecorded fishes from Japan, collected from Sesoko Island, Okinawa. Biol. Mag. Okinawa (14): 33-40.

Yoshino, T., S. Nishijima and S. Shinohara. 1975. Catalogue of fishes of the Ryukyu Islands. Bull. Science \& Engincering Div., Univ. of the Ryukyus. (Math \& Nat. Sci., 20) : 61-118. (In Japanese). 